\title{
The design, fabrication, and photocatalytic utility of nanostructured semiconductors: focus on $\mathrm{TiO}_{2}$-based nanostructures
}

This article was published in the following Dove Press journal:

Nanotechnology, Science and Applications

I4 February 2011

Number of times this article has been viewed

\author{
Arghya Narayan Banerjee \\ School of Mechanical Engineering, \\ Yeungnam University, Gyeongsan, \\ South Korea
}

\begin{abstract}
Recent advances in basic fabrication techniques of $\mathrm{TiO}_{2}$-based nanomaterials such as nanoparticles, nanowires, nanoplatelets, and both physical- and solution-based techniques have been adopted by various research groups around the world. Our research focus has been mainly on various deposition parameters used for fabricating nanostructured materials, including $\mathrm{TiO}_{2}$-organic/inorganic nanocomposite materials. Technically, $\mathrm{TiO}_{2}$ shows relatively high reactivity under ultraviolet light, the energy of which exceeds the band gap of $\mathrm{TiO}_{2}$. The development of photocatalysts exhibiting high reactivity under visible light allows the main part of the solar spectrum to be used. Visible light-activated $\mathrm{TiO}_{2}$ could be prepared by doping or sensitizing. As far as doping of $\mathrm{TiO}_{2}$ is concerned, in obtaining tailored material with improved properties, metal and nonmetal doping has been performed in the context of improved photoactivity. Nonmetal doping seems to be more promising than metal doping. $\mathrm{TiO}_{2}$ represents an effective photocatalyst for water and air purification and for self-cleaning surfaces. Additionally, it can be used as an antibacterial agent because of its strong oxidation activity and superhydrophilicity. Therefore, applications of $\mathrm{TiO}_{2}$ in terms of photocatalytic activities are discussed here. The basic mechanisms of the photoactivities of $\mathrm{TiO}_{2}$ and nanostructures are considered alongside band structure engineering and surface modification in nanostructured $\mathrm{TiO}_{2}$ in the context of doping. The article reviews the basic structural, optical, and electrical properties of $\mathrm{TiO}_{2}$, followed by detailed fabrication techniques of 0-, 1-, and quasi-2-dimensional $\mathrm{TiO}_{2}$ nanomaterials. Applications and future directions of nanostructured $\mathrm{TiO}_{2}$ are considered in the context of various photoinduced phenomena such as hydrogen production, electricity generation via dye-sensitized solar cells, photokilling and self-cleaning effect, photo-oxidation of organic pollutant, wastewater management, and organic synthesis.

Keywords: $\mathrm{TiO}_{2}$ nanostructure, fabrication techniques, doping in $\mathrm{TiO}_{2}, \mathrm{TiO}_{2}$-assisted photoactivity, solar hydrogen, $\mathrm{TiO}_{2}$-based dye-sensitized solar cells, $\mathrm{TiO}_{2}$ self-cleaning, organic synthesis
\end{abstract}

\section{Introduction}

In the last century, scientists have made rapid and significant advances in the field of semiconductor physics. Semiconducting materials have been the subject of great interest due to their numerous practical applications, and they provide fundamental insights into the electronic processes involved. Similarly, material processing has become an increasingly important research field. Many new materials and devices, which possess specific properties for special purposes, have now become available, but material limitations are often the major deterrent to the achievement of new technological advances. Material scientists are now particularly interested in developing materials which maintain their required properties in extreme environments.
Correspondence: Arghya Narayan Banerjee 212 School of Mechanical Engineering, Yeungnam University, Gyeongsan 712-749, South Korea

Tel +82538102453

Fax +82538102062

Email arghya75@gmail.com 
After the pioneering works of Efros and Efros ${ }^{1}$ and Brus ${ }^{2}$ on the size quantization effect in semiconductor nanoparticles, research on nanostructured materials has generated great interest in the scientific community. Tremendous opportunities in science and technology are now possible because of the new properties exhibited by these materials and the challenging problems in theoretical physics associated with the new properties. $^{3-6}$ In general, 'nanotechnology' is the engineering of functional systems at the molecular scale. In its original sense, nanotechnology refers to the projected ability to construct items from the bottom up, using techniques and tools being developed today to make complete, high-performance products. As nanotechnology became an accepted concept, the meaning of the word shifted to encompass the simpler kinds of nanometer-scale technology. Formulation of a road map for development of this kind of nanotechnology is now an objective of a broadly based technology road map project of various leading nanotechnology research groups and institutes in the world. According to the US National Nanotechnology Initiative, the road map of nanotechnology can be divided into four generations (Figure 1). The first era is that of passive nanostructures, which are materials designed to perform one task. The second phase introduces active nanostructures for multitasking; for example, diodes, transistors, actuators, drug-delivery devices, and sensors. We are entering the third generation, which will feature nanosystems with thousands of interacting components. In future, we may expect the development of integrated nanosystems functioning much like a mammalian cell with hierarchical systems within systems.

The optical properties of nanocrystals are related to their size and surface chemistry and drastically differ from those of bulk materials. Preparation and study of high-quality quantum dots, nanobelts, and nanowires have been reported widely. ${ }^{7-9}$ Achievements in recent years have focused nanomaterials research on the applications in electrical and optoelectronics devices. ${ }^{10-12}$ Within the class of inorganic materials, oxide-based compounds show the most diverse range of properties. The electronic properties of these materials mainly depend on the nature of cationoxygen bonding, which is explained either by solid-state band theory or by ionic bonding concepts from solid-state chemistry or by combining aspects of both approaches. This interplay between localized and itinerant character

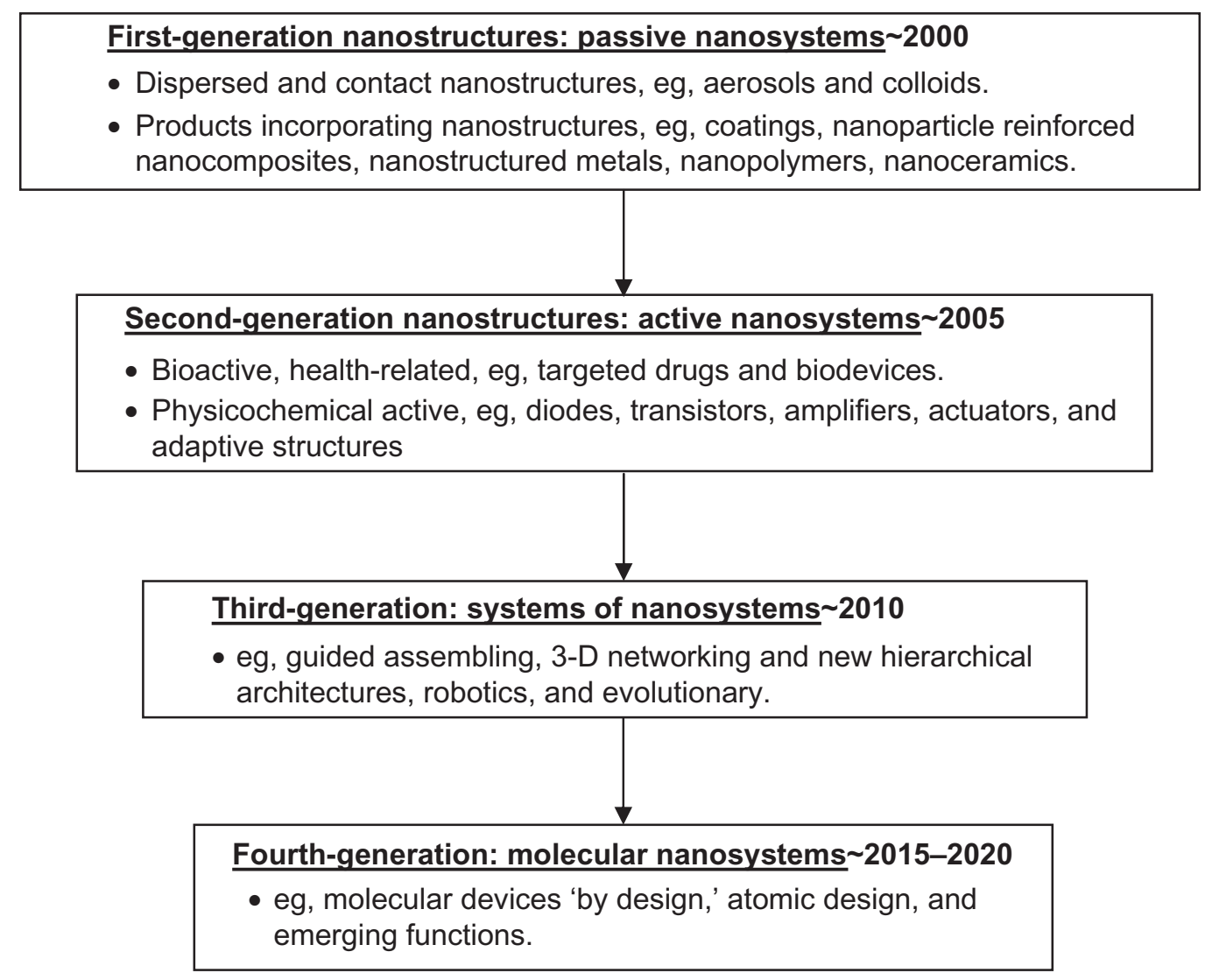

Figure I Road map to nanotechnology.

Reproduced with permission from the US National Nanotechnology Initiative report. 
yields a wide range of electronic properties of metal oxides. For example, a closed-shell compound such as $\mathrm{Al}_{2} \mathrm{O}_{3}$ is an insulator displaying large band gaps. In many cases, these insulators can serve as effective host materials for efficient luminescence when doped with rare earth or transition metal cations. On the other hand, for closed-shell oxides based on cations with relatively high electronegativity, such as in $\mathrm{ZnO}$ and $\mathrm{SnO}_{2}$, the more covalent nature of bonding yields semiconductors with relatively high carrier mobilities. Electronic oxides containing transition metal cations can yield high conductivity materials, such as $\mathrm{SrRuO}_{3}$, or even superconductors, as with $\mathrm{YBa}_{2} \mathrm{Cu}_{3} \mathrm{O}_{7}$. Collective phenomenon involving electric dipole interactions in insulators yields ferroelectrics such as $\mathrm{BaTiO}_{3}$. Unpaired electron spin in some oxides results in ferromagnetism, as in $\mathrm{CrO}_{2}$, or ferrimagnetism, as in $\mathrm{Fe}_{3} \mathrm{O}_{4}$. In addition, many oxides display interesting metal-insulator transitions that are dependent on temperature (eg, $\left.\mathrm{V}_{2} \mathrm{O}_{3}\right)$, pressure (eg, $\mathrm{NiO}$ ), or magnetic fields (eg, $\left.(\mathrm{La}, \mathrm{Sr}) \mathrm{MnO}_{3}\right) \cdot{ }^{13-19}$ Because of their fundamental properties and obvious utility in applications, significant efforts have been invested in the growth of oxides as epitaxial thin films. Various classes of metal oxides are schematically represented in Figure 2.

Among these oxides, materials scientists are overwhelmingly interested in the fundamental aspects and applications of semiconducting wide band-gap oxide materials. These types of materials show a wide range of electrical and optical properties. They can be transparent in the visible and infrared (IR) range and can be found in insulators as well as semiconductors. Among these wide-gap oxide materials, we will focus mainly on nanostructured titanium dioxide $\left(\mathrm{TiO}_{2}\right)$, also known as titanium (IV) oxide or titania, which is a naturally occurring oxide of titanium. Because of its wide range of applications, from paint to sunscreen to food coloring to photocatalyst, hydrogen production, storage medium, sensors, solar cells, and various biological and health-related applications, this technologically important material is the

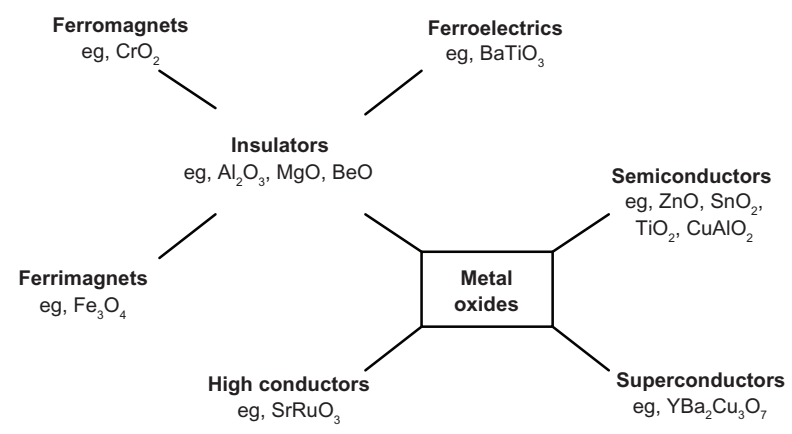

Figure 2 Classifications of metal oxides. subject of ongoing research and development in design, syntheses, and applications.

\section{Properties of $\mathrm{TiO}_{2}$ Overview}

$\mathrm{TiO}_{2}$ is a chemically stable, nontoxic, biocompatible, inexpensive material with very high dielectric constant and interesting photocatalytic activities. It is a wide-gap semiconductor, and depending on its chemical composition, it shows a large range of electrical conductivity. In general, $\mathrm{TiO}_{2}$ has two stable crystalline structures: anatase and rutile. ${ }^{20}$ Usually, natural rutile crystals are impure, and, therefore, early investigations were limited to ceramic samples only, but later (around 1950s), a colorless, large, single crystal of synthetic rutile was grown by the Boule technique. ${ }^{21,22}$ Thereafter, most of the research was done on the electro-optical characterization and defect chemistry of rutile single crystals. ${ }^{21-26}$ Stoichiometry of the rutile $\mathrm{TiO}_{2}$ is highly dependent on its deposition parameters, especially on annealing conditions and atmosphere. ${ }^{24,27-30}$ The charge transport phenomenon in rutile is described by small polaron model. ${ }^{31-34}$ Earlier, it was assumed that the properties of anatase would be similar to those of rutile ${ }^{35}$ until a new solar cell concept was reported using anatase, which cannot be realized by rutile structure. ${ }^{36}$ With the possibility of growing synthetic anatase single crystals, ${ }^{37}$ considerable research to systematically investigate the electronic and optical properties of anatase $\mathrm{TiO}_{2}$ has begun. . $^{35,38-43}$

In general, titanium metal oxidizes in ambient conditions and a thin layer of native oxide grows on the surface. This surface oxide layer is about $4 \mathrm{~nm}$ thick and protects the metal from further oxidation and consists mostly of rutile and anatase $\mathrm{TiO}_{2}$, but very small amounts of $\mathrm{Ti}_{2} \mathrm{O}_{3}$ and $\mathrm{TiO}$ can also be found. ${ }^{44}$ This native oxide layer not only passivates the surface, but also resists corrosion from a harsh environment and is useful as an implant material in orthopedic and dental applications ${ }^{44} \mathrm{TiO}_{2}$ powder is commonly used as a pigment in paints, coatings, plastics, papers, inks, fibers, nutrients, toothpaste, and cosmetics. ${ }^{45,46}$ Due to its high refractive index, it has found important applications in antireflection coatings, narrow-band filters, and optical waveguides. ${ }^{47-52}$ Often, the properties can be tuned by creating multilayers of $\mathrm{TiO}_{2}$ and $\mathrm{SiO}_{2}^{53}$ in a stacked conformation, where the high refractive index of $\mathrm{TiO}_{2}$ is combined with the low refractive index of $\mathrm{SiO}_{2}$ to show interesting optical properties. $\mathrm{TiO}_{2}$ has also been used as $\mathrm{NO}_{x}$, oxygen, and hydrocarbon sensors. ${ }^{54-58}$ The catalytic activities of $\mathrm{TiO}_{2}$ surface under visible irradiation led to interesting applications in water purification 
(by dissociating pollutants in dissolved organic molecules), water decomposition for hydrogen production, ${ }^{59-65}$ dyesensitized solar cells (DSSCs) and electrochromic devices, ${ }^{36,66,67}$ solid-state photovoltaic solar cells, ${ }^{68-70}$ photoelectrochemical anticorrosion coatings, self-cleaning properties, ${ }^{71}$ and superhydrophilicity. ${ }^{72}$ Moreover, because it is a highly dielectric material, there are interesting electronic applications for rutile $\mathrm{TiO}_{2} \cdot{ }^{73}$ Local oxidation of titanium thin films by scanning probe microscopes yields a convenient lithographic patterning technique, which does not require any etching, ${ }^{74}$ thus creating microelectronic elements. ${ }^{75}$ Silver (Ag)-incorporated $\mathrm{TiO}_{2}$ showed multicolor photochromism under visible irradiation. ${ }^{76}$ Some new applications can be possible with this material, such as rewritable color copy paper or high-density multiwavelength optical memories. ${ }^{77}$ Rutile is preferred to anatase for optical applications because of its higher refractive index. On the other hand, anatase is prefered for all the applications related to photocatalytic activity, gas sensing, and solar cells, due to its higher mobility and its catalytic properties. ${ }^{36,55,61}$ Fabrication techniques of doped or undoped $\mathrm{TiO}_{2}$ thin films with a wide variety of properties and morphologies include both wet-chemical and vacuum-based physical techniques. An overview of the available techniques can be found in in the literature. ${ }^{78-83} \mathrm{It}$ is noteworthy that the terms ' $\mathrm{TiO}_{2}$ ' and 'titanium dioxide' are generally used for slightly substoichiometric films of the composition $\mathrm{TiO}_{2-x}$ with $x<0.1$, which exists in a mixture of rutile, anatase, and amorphous crystalline phases.

\section{Crystal structure of $\mathrm{TiO}_{2}$}

As mentioned earlier, naturally occurring $\mathrm{TiO}_{2}$ crystal has three common polymorphs: rutile (tetragonal), anatase (tetragonal), and brookite (orthorhombic), ${ }^{17,84,85}$ along with some less common structures like $\mathrm{TiO}_{2}$ II (columbite), ${ }^{86}$ $\mathrm{TiO}_{2}$ III (baddeleyite), ${ }^{87,88} \mathrm{TiO}_{2}(\mathrm{H})$ (hollandite), ${ }^{89} \mathrm{TiO}_{2}$ (R) (ramsdellite), ${ }^{90}$ and $\mathrm{TiO}_{2}$ (B) (monoclinic) ${ }^{91}$ many of which occur only at very particular conditions. Among these structures, rutile is the most stable phase, ${ }^{92}$ whereas anatase is metastable at room temperature and transforms irreversibly into rutile upon heating above a threshold temperature around $1000^{\circ} \mathrm{C}$ (which is in atmospheric conditions, but the threshold temperature can vary from $400^{\circ} \mathrm{C}$ to $1200^{\circ} \mathrm{C}$ depending on the grain size, ambient conditions, and impurities).$^{93}$ Natural rutile crystals exhibit predominantly (110) surface, ${ }^{17}$ which is considered to be the most stable surface of stoichiometric rutile, ${ }^{94,95}$ whereas anatase is the most stable with (101) surface.$^{83}$ Figure 3 shows the
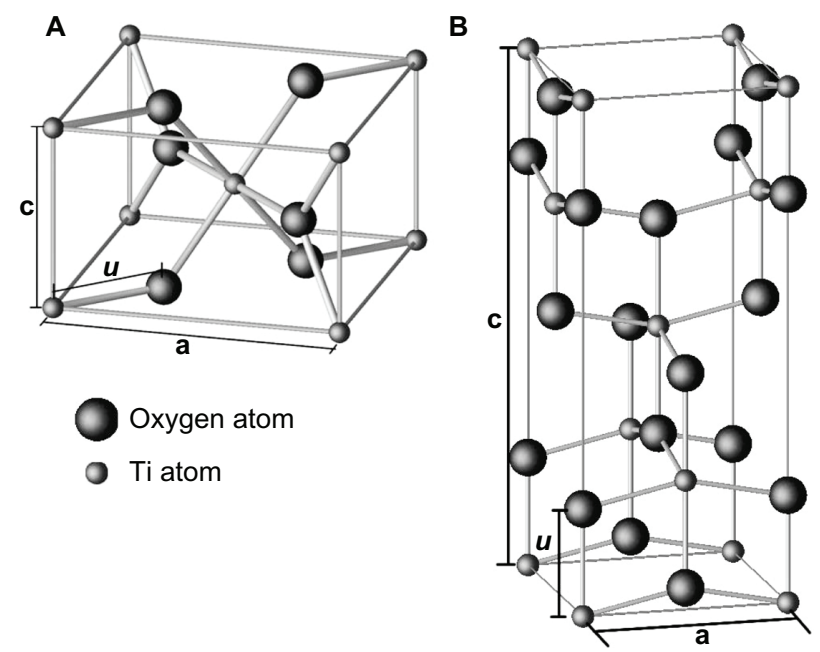

Figure 3 Crystallographic unit cell structure of $\mathrm{TiO}_{2}$ with $\mathbf{A}$ ) rutile and $\mathbf{B}$ ) anatase structures.

Copyright (c) 2003, Cangiani. Adapted with permission from Cangiani G. Ab Initio Study of the Properties of $\mathrm{TiO}_{2}$ Rutile and Anatase Polytypes. Lausanne, France: Faculté des sciences de base, Ecole polytechnique fédérale de Lausanne EPFL; 2003.

schematics of the unit cells of the $\mathrm{TiO}_{2}$ crystal structures, and Table 1 shows the unit cell parameters (at room temperature). The rutile unit cell contains two Ti atoms (at $[0,0,0]$ and $[1 / 2,1 / 2,1 / 2])$ positions, respectively) and four oxygen atoms (that form a distorted octahedron around Ti). The anatase unit cells contains four Ti atoms (at $[0,0,0],[1 / 2,1 / 2,1 / 2],[0$, $1 / 2,1 / 4]$, and $[-1 / 2,0,-1 / 4]$ ) and eight oxygen atoms (that form a distorted $\mathrm{TiO}_{6}$ octahedron around each Ti cation). ${ }^{82,96}$ The $\mathrm{TiO}_{6}$ octahedra constitute the basic building units for the various polymorphic structures of $\mathrm{TiO}_{2}$ and differ from each other by the arrangement and the distortion of the octahedra (Figure 4). In the rutile crystal, each octahedron is connected to two edge-sharing and eight corner-sharing neighboring octahedra, in which the edge-shared octahedra are aligned along the (001) surface direction. ${ }^{21}$ In the case of anatase, there are four edge-sharing neighbors, which are aligned along the (100) and (010) surface direction forming zigzag double chains perpendicular to the $c$-axis, thus creating open channels parallel to the $c$-axis in rutile and perpendicular to the $c$-axis in anatase. ${ }^{82,94}$

Phase diagram of the oxides of titanium shows that by varying the oxygen content from 0 to 2 oxygen per titanium atom, the main phases that can be found at room temperature are $\mathrm{Ti}, \mathrm{Ti}_{2} \mathrm{O}, \mathrm{TiO}, \mathrm{Ti}_{2} \mathrm{O}_{3}, \mathrm{Ti}_{3} \mathrm{O}_{5}$, and finally $\mathrm{TiO}_{2} \cdot{ }^{97}$ Additionally, a series of $\mathrm{Ti}_{\mathrm{n}} \mathrm{O}_{2 \mathrm{n}-1}$ (with $\mathrm{n} \geq 4$ ) phases can be found in between $\mathrm{Ti}_{3} \mathrm{O}_{5}$ and $\mathrm{TiO}_{2}$ phase, which is called the Magnéli series of homologous compounds, ${ }^{30,98}$ where physical properties are changed dramatically, ranging from metallic 
Table I Comparison of the structural, optical, and electrical properties of rutile and anatase

\begin{tabular}{|c|c|c|c|c|}
\hline \multirow[t]{2}{*}{ Polymorphs } & \multicolumn{2}{|l|}{ Rutile } & \multicolumn{2}{|l|}{ Anatase } \\
\hline & $\| c$ & $\perp c$ & $\| c$ & $\perp c$ \\
\hline \multirow[t]{2}{*}{ Crystal structure } & \multicolumn{2}{|c|}{ Tetragonal } & \multicolumn{2}{|c|}{ Tetragonal } \\
\hline & $c=2.9587 \AA[470]$ & $a=4.5937 \AA ̊ \AA 470]$ & $c=9.5146 \AA[93]$ & $a=3.7842 \AA[93]$ \\
\hline Space group & \multicolumn{2}{|c|}{$\mathrm{P}_{2} / \mathrm{mnm}(136)[84]$} & \multicolumn{2}{|c|}{14, amd (14I) [84] } \\
\hline Most stable state & \multicolumn{2}{|c|}{ (I I0) [94] } & \multicolumn{2}{|c|}{$(101)[102]$} \\
\hline Density & \multicolumn{2}{|c|}{$4.25 \mathrm{~g} / \mathrm{cc}[84]$} & \multicolumn{2}{|c|}{$3.89 \mathrm{~g} / \mathrm{cc}[84]$} \\
\hline Band gap at $10 \mathrm{~K}$ & $3.05 \mathrm{I} \mathrm{eV}[47 \mathrm{I}, 472]$ & $3.035 \mathrm{eV}[47 \mathrm{I}, 472]$ & $3.46 \mathrm{eV}[35]$ & $3.42 \mathrm{eV}[35]$ \\
\hline Spectral dependence & $E^{1 / 2}[35]$ & $E^{3 / 2}[35]$ & Urbach [40] & \\
\hline Nature of gap & Indirect $[471,472]$ & Direct $[47 I, 472]$ & Indirect [35] & Direct [35] \\
\hline \multicolumn{5}{|l|}{$\left(\varepsilon_{0}\right.$, in $\mathrm{MHz}$ range $)$} \\
\hline $\begin{array}{l}\text { High frequency dielelectric } \\
\text { constant, } \varepsilon_{\infty}(\lambda=600 \mathrm{~nm})\end{array}$ & $8.35[103]$ & $6.76[103]$ & $6.25[4 I]$ & $6.50[4 I]$ \\
\hline $\begin{array}{l}\text { Refractive index } \\
\text { (at } \lambda=600 \mathrm{~nm} \text { ) }\end{array}$ & $2.89[103]$ & $2.60[103]$ & $2.50[4 I]$ & $2.55[4 I]$ \\
\hline $\begin{array}{l}\text { Nature of conductivity at } \\
\text { room temperature (undoped) }\end{array}$ & \multicolumn{4}{|c|}{ n-Type semiconductor } \\
\hline Mott transition & \multicolumn{2}{|c|}{ Not observed [II8] } & \multicolumn{2}{|c|}{ Observed [35] } \\
\hline Room temperature mobility & \multicolumn{2}{|c|}{$0.1-1 \mathrm{~cm}^{2} / \mathrm{vs}[22,8 \mathrm{I}]$} & \multicolumn{2}{|c|}{$15 \mathrm{~cm}^{2} / \mathrm{vs}[35, \mathrm{II} 2]$} \\
\hline in crystal & $0.6-1.5 \mathrm{~cm}^{2} / \mathrm{vs}[476]$ & $\begin{array}{l}0.0 \mathrm{I} \mathrm{cm} / \mathrm{vs} \text { (high impurity } \\
\text { concentration) }[8 \mathrm{I}]\end{array}$ & & \\
\hline $\begin{array}{l}\text { Room temperature mobility in } \\
\text { polycrystalline thin film }\end{array}$ & \multicolumn{2}{|c|}{$0.1 \mathrm{~cm}^{2} / \mathrm{vs}[22,38]$ CUA } & \multicolumn{2}{|l|}{$0.1-4 \mathrm{~cm}^{2} / \mathrm{vs}[35]$} \\
\hline Electron effective mass & & & $\sim 1 \mathrm{~m}_{\mathrm{e}}[35]$ & \\
\hline
\end{tabular}

Copyright (C) 2003, Springer. Adapted with permission from Springer S. Free carriers in nanocrystalline titanium dioxide thin films. Ecole polytechnique fédérale de Lausanne EPFL; 2004; Lausanne, France; Thèse no 2934. For further properties please refer Diebold U. The surface science of titanium dioxide. Surf Sci Rep. 2003;48(5-8):53-229.
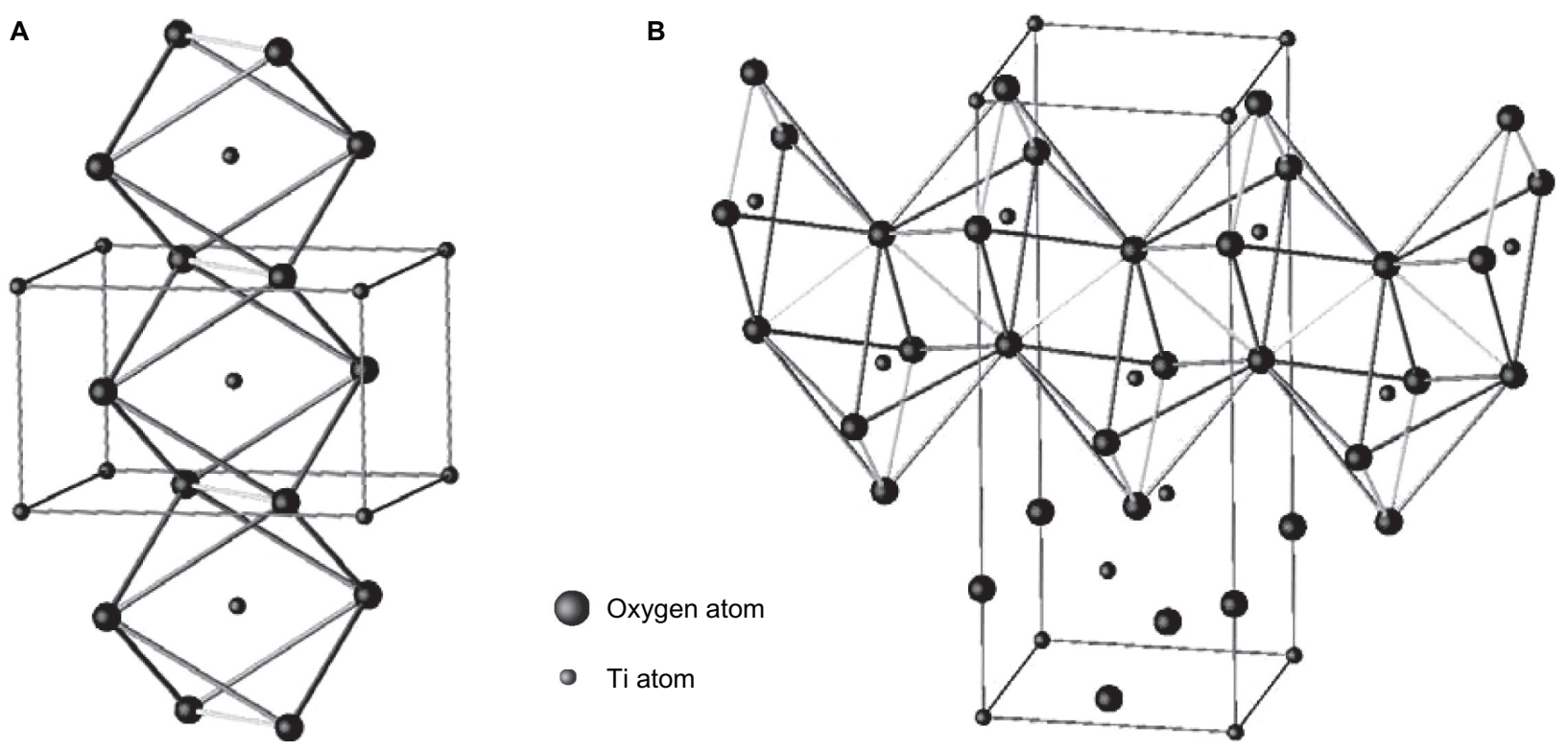

Figure 4 Arrangement of $\mathrm{TiO}_{6}$ octahedra in relation to the unit cells in $\mathbf{A}$ ) rutile and $\mathbf{B}$ ) anatase. Only one chain is shown for each structure. Highlighted bonds are the O-O bonds.

Copyright @ 2003, Cangiani. Adapted with permission from Cangiani G. Ab Initio Study of the Properties of TiO ${ }_{2}$ Rutile and Anatase Polytypes. Lausanne, France: Faculté des sciences de base, Ecole polytechnique fédérale de Lausanne EPFL; 2003. 
to insulating depending on $\mathrm{n}$. The formation of such reduced oxide phases can be described in terms of the elimination of a plane of oxygen atoms. ${ }^{30}$ Magnéli phases with $n$ up to about $38\left(\mathrm{TiO}_{1.974}\right)^{82}$ and $61\left(\mathrm{TiO}_{1.984}\right)^{30}$ have been reported, thus creating a very narrow homogeneity range for $\mathrm{TiO}_{2}$ before the lattice tends to break down and the first Magnéli phase appears. ${ }^{82}$

\section{Optical properties of $\mathrm{TiO}_{2}$}

The dielectric functions of anatase and rutile single crystals for the electric field perpendicular and parallel to the $c$-axis (marked with $\perp c$ and $\| c$, respectively) show that in the IR to visible spectral range, anatase is less anisotropic than rutile, whereas in the band-gap region, anatase shows important anisotropy. ${ }^{41,99-105}$ It has been found that depending on the degree of reduction of rutile $\mathrm{TiO}_{2}$, a blue color arises from the visible tail of an IR absorption band peaking at about 0.75-1.18 eV. ${ }^{22,24,31,99-101}$ Similarly, in anatase too, the blue color has been observed, ${ }^{43,102}$ which is caused by a wide absorption band with its maximum in the IR. In addition, a color center at $3 \mathrm{eV}$ due to an oxygen vacancy has been identified giving rise to a yellow color. ${ }^{43}$ Various optical parameters of $\mathrm{TiO}_{2}$ can be found in several literatures. ${ }^{41,103-106}$ Table 1 shows various optical properties of $\mathrm{TiO}_{2}$.

\section{Electrical/electronic properties of $\mathrm{TiO}_{2}$}

The valence band (VB) of wide-gap rutile and anatase consist of $\mathrm{O} 2 p$ states, whereas the conduction band $(\mathrm{CB})$ is formed by Ti $3 d$ states, ${ }^{17,29}$ and detailed calculations on these states can be found in the reports of Tang ${ }^{35}$ and Cangiani. ${ }^{107}$ Table 1 presents various electrical properties of $\mathrm{TiO}_{2}$, and shows that these properties are dependent on the crystallographic direction. As a wide band-gap semiconductor, $\mathrm{TiO}_{2}$ crystals have a high resistivity $\left(\sim 10^{15} \Omega \mathrm{cm}\right),{ }^{30}$ and bulk oxygen vacancies, titanium interstitials, and reduced crystal surfaces are considered to generate shallow electron donor levels that contribute to the electric conductivity of $\mathrm{TiO}_{2} \cdot{ }^{30,108}$ In addition, it has been reported that replacement of oxygen by water vapor remarkably increases the electrical conductivity compared to films deposited with oxygen as reactive gas. ${ }^{109}$ Reduced $\mathrm{TiO}_{2}$ is an $n$-type semiconductor, and the $n$-type conductivity increases with the extent of oxygen loss within the crystal lattice. Point defects in terms of doubly charged oxygen vacancies and interstitial titanium ions with three or four charges affect the conductivity and ionization energy of the rutile crystal. ${ }^{28,82}$ The ionization energies have been reported to be around $0.007-0.08 \mathrm{eV}$ (depending on temperature) for titanium interstitials, ${ }^{26,110}$ whereas oxygen vacancies contribute to the electronic conduction as double donors with a shallow donor level (0-200 meV) and a deep donor level (600-750 meV). 22,30,111 For anatase, the dominant crystal defects are not yet fully understood: some researchers suggested Ti interstitials caused the dominant defects, whereas others suggested oxygen vacancies for the same, but several reports suggested the existence of both phenomena, with an activation energy of carrier generation around $4 \mathrm{meV}^{30,83,112,113}$ In general, oxygen vacancies are observed to be the dominant phenomenon under weakly reducing conditions or low annealing temperatures (below $870 \mathrm{~K}$ in vacuum), whereas in the more reducing conditions and higher annealing temperatures (above $1070 \mathrm{~K}$ in vacuum), titanium interstitials become more predominant in effect. ${ }^{30,81}$ Enthalpy of oxygen vacancy formation is calculated to be around $4.55 \mathrm{eV} /$ vacancy, whereas the same for the triply charged interstitial titanium atom is around 9.11-9.24 eV/interstitial titanium. ${ }^{82,114,115}$ Due to the low value of carrier mobility in rutile $\mathrm{TiO}_{2}$, the transport phenomenon is assumed to follow either small polaron (an electron or hole self-trapped by the local lattice polarization which itself is generating ${ }^{16}$ ) hopping mechanism ${ }^{32,116}$ or phonon scattering. ${ }^{34}$ Especially, the mobility is shown to decrease in higher temperature, suggesting the presence of large polarons (and not localized small polarons, which may become more mobile at higher temperatures due to thermally activated hopping between the atoms ${ }^{13}$ ). However, the mobility may decrease if the small polarons diffuse by tunneling, ${ }^{13}$ and hence, some interesting charge transport models (such as multiband conduction model ${ }^{117}$ ) have been proposed for rutile $\mathrm{TiO}_{2}$. On the other hand, the anatase $\mathrm{TiO}_{2}$ shows higher carrier mobility, suggesting Arrhenius-type thermally activated conduction rather than small polaron hopping in rutile. ${ }^{35,118}$ However, in both the crystal structures, high concentrations of donors lead to the formation of impurity bands, ${ }^{35,118}$ and a transition from nonmetallic to metallic behavior is observed when the donor concentration exceeds a critical value. ${ }^{16,119}$

\section{Fabrication of nanostructured $\mathrm{TiO}_{2}$}

With the rapid development of nanotechnology, $\mathrm{TiO}_{2}$ nanostructures in various forms are finding wider applications than before because of their specifically size-related properties. The energy band structure becomes discrete for nanometer-scale $\mathrm{TiO}_{2}$, and its photophysical, photochemical, and surface properties are quite different from those of the bulk ones due to the quantum size effect, and therefore, many works have focused on the synthesis of nanocrystalline $\mathrm{TiO}_{2}$ with a large specific surface area. Syntheses of 
0-, 1-, and 2-dimensional nanostructures of $\mathrm{TiO}_{2}$ have been reported widely.

\section{$\mathrm{TiO}_{2}$ nanoparticles}

$\mathrm{TiO}_{2}$ nanoparticles have specific advantages in the enhancement of light absorption due to the large fraction of surface atoms. Interband electron transition is the primary mechanism of light absorption in pure semiconductors. These transitions are direct as the momentum gain by the electron from light wave is small in comparison with $\pi h / a$ (' $a$ ' is the lattice constant). This absorption is small in direct-forbidden gap semiconductors, as in the case for $\mathrm{TiO}_{2}$, for which the direct electron transitions between the band centers are prohibited by the crystal symmetry. However, momentum is not conserved if the absorption takes place at the boundary of the crystal, for example, at the surface or at the interface between two crystals, which leads to the indirect electron transitions that can result in the essential enhancement of light absorption. This means that considerable enhancement of the absorption can be observed in small nanocrystals where the surface to volume ratio is very high and the fraction of the surface atoms is sufficiently large. The particle size at which the interface enhancement of the absorption becomes significant is around $20 \mathrm{~nm}$. An additional advantage obtained in nanoparticles in the few nanometer size regimes is that the large surface-to-volume ratio makes possible the timely utilization of photogenerated carriers in interfacial processes. $^{120-122}$

\section{Vacuum-based physical techniques}

Both vacuum-based and solution-based techniques have been adopted for fabrication of $\mathrm{TiO}_{2}$ nanoparticle. One of the early reported nonsolution techniques is metalorganic chemical vapor deposition (MOCVD). Okuyama and colleagues ${ }^{123-125}$ reported the formation of aerosol particles by gas-phase chemical reaction. They have used titanium tetraisopropoxide (TTIP) vapor containing ultrafine $\mathrm{TiO}_{2}$ seed particles in a laminar flow aerosol reactor, and the thermal decomposition of TTIP vapor in the controlled cylindrical furnace produced ultrafine $\mathrm{TiO}_{2}$ nanoparticles of size in the range $10-60 \mathrm{~nm}$. They have also studied the effects of the initial concentration of TTIP vapor, the reaction temperature, the temperature profile of the furnace, and properties of seed particles on the particle size distribution to control the nanoparticle formation. Similarly, Ding and colleagues ${ }^{126}$ synthesized $\mathrm{TiO}_{2}$ nanoparticles supported on porous silica gel (60-100 mesh) via MOCVD process, using TTIP as precursor. The chemical vapor deposition (CVD) reactor was a quartz tube with a porous quartz disk at one end. The reactor temperature was controlled by a tubular furnace. TTIP was introduced into the CVD reactor using nitrogen as the carrier gas. The synthesis of $\mathrm{TiO}_{2}$ nanoparticle/silica gel photocatalyst involved three steps: pretreatment of the support materials, CVD reaction, and calcination. On the other hand, $\mathrm{Li}$ and colleagues ${ }^{127-129}$ reported the fabrication of transition metal and lanthanide ion $\left(\mathrm{Nd}^{-3}, \mathrm{Pd}^{-2}, \mathrm{Pt}^{-4}, \mathrm{Fe}^{-3}\right)$-doped $\mathrm{TiO}_{2}$ nanoparticles via MOCVD process using a TTIP precursor. The CVD system is similar to that given in Ding et al, ${ }^{126}$ except for a horizontal reactor. In addition, unlike other works, ${ }^{126}$ this group used Ar-diluted $\mathrm{O}_{2}$ as the carrier plus reactant gas with an elevated reaction temperature for the formation of $\mathrm{TiO}_{2}$ nanoparticles, thus avoiding the additional calcination step. The average particle size reported was 20-25 nm. For doping of $\mathrm{TiO}_{2}$, neodymium (III) acetylacetonate, palladium (II) acetylacetonate, platinum (IV) acetylacetonate, and iron (III) acetylacetonate precursors were used, and the effect of these dopants on the photocatalytic activity of $\mathrm{TiO}_{2}$ nanoparticle is discussed.

Instead of using costly metalorganic precursors, several groups used inorganic materials in conventional CVD system to fabricate silica-supported 10-20 $\mathrm{nm} \mathrm{TiO}_{2}$ nanoparticles. ${ }^{130-134}$ Leboda and colleagues reported the CVD syntheses of titania/silica gel ${ }^{130}$ and titania/fumed silica. ${ }^{131}$ In addition, CVD preparations of titania/silica gel and titania/ ZSM-5 were also reported by Schrijnemakers and collleagues ${ }^{132}$ and Stakheev and colleagues, ${ }^{133}$ respectively. Xia and colleagues ${ }^{134}$ reported the gas-phase/CVD synthesis of $\mathrm{TiO}_{2}$ nanopowder and investigated the influence of various deposition parameters on particle size. In all these reports, titanium tetrachloride $\left(\mathrm{TiCl}_{4}\right)$ was applied as the precursor for CVD reaction and a two-step synthesis procedure was used. $\mathrm{TiCl}_{4}$ was first introduced and adsorbed onto the supports, and then oxygen/water vapor was brought through to start the oxidation/hydrolysis of $\mathrm{TiCl}_{4}$ species. Especially, oxidation of $\mathrm{TiCl}_{4}$ vapor, also known as the 'chloride' process in titania industry, ${ }^{135-137}$ now becomes one of the main gas-phase routes for commercial production of titania nanopowder. $\mathrm{TiCl}_{4}$ is an inorganic low-cost precursor, which can be readily oxidized or hydrolyzed to prepare $\mathrm{TiO}_{2}$ powders according to the following equations:

$$
\begin{gathered}
\mathrm{TiCl}_{4}(\mathrm{~g})+\mathrm{O}_{2}(\mathrm{~g}) \rightarrow \mathrm{TiO}_{2}(\mathrm{~s})+2 \mathrm{Cl}_{2}(\mathrm{~g}) \\
\mathrm{TiCl}_{4}(\mathrm{~g})+2 \mathrm{H}_{2} \mathrm{O}(\mathrm{g}) \rightarrow \mathrm{TiO}_{2}(\mathrm{~s})+4 \mathrm{HCl}(\mathrm{g})
\end{gathered}
$$

The oxidation method is an important route in a typical gas-phase/CVD method. In gas-phase processes, greater 
equilibrium constant $\left(K_{\mathrm{p}}\right)$ favors the formation of smaller particles, and the $K_{\mathrm{p}}$ value that exceeds $10^{2.3}$ is necessary for preparation of nanoscale particles. ${ }^{134}$ Vemury and colleagues ${ }^{138}$ reported the synthesis of $\mathrm{TiO}_{2}$ nanoparticles via oxidation of $\mathrm{TiCl}_{4}$ vapors in electrically assisted hydrocarbon flames using needle-shaped or plate electrodes. A laminar premixed burner-stabilized flame reactor is used to make titania nanoparticles in the presence of externally controlled electric field. $\mathrm{TiCl}_{4}$ vapor premixed with nitrogen, oxygen, and methane were sent through the burner with argon as carrier gas. Oxide particles are formed in the flame by oxidation/ hydrolysis of the precursors. External electrodes are used to create the electric field across the flame. ${ }^{139}$ Vemury and colleagues observed that the particle size decreases with increasing field strength across the flame. In addition, it charged the newly formed particles, resulting in electrostatic repulsion and dispersion, which decreased particle growth by coagulation, thus retaining the nanostructure of synthesized particles. A laser-induced CVD process to prepare $\mathrm{TiO}_{2}$ nanopowders of crystallite size around $20-30 \mathrm{~nm}$ has also been attempted by Casey and Haggerty. ${ }^{140}$ Titanium alkoxide vapor was heated with $10.591 \mu \mathrm{m}$ IR radiation from a $\mathrm{CO}_{2}$ laser. Among other physical techniques, Epperson and colleagues ${ }^{141}$ used an inert gas condensation technique, where the metallic $\mathrm{Ti}$ is evaporated in He pressure and then slowly exposed to $\mathrm{O}_{2}$ atmosphere to obtain $\mathrm{TiO}_{2}$ nanoparticles.

\section{Solution-based chemical techniques}

Among wet-chemical processes, one of the classical methods was a sulfate process, ${ }^{142}$ where spherical titania nanoparticles were prepared from an aqueous solution of $\mathrm{TiOSO}_{4}$ by homogeneous precipitation using urea at $70^{\circ} \mathrm{C}-90^{\circ} \mathrm{C}$. Especially, the presence of urea dictates the spherical shape of the nanoparticles. As-synthesized powders were amorphous hydrates of titania containing a sulfate group and crystallize by calcination into anatase $\left(>500^{\circ} \mathrm{C}\right)$ and rutile $\left(>900^{\circ} \mathrm{C}\right)$. In calcination, the particles shrink, but hold their original spherical shapes. Other wet-chemical processes include the sol-gel method, which is one of the widely used methods for $\mathrm{TiO}_{2}$ nanoparticle formation, ${ }^{143-161}$ because of its advantage of controlling the particle size and morphology through experimental conditions. ${ }^{154}$ Most of the reports on sol-gel syntheses of $\mathrm{TiO}_{2}$ nanoparticles involved titanium alkoxide (titanium isopropoxide [TIPO], titanium butoxide, titanium ethylhexoxide, tetra- $n$-butyl titanate) as the Ti source. ${ }^{143-146-}$ ,148-158,160,161 Few used $\mathrm{TiCl}_{4}$ as the Ti precursor solution. ${ }^{147,159}$ The process generally starts with the hydrolysis of the source solution to form the complex sol, followed by heat treatment and aging to obtain the gel, and finally, annealing at elevated temperature to obtain the required oxide. A typical sol-gel synthesis process of $\mathrm{TiO}_{2}$ nanoparticles using TIPO as Ti source is as follows: first, TIPO is mixed with tetraethanolamine (TEOA) with TEOA:TIPO $=2: 1$ ratio, which produces a sol of organometallic complex, and then refluxed and aged under $\mathrm{H}_{2} \mathrm{O}\left(+\mathrm{HClO}_{4} / \mathrm{NaOH}\right)$ solution for $24 \mathrm{~h}$ (at $100^{\circ} \mathrm{C}$ ) to obtain Ti-contained gel, which is subsequently aged for $72 \mathrm{~h}\left(\right.$ at $140^{\circ} \mathrm{C}$ ) to obtain the $\mathrm{TiO}_{2}$ nanoparticle. ${ }^{154}$ Phase-pure anatase nanoparticles are generally prepared from titanium (IV) isopropoxide, TEOA, and/or mild acid-like acetic acid. ${ }^{154,162}$ When stronger acids are used, a fraction of the product usually consists of brookite nanoparticles. ${ }^{163,164}$ The synthesis of brookite nanoparticles has been reported by thermolysis of $\mathrm{TiCl}_{4}$ in aqueous $\mathrm{HCl}$ solution. ${ }^{165}$ The composition of the reaction product was found to be strongly dependent on the Ti:Cl concentration ratio ( 17-35). Phasepure rutile nanoparticles have been prepared from $\mathrm{TiCl}_{4}$ or $\mathrm{TiCl}_{3}$ in $\mathrm{HCl}$ solution or from titanium (IV) isopropoxide in nitric acid at $\mathrm{pH}=0.5 .^{166-170}$ Several authors have compared synthesis methods for the three phases, in order to determine the effect of crystal structure on the physical properties. ${ }^{171-174}$ Reyes-Coronado and colleagues ${ }^{174}$ reported the syntheses of phase-pure anatase, rutile, and brookite $\mathrm{TiO}_{2}$ nanoparticles via a combinatorial approach using both sol-gel and hydrothermal treatment. Amorphous $\mathrm{TiO}_{2}$ nanoparticles were first prepared by sol-gel technique using Ti alkoxide as the source solution followed by hydrothermal treatment at three different acid concentrations and temperatures in order to establish the conditions for obtaining phase-pure products of anatase, rutile, and brookite phases separately. Typically, the hydrothermal condition for the synthesis of anatase phase is reported to consist of heat treatment at $200^{\circ} \mathrm{C}$ for $6 \mathrm{~h}$ under $1.5 \mathrm{M}$ acetic acid solution. For obtaining rutile phase, these parameters are $200^{\circ} \mathrm{C}$ for $8 \mathrm{~h}$ under $4 \mathrm{M} \mathrm{HCl}$ environment, whereas the same for obtaining brookite phase is $175^{\circ} \mathrm{C}$ for $7 \mathrm{~h}$ under $3 \mathrm{M} \mathrm{HCl}$ solution. Details can be found in the Reyes-Coronado et al. ${ }^{174}$

Another chemical process used to synthesize $\mathrm{TiO}_{2}$ nanoparticle is hydrothermal synthesis, ${ }^{175-177}$ where $\mathrm{TiCl}_{4}$ was used as the starting materials for Ti source. Rao and Dutta $^{178}$ used Ti alkoxide precursor in toluene solvent to hydrothermally synthesize $\mathrm{TiO}_{2}$ nanoparticle. Palmisano and colleagues ${ }^{179}$ used a coprecipitation method using $\mathrm{TiCl}_{3}$ and aqueous ammonia to form titanium hydroxides followed by firing in air at elevated temperature to obtain $\mathrm{TiO}_{2}$ submicron particles of size $100-300 \mathrm{~nm}$. Akhtar et al ${ }^{180}$ and Shi et al ${ }^{181}$ used direct vapor-phase oxidation of $\mathrm{TiCl}_{4}$ in an aerosol 
reactor at elevated temperatures to obtain $\mathrm{TiO}_{2}$ nanoparticles. Jagadale et $\mathrm{al}^{160}$ and Gao et al ${ }^{182}$ used a wet-chemical peroxide-based synthesis route, where $\mathrm{H}_{2} \mathrm{TiO}_{3}$ (or TTIP) dissolved in $\mathrm{H}_{2} \mathrm{O}_{2}$ and/or ammonia solution were used to form peroxotitanate, which was subsequently transformed to $\mathrm{TiO}_{2}$ nanoparticle via low-temperature aging or calcination. Mahshid and colleagues ${ }^{183}$ used peptization method to form $\mathrm{TiO}_{2}$ nanoparticles. Initially, $\mathrm{TiO}_{2}$ colloids in the nanometer range were prepared by hydrolysis and condensation of titanium alkoxide in aqueous media. In the presence of water, alkoxide hydrolyzes and subsequently polymerizes to form a 3-dimensional oxide network. These reactions can be schematically represented as follows:

$$
\begin{aligned}
\mathrm{Ti}(\mathrm{OR})_{4}+ & 4 \mathrm{H}_{2} \mathrm{O} \rightarrow 2 \mathrm{Ti}(\mathrm{OH})_{4} \\
+ & 4 \mathrm{ROH} \text { (hydrolysis) }, \\
\mathrm{Ti}(\mathrm{OH})_{4} \rightarrow & \mathrm{TiO}_{2}, x \mathrm{H}_{2} \mathrm{O}+(2-x) \mathrm{H}_{2} \mathrm{O} \\
& (\text { condensation }),
\end{aligned}
$$

where R is ethyl, $i$-propyl, $n$-butyl, etc. ${ }^{184}$ The size, stability, and morphology of the sol produced from alkoxide route is strongly affected by the water-to-Ti molar ratio $\left(r=\left[\mathrm{H}_{2} \mathrm{O}\right] /[\mathrm{Ti}]\right)$. At $r \leq 10$, spherical, relatively monodisperse particles with diameters of $0.5-1 \mathrm{~mm}$ are obtained. On the other hand, at higher $r$ values, the particles formed are unstable and precipitate in the form of large aggregates, which can subsequently be chemically peptized to final sizes that are usually $<100 \mathrm{~nm}$ in diameter. Because of the small size of particles that are formed under these conditions, formation of colloidal $\mathrm{TiO}_{2}$ at high $r$ values is of great interest. In addition, acidity of the solution has a strong influence on the size distribution of nanoparticles. ${ }^{183} \mathrm{Li}$ and colleagues ${ }^{185}$ used a solvothermal method to synthesize nanoparticles by controlling the hydrolyzation reaction of titanium butoxide using $\mathrm{NH}_{4} \mathrm{HCO}_{3}$ and linoleic acid. They have also described the reaction mechanism and formation process of the $\mathrm{TiO}_{2}$ nanoparticles and nanorods by controlling the solvothermal reaction parameters, such as reaction temperatures, concentrations, reaction durations, and so on. Seo et al ${ }^{186}$ demonstrated the synthesis of $\mathrm{TiO}_{2}$ nanoparticles by a high-temperature nonhydrolytic method using $\mathrm{TiCl}_{4}$, oleic acid, and oleyl amine mixture in a reaction flask at $270^{\circ} \mathrm{C}$. After $10 \mathrm{~min}$, the reaction mixture was quenched, and $\mathrm{TiO}_{2}$ nanoparticles were separated by a size-selective precipitation process. Teleki and colleagues ${ }^{187}$ used a flame-based spray pyrolysis method to synthesize $\mathrm{TiO}_{2}$ nanoparticles. TTIP, diluted in a mixture of xylene and acetonitrile, was fed into a combustible spray to obtain the powdered nanoparticles. It is to be noted that for the physical- or gas-phase processes of $\mathrm{TiO}_{2}$ nanoparticle syntheses, unlike the liquid-phase methods, process parameters can be adjusted easily to produce nanoparticles with varied crystallinity and surface area without the necessity of posttreatments.

\section{One-dimensional $\mathrm{TiO}_{2}$ nanostructures}

One-dimensional nanostructures in the form of nanowires, nanorods, nanotubes, nanopillars, nanocylinders, nanoneedles, and nanowhiskers have received considerable attention because of their potential applications in catalysts as carrier materials, in pharmacy as drug-delivery agents, in nanoelectronics for the isolation of ultrasmall wires, or in basic research to study host-guest chemistry in mesoscopic materials. ${ }^{188-190} \mathrm{TiO}_{2}$-based nanotubes have also attracted wide attention owing to their potential applications in highly efficient photocatalysis, ${ }^{191}$ lithium ion batteries, ${ }^{192}$ photovoltaic cells, ${ }^{193-195}$ and environmental applications. ${ }^{196}$

\section{Solution-based chemical techniques}

Hoyer was the first to attempt to prepare $\mathrm{TiO}_{2}$ nanotubes. ${ }^{197}$ Starting from a porous alumina membrane (PAM), a polymer mold suitable for the formation of $\mathrm{TiO}_{2}$ nanotubes was obtained. The tubular structure was formed by electrochemical deposition in the mold. After dissolution of the polymer, $\mathrm{TiO}_{2}$ nanotubes were obtained, which were amorphous, and transformed into polycrystalline anatase structure after heat treatment. The typical fabrication steps consist of anodic alumina membrane fabrication and gold evaporation on top of the membrane (step 1), followed by casting of poly(methyl methacrylate) (PMMA) within the pores of alumina membrane (step 2). After that the alumina membrane is removed to obtain negative mold (upside down) with evaporated gold inside the replicated pores of PMMA (step 3). Thereafter, electroless gold deposition on the sidewalls of the PMMA mold is performed (step 4) followed by the electrodeposition of $\mathrm{TiO}_{2}$ on the walls of the mold. Finally, the PMMA mold is removed to obtain free-standing $\mathrm{TiO}_{2}$ nanorods covered with gold layers (step 5).

Kasuga and colleagues ${ }^{198,199}$ synthesized $\mathrm{TiO}_{2}$ nanoneedles (anatase phase) using sol-gel-derived fine $\mathrm{TiO}_{2}$-based powders under hydrothermal $\mathrm{NaOH}$ treatement at $110^{\circ} \mathrm{C}$ for $20 \mathrm{~h}$. Following their pioneering works, several research groups ${ }^{200-219}$ have also synthesized 1-dimensional $\mathrm{TiO}_{2}$ nanostructures by similar chemical processes with some variations in experimental conditions and/or reagents. For example, Feng and colleagues ${ }^{210}$ used tetrabutyl titanate, 
titanium tetrachloride in $\mathrm{HCl}$ with toluene as the nonpolar solvent to form $\mathrm{TiO}_{2}$ nanowires. Liu and Aydil ${ }^{215}$ used titanium butoxide, TIPO, and titanium tetrachloride as Ti precursors in $\mathrm{HCl}$ solution to form nanowires. They also studied the effects of surfactants or salts such as ethylenediamine, ethylenediaminetetraacetic acid, sodium dodecyl sulfate, cetyltrimethylammoniumbromide, polyvinylpyrrolidone, and sodium chloride on the nanowire properties. This group has also used a three-step (hydrothermal + ion exchange + annealing) synthesis of $\mathrm{TiO}_{2}$ nanowires on titanium foil. ${ }^{215}$ In the first step, sodium titanate nanotubes were hydrothermally formed on $\mathrm{Ti}$ foil using a $\mathrm{NaOH}$ and $\mathrm{H}_{2} \mathrm{O}_{2}$ solution. In the second ion-exchange step, the titanium foil with nanotubes was immersed in $\mathrm{HCl}$ to exchange the $\mathrm{Na}^{+}$with $\mathrm{H}^{+}$and thus transform the sodium titanate nanotubes to hydrogen titanate nanotubes. In the third step, the hydrogen titanate nanotube-coated titanium foil was annealed at $500^{\circ} \mathrm{C}$ to convert the nanotubes to anatase $\mathrm{TiO}_{2}$ nanowires. Chang and colleagues ${ }^{216}$ used a similar hydrothermal method to the Kasuga group ${ }^{198,199}$ with a microwave oven as the external power source for the reaction. Zhu and colleagues ${ }^{200}$ used sonication-assisted hydrothermal growth of $\mathrm{TiO}_{2}$ nanotubes and nanowhiskers. Wang and colleagues ${ }^{217}$ also used a similar hydrothermal growth of $\mathrm{TiO}_{2}$ nanowires on a spiralshaped Ti wire. Tian and colleagues ${ }^{219}$ seeded the substrate with $\mathrm{TiO}_{2}$ nanoparticles followed by a similar hydrothermal method. ${ }^{198,199}$ With respect to the formation mechanism of $\mathrm{TiO}_{2}$ nanotubes, Kasuga et al ${ }^{199}$ tentatively proposed that $\mathrm{TiO}_{2}$ nanotubes were grown by the connection between the two ends of $\mathrm{Ti}-\mathrm{OH}$ forming sheets during the process of washing the alkali-treated $\mathrm{TiO}_{2}$ raw materials. Later Yao and colleagues $^{205}$ explained the nanotube formation mechanism using transmission electron microscopy (TEM) studies. They observed that the $\mathrm{TiO}_{2}$ nanotube walls were not seamless, unlike multiwall carbon nanotubes (CNTs). They argued that crystalline $\mathrm{TiO}_{2}$ raw material underwent delamination in the alkali solution to produce single-layer $\mathrm{TiO}_{2}$ sheets during alkali treatment. These single-layer $\mathrm{TiO}_{2}$ sheets were later rolled to form $\mathrm{TiO}_{2}$ nanotubes.

Encouraged by these methods, various groups reported the syntheses of 1-dimensional $\mathrm{TiO}_{2}$ nanostructures via porous membrane-based sol-gel and electrochemical routes. ${ }^{196,220-261}$ Use of PAM as the host to grow oriented $\mathrm{TiO}_{2}$ nanowires through the PAM nanopores via sol-gel method has been attempted by several groups. ${ }^{220-237} \mathrm{Ti}$ alkoxides have been used as the source solution for the sol-gel syntheses to fill the PAM pores followed by oxygen/air annealing to obtain the $\mathrm{TiO}_{2}$ nanowires. However, this sol-gel template method has some shortcomings. As the only driving force of this technique is capillary action, for the sol with higher concentration, filling of pores is difficult, whereas for lowconcentration sol, the as-synthesized nanomaterials lead to shrinkage and cracking. ${ }^{262}$ To overcome these difficulties, Miao and colleagues ${ }^{226}$ reported an electrochemically induced sol-gel method to prepare $\mathrm{TiO}_{2}$ single-crystalline nanowire arrays. For that, one end of the pores are coated with metallic cathode, and an external magnetic field is applied to force the Ti-containing ions to enter into the pores. First, the hydroxyl ion was generated due to the cathodic reduction, and then the generation of $\mathrm{OH}^{-}$ions increases the local $\mathrm{pH}$ at the electrode surface, resulting in the titanium oxyhydroxide gel formation in the pores of the template. Finally, subsequent heat treatment and the removal of the PAM results in the formation of $\mathrm{TiO}_{2}$ single-crystalline nanowire arrays. ${ }^{226}$ Similar methods have been adopted by various others groups. ${ }^{227-230}$ For example, Lin et $\mathrm{al}^{227}$ and Zhang et $\mathrm{al}^{228}$ used a similar electrochemically induced method to form single-crystalline anatase $\mathrm{TiO}_{2}$ nanowires with diameters about $15 \mathrm{~nm}$ and lengths about $6 \mu \mathrm{m}$ within hexagonally packed nanochannels of porous alumina. They have used acidic $\mathrm{TiCl}_{3}$ as the precursor solution, and using the potentiostatic method with a three-electrode arrangement with a saturated calomel reference electrode (SCE) and a Pt counter electrode, anodic oxidative hydrolysis was done followed by oxygen annealing at $500^{\circ} \mathrm{C}$ to obtain the desired oxide nanowire arrays. Liu and Huang ${ }^{229}$ used pulsed electrodeposition with acidic $\mathrm{TiCl}_{3}$ as electrolyte solution to grow $\mathrm{TiO}_{2}$ nanowire with PAM.

Caruso et $\mathrm{al}^{231}$ used electrospun polymer fibers as host to coat with amorphous $\mathrm{TiO}_{2}$ using a sol-gel technique. On removal of the thermally degradable polymer, hollow titania fibers are produced. The sol-gel coating was able to mimic the finer details of the fiber, thereby forming nodules on the inner walls of the tubes. Similar methods have been adopted by Formo et $\mathrm{al}^{232}$ and Archana et $\mathrm{al}^{233}$ Jung et $\mathrm{al}^{234}$ and Kobayashi et $\mathrm{al}^{235}$ demonstrated a new methodology to prepare the $\mathrm{TiO}_{2}$ hollow fibers, double-layered tubular structures, and helical ribbons using a crown-appended cholesterol-based organic gelator in the sol-gel polymerization process of $\mathrm{Ti}\left[\mathrm{OCH}\left(\mathrm{CH}_{3}\right)_{2}\right]_{4}$ followed by oxygen annealing at elevated temperature to remove organic components and obtain $\mathrm{TiO}_{2}$ nanostructures. Similarly, Zhang and $\mathrm{Qi}^{236}$ used bacterial cellulose membranes as host and followed similar methods stated above to obtain $\mathrm{TiO}_{2}$ nanostructures. Chen and colleagues ${ }^{237}$ synthesized a $\mathrm{TiO}_{2}$ nanowire network on electrospun polymer template using $\mathrm{a}_{2} \mathrm{O}_{2}, \mathrm{TiOSO}_{4}$, and $\mathrm{KNO}_{3}$ sol-gel bath. 
Anodization of Ti foils and films is one of the most widely used methods for template-free electrochemical deposition of $\mathrm{TiO}_{2}$ nanowire/nanotube. After the first report of anodic oxidation of Ti film by Zwilling and colleagues, ${ }^{238,239}$ several groups started working on the fabrication of $\mathrm{TiO}_{2}$ nanowires using the anodization method. ${ }^{196,240-261} \mathrm{HF} / \mathrm{NH}_{4} \mathrm{~F} / \mathrm{KF} / \mathrm{NaF} /$ $\left(\mathrm{NH}_{4}\right)_{2} \mathrm{SO}_{4} / \mathrm{NaHSO}_{4}$ diluted in organic solvent or water were taken as the electrolyte in standard two-electrode or threeelectrode electrodeposition system with Pt as counter electrode and sample (Ti foil or Ti-coated substrate) as anode (along with a reference electrode for three-electrode system). Highly ordered, oriented hollow nanotubes with very high aspect ratio can be obtained by this method. It should be noted that for aqueous $\mathrm{HF} / \mathrm{NH}_{4} \mathrm{~F}$ used as electrolyte, the length of the nanorods is rather small, which is due to the dissolution of formed $\mathrm{TiO}_{2}$ under hydrogen ions according to the following reaction process:

$$
\mathrm{TiO}_{2}+6 \mathrm{~F}^{-}+4 \mathrm{H}^{+} \rightarrow \mathrm{TiF}_{6}^{-2}+2 \mathrm{H}_{2} \mathrm{O}
$$

This has been overcome by using nonaqueous organic polar electrolytes ${ }^{252}$ to decrease the formation of hydrogen ions that are derived from the electrolyte solution, thus reducing the chemical dissolution of formed $\mathrm{TiO}_{2}$. Using this method, $\mathrm{TiO}_{2}$ nanotube arrays of $\sim 1000 \mu \mathrm{m}$ in length and approximate 10,000 aspect ratio have been achieved..$^{252}$

It is also noteworthy that for most of the anodization processes, commercially available $\mathrm{Ti}$ foil was used as the source material. Similarly, for PAM-directed growth of the $\mathrm{TiO}_{2}$ nanowires, the host PAM is fabricated from either $\mathrm{Al}$ foil or anodiscs purchased from commercially available sources. Since the as-synthesized nanowires/nanotubes are not supported by any rigid substrate ( $\mathrm{Si}$, glass, quartz, and so on), they are fragile and unsuitable for practical device applications. For solid-state device compatibility as well as for some specific device applications in solar cells, field emission studies and sensor applications using vertically standing nanorods supported by rigid substrate are very important. ${ }^{263-265}$ Very few groups reported the syntheses of $\mathrm{TiO}_{2}$ nanowires/rods on rigid substrates. ${ }^{210,237,247,253}$ These groups have used indium tin oxide (ITO)/fluorine-doped tin oxide-coated glass/Si substrate with sputter-deposited/ evaporated Ti thin films on them as the source materials.

For other chemical-based $\mathrm{TiO}_{2}$ nanowire syntheses, Venkataramanan and colleagues ${ }^{266}$ used an environmentally benign approach for the synthesis of titania nanowire using natural fibers (cellulose) as templates and ionic liquid (1-butyl-3-methylimidazolium chloride) as solvent to obtain $\mathrm{TiO}_{2}$-nanowire/cellulose composite. $\mathrm{Li}$ and $\mathrm{Wang}^{267}$ synthesized rutile $\mathrm{TiO}_{2}$ nanowhiskers by direct annealing of a precursor powder containing homogeneously mixed $\mathrm{NaCl}$ and $\mathrm{Ti}(\mathrm{OH})_{4}$ particles. Daothong and colleagues ${ }^{268}$ fabricated single-crystalline $\mathrm{TiO}_{2}$ nanowires by oxidation of titanium substrates (wire mesh, $\phi=0.25 \mathrm{~mm}$ ) in the presence of ethanol vapor at a low pressure (10 Torr) and high temperature $\left(450^{\circ} \mathrm{C}\right)$. Kim and colleagues ${ }^{269}$ used a peptide organogel template to fabricate $\mathrm{TiO}_{2}$ nanonetwork via atomic layer deposition (ALD) process with TTIP and $\mathrm{NH}_{3} / \mathrm{O}_{2}$ mixed gas as Ti precursor and reactant gas, respectively. Sander and colleagues ${ }^{270}$ also used ALD to fabricate $\mathrm{TiO}_{2}$ nanowires within PAM followed by wet etching of the membrane to obtain oriented nanowires. Park and colleagues ${ }^{271}$ used a simple $\mathrm{Cu}$ catalyst-assisted thermal annealing process of Ti foil to obtain $\mathrm{TiO}_{2}$ nanowire and other nanostructures. Wu and $\mathrm{Xue}^{272}$ also used a thermal annealing technique of Ti foil treated with an organic solution containing $\mathrm{H}_{2} \mathrm{O}_{2}$.

\section{Vacuum-based physical techniques}

Among physical techniques for the syntheses of $\mathrm{TiO}_{2}$ nanowires, various methods have been adopted which include thermal/e-beam evaporation, deposition of Ti and/or $\mathrm{TiO}_{2}$ in a vacuum evaporator, or RF heating in a controlled atmosphere. ${ }^{273-280}$ Xiang et $\mathrm{al}^{273}$ thermally evaporated $\mathrm{Ti}$ powder in a controlled furnace to deposit $\mathrm{TiO}_{2}$ nanowire on a Si substrate. By controlling the growth conditions such as the reaction time and the position of the substrate, this group has reported the synthesis of $\mathrm{SiO}_{2} / \mathrm{TiO}_{2}$ shell-core nanostructure. ${ }^{274}$ Another group ${ }^{275-278}$ used a two-step thermal evaporation technique, where Ti powder was heated by a radio frequency coil inside a quartz reactor under Ar-diluted $\mathrm{O}_{2}$ atmosphere to grow $\mathrm{TiO}_{2}$ nanowires on a $\mathrm{Si}$ substrate. On the other hand, Wolcott and colleagues ${ }^{279}$ used electronbeam evaporation of $\mathrm{TiO}_{2}$ powder to synthesize nanowires on glass substrates. Other vacuum-based techniques include $\mathrm{CVD}$ of $\mathrm{TiO}_{2}$ nanowhiskers from a system of $\mathrm{TiF}_{4}-\mathrm{H}_{2} \mathrm{O}$ at elevated temperatures. ${ }^{280}$ Francioso and colleagues ${ }^{281}$ used photolithography techniques to fabricate $\mathrm{TiO}_{2}$ nanowires from thermally annealed $\mathrm{TiO}_{2}$ thin-film deposited on $\mathrm{Si}$ substrate. The fabrication steps consist of $\mathrm{TiO}_{2}$ thin-film deposition on Si substrate (in fact on a native oxide layer on the Si substrate) followed by spin coating of photoresist and the pattern transfer via masking and UV exposure. After the development, the $\mathrm{TiO}_{2}$ surface becomes structured with covered photoresist consisting of patterned holes that partially expose the $\mathrm{TiO}_{2}$ surface underneath via the holes on the photoresist. Finally, a plasma-etching treatment was performed to 
etch the exposed parts of the $\mathrm{TiO}_{2}$ layer vertically downward to obtain 1-dimensional nanostructures of $\mathrm{TiO}_{2}$. After the removal of the photoresist, an array of vertically standing $\mathrm{TiO}_{2}$ nanowires on the $\mathrm{Si}$ substrate is obtained. Details of the fabrication procedure can be found in Francioso et al. ${ }^{281}$

Lee and colleagues ${ }^{282}$ used vapor-liquid-solid (VLS) growth of $\mathrm{TiO}_{2}$ nanowires on catalyzed (Au) sapphire and quartz substrates using a thermally evaporated Ti powder as source under Ar-diluted $\mathrm{O}_{2}$ as carrier and reactive gases. It is to be noted that the VLS growth technique is a relatively new process, which is mainly used to grow nanowires/rods/ whiskers of various elemental and compound materials. ${ }^{283}$ Generally, nanowires of semiconducting materials are conveniently grown via the VLS process, where material from the vapor is incorporated via a liquid catalyst, commonly a low-melting eutectic alloy. Semiconductor nanowires with diameters ranging from a few to several hundred nanometers can be grown on a solid substrate by this method. By modifying the growth conditions, lateral and longitudinal control over the nanowire size, composition, and doping can be achieved. The central idea of the VLS growth technique is the participation of the catalyst during growth process, which is one of the important key factors for the synthesis of nanowires. Another important factor is to keep the catalytic particles in a liquid state during the VLS growth at high temperatures. In general, the VLS growth process can be divided into two stages: the nucleation and the growth of the liquid droplets, and growth of the nanowires from the droplets due to supersaturation by the VLS mechanism. The temperature should be kept high, but the exact temperature will depend on the catalyst used and can be chosen from the phase diagram of the catalytic material, considering the fact that the melting point of nanosized catalytic particles is less than that of bulk material. For example, in VLS growth of $\mathrm{TiO}_{2}$ nanowires, Au catalyst is used at $1050^{\circ} \mathrm{C} .{ }^{282} \mathrm{~A}$ VLS apparatus, in general, consists of a tube vacuum furnace with Ar flow through it, an effusion cell to provide the vaporized material (to be grown as nanowires), and the substrate with metallic catalyst on which the required nanowire will be grown. A schematic representation of the system is shown in Figure 5. The diameter of the wires is set by the catalyst dimension (typically $1-100 \mathrm{~nm}$ ), and the nanowire length (typically $1-100 \mu \mathrm{m}$ ) is proportional to the growth time. During growth, the material to be deposited (here Ti powder) is provided by thermal evaporation of a powder target. The resulting vapor is transported to the substrate in an argon (and oxygen for reactive deposition) flow. The vapor dissolves in the metal particles (Au catalyst) and forms a eutectic mixture. When the liquid particle becomes oversaturated, the crystalline nanowire $\left(\mathrm{TiO}_{2}\right)$ starts to grow. Because new vapor is supplied continuously, the nanowire will keep on growing and can reach lengths exceeding $100 \mu \mathrm{m}$. The growth mechanism is schematically described in Figure 6.

\section{Other $\mathrm{TiO}_{2}$ nanostructures and nanocomposites}

Formation of various other nanostructures of $\mathrm{TiO}_{2}$ includes nanoplatelet via hydrothermal/anodization route, ${ }^{255,284}$ porous

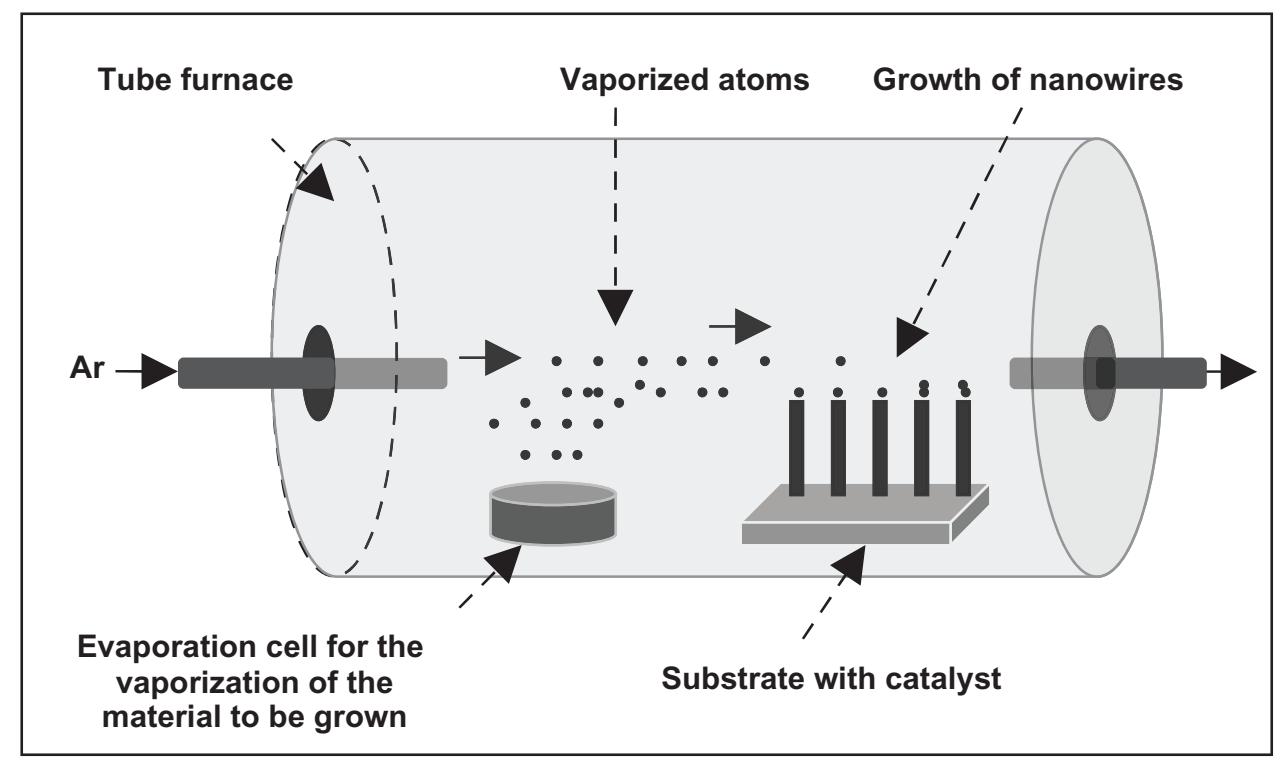

Figure $\mathbf{5}$ Schematic design of a VLS system. 


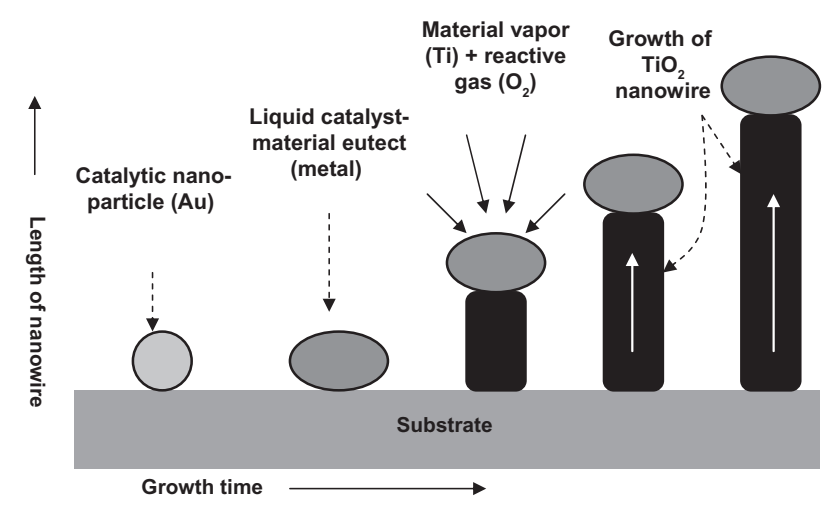

Figure 6 Mechanism of vapor-liquid-solid growth of $\mathrm{TiO}_{2}$ nanowires.

nanofoam via direct decomposition and reaction of hydrogen peroxide inside $\mathrm{a} \mathrm{TiO}_{2} /$ hexadecylamine slurry dispersion, ${ }^{285}$ and nanocrystalline thin film via spray deposition of $\mathrm{TiO}_{2}$ nanoparticles ${ }^{178}$. As far as nanocomposites of $\mathrm{TiO}_{2}$ with other organic/inorganic materials are concerned, $\mathrm{TiO}_{2}$ at narrowgap semiconductor materials garnered much interest in dyesensitized $\mathrm{TiO}_{2}$-based solar cells. ${ }^{144,286-296}$ Narrow band-gap semiconductors such as $\mathrm{CdS}, \mathrm{CdSe}, \mathrm{CdTe}, \mathrm{PbS}, \mathrm{Bi}_{2} \mathrm{~S}_{3}$, and $\mathrm{CuInS}_{2}$, are used with $\mathrm{TiO}_{2}$ nanomaterials, because these narrow-gap materials absorb light in the visible region and transfer electrons to large band-gap $\mathrm{TiO}_{2}$, and thus serve as sensitizers. The fabrication of core-shell or similar composite structures generally follows chemical/hydrothermal syntheses of $\mathrm{TiO}_{2}$ core followed by the narrow-gap nanoparticles deposition via chemical bath deposition/spray pyrolysis/ CVD/ALD/solvothermal methods. Cheng and colleagues ${ }^{297}$ reported the fabrication of highly ordered $\mathrm{WO}_{3} / \mathrm{TiO}_{2}$ composite nanotubes via a combinatorial PAM-based sol-gel method. Brinley et al ${ }^{298}$ reported $\mathrm{SiO}_{2}-\mathrm{TiO}_{2}$ hybrid antireflective coating via a sol-gel process. For enhancement of photocatalytic activity of $\mathrm{TiO}_{2}$, various groups reported the syntheses of $\mathrm{TiO}_{2}$-activated carbon or $\mathrm{TiO}_{2}-\mathrm{CNT}$ mixture or nanocomposite, which limit electron-hole recombination ${ }^{299-306}$ and thus improve reactivity. The syntheses of $\mathrm{TiO}_{2} / \mathrm{CNT}$ nanocomposites include sol-gel, CVD, and PVD techniques. ${ }^{305,307-309}$ In addition, $\mathrm{TiO}_{2}$-polymer nanocomposite gained renewed interest to create novel organic/inorganic hybrid materials for improved photocatalytic activity, water/air purification, or bactericidal antifouling. Several different methods have been adopted to integrate $\mathrm{TiO}_{2}$ with target materials, which include self-assembly monolayer adsorption on functionalized surfaces, sol-gel synthesis, vacuum vaporization, sputtering, CVD/MOCVD, Langmuir-Blodgett method, ultrasonic irradiation, enzymatic synthesis, or surface-initiated polymerization. ${ }^{310-319}$

\section{Applications of nanostructured $\mathrm{TiO}_{2}$ Fundamentals of $\mathrm{TiO}_{2}$ photoinduced phenomena}

After the pioneering report of Fujishima and Honda on the photocatalytic splitting of water on $\mathrm{TiO}_{2}$ electrodes,${ }^{64}$ a new era in the heterogeneous photocatalysis has begun and tremendous research efforts in understanding the fundamental processes and in enhancing the photocatalytic efficiency of $\mathrm{TiO}_{2}$ have been performed by chemists, physicists, materials scientists, chemical engineers, and others. The large oxidizing power of photogenerated holes in titania coupled with the low cost and relative physical and chemical stability of $\mathrm{TiO}_{2}$ render it the semiconductor material of choice for many applications that exploit solar energy including DSSCs where sunlight is converted into electricity, water photoelectrolysis where solar energy is converted into a chemical fuel (hydrogen), photocatalytic conversion of $\mathrm{CO}_{2}$ to hydrocarbon fuels, and as a photocatalyst where organic pollutants are degraded into more environmentally friendly chemical species. ${ }^{320-326}$ All of these applications require $\mathrm{TiO}_{2}$ to be in contact with a solid, liquid, or gaseous electrolyte; consequently, $\mathrm{TiO}_{2}$ becomes a prime candidate for the development of nanoscale architectures. Titania is a wide band-gap semiconductor having an $E_{\mathrm{g}}$-value ranging from 3.0 to $3.2 \mathrm{eV}$, which depends on the crystalline phase, ${ }^{327}$ capable of converting energy from light into chemical redox energy. A photon with energy equal to or higher than that of the band gap transferred an electron from the VB to the $\mathrm{CB}$ leaving a hole to $\mathrm{VB}$ (cf, enlarged portion of Figure 7). The number of photogenerated electron-hole pairs $\left(\mathrm{e}^{-}-\mathrm{h}^{+}\right)$ depends on the semiconductor band structure and effective intensity and energy of the incident light. The initial process for heterogeneous photocatalysis of organic and inorganic compounds by semiconductors is this photogeneration of $\mathrm{e}^{-}-\mathrm{h}^{+}$pairs in the semiconductor particles. Upon excitation, the fate of the separated electron and hole can follow different pathways. Figure 7 illustrates these de-excitation pathways for the electrons and holes.

In the absence of suitable electron or hole scavenger (adsorbed species as charge carrier trapping site), the charge carriers recombine at the surface (cf, path $\mathrm{A}_{1} / \mathrm{A}_{2}$ of Figure 7) and/or bulk of the semiconductor (cf, path $B$ of Figure 7) to dissipate (heat) energy. On the other hand, when a suitable scavenger is available, the charges migrate to the surface of the $\mathrm{TiO}_{2}$ particle and initiate interfacial redox reaction with the adsorbed species. Thus, $\mathrm{TiO}_{2}$ photosensitizes the reduction of an electron acceptor (A) and the oxidation of an electron donor (D) forming anionic $\left(\mathrm{A}^{-}\right)\left(\mathrm{cf}\right.$, path $\mathrm{C}_{1}$ of Figure 7$)$ and cationic $\left(\mathrm{D}^{+}\right)$(cf, path 


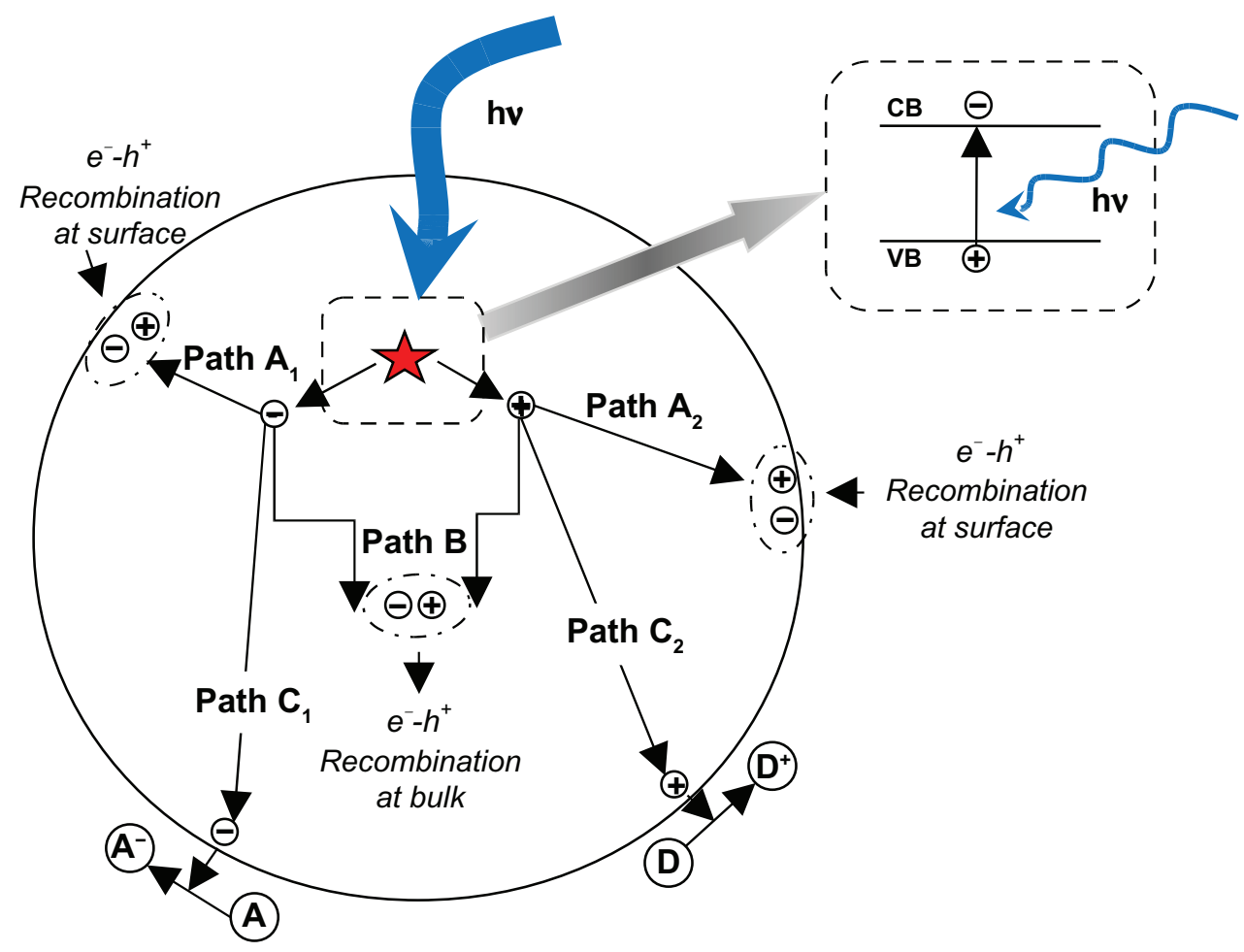

Figure 7 Schematic representation of various de-excitation pathways for photogenerated electron and holes in a $\mathrm{TiO}_{2}$ particle (adapted and redrawn). Kamat PV. Meeting the clean energy demand: nanostructure architectures for solar energy conversion. J Phys Chem C. 2007; I I I (7): 2834-2860.345

Abbreviations: $C B$, conduction band; $V B$, valance band; $h v$, photon energy of frequency $v$.

$\mathrm{C}_{2}$ of Figure 7) species. In nanostructured semiconductors, the surface-to-volume ratio is very high, and hence the reactive surface is also higher in nanomaterial regimes. Therefore, the surface adsorption and interfacial redox reaction can be enhanced by using nanostructured semiconductors. ${ }^{328}$ This semiconductor-assisted redox reaction is at the core of the heterogeneous photocatalysis. Photocatalysis is generally divided into two classes of processes: 1) when the initial photoexcitation occurs in an adsorbate molecule which then interacts with the ground state catalyst substrate, the process is referred to as a catalyzed photoreaction, and 2) when the initial photoexcitation takes place in the catalyst substrate and the photoexcited catalyst then transfers an electron or energy into a ground state molecule, the process is referred to as a sensitized photoreaction. ${ }^{61}$ In the subsequent de-excitation processes, which leads to chemical reactions in the heterogeneous photocatalysis process (as mentioned earlier), the electronic population change in the molecular orbitals leads to the different interactions between one reactive center (a reactive center is a molecule or a surface reactive site) in the excited state and another reactive center in the ground state. Generally, this de-excitation process can take place in two forms: 1) electron transfer and 2) energy transfer. Figure 8 schematically illustrates the different interactions between one reactive center in the excited state and another reactive center in the ground state.

Initially, the donor or acceptor molecules are excited as $\mathrm{D} \rightarrow \mathrm{D}^{*}$ or $\mathrm{A} \rightarrow \mathrm{A}^{*}$, where the asterisk represents the excited state. Next, in the electron transfer process, an electron jumps from an occupied orbital of the donor reactant at ground state (D) to the empty orbital of the acceptor reactant at excited state $\left(\mathrm{A}^{*}\right)$. The electron transfer process requires the overlap between the occupied donor orbital and the empty or half-filled acceptor orbital. The electron transfer results in an ion pair of the donor cation $\left(\mathrm{D}^{+}\right)$and the acceptor anion $\left(\mathrm{A}^{-}\right)$according to the following equation:

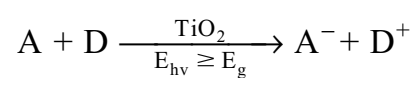

Figure 8A describes the electron transfer from filled ground state donor orbital to half-filled excited acceptor orbital i) or from half-filled excited donor to empty ground state acceptor ii) to form ion pairs $\left(\mathrm{A}^{-}+\mathrm{D}^{+}\right)$. On the other hand, in the energy transfer process, either electron exchange between ground D and excited A* (cf, Figure 8B) or dipole-dipole resonant coupling between ground $\mathrm{D}$ and excited $\mathrm{A}^{*}$ and vice versa (cf, Figure 8C) are considered to be the responsible 


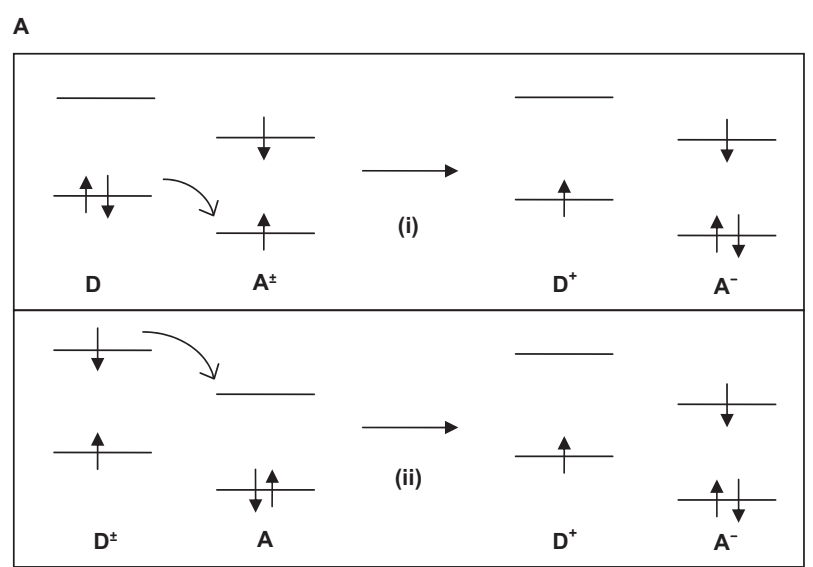

B

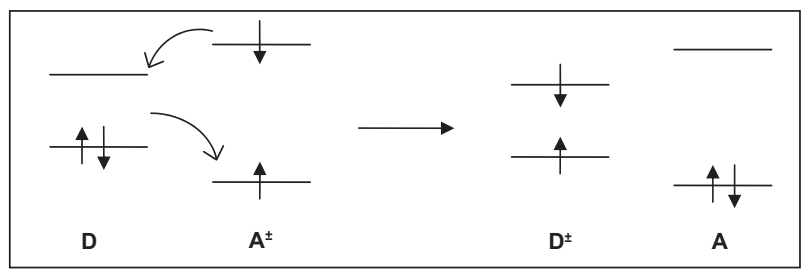

C

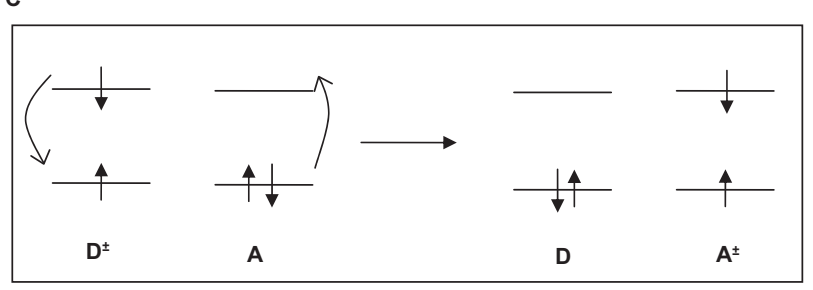

Figure 8 Various electron transfer and energy transfer processes of de-excitation of photogenerated $\mathrm{e}^{-}-\mathrm{h}^{+}$pairs (adapted and redrawn). Kamat PV. Meeting the clean energy demand: nanostructure architectures for solar energy conversion. J Phys Chem C. 2007; I I (7): 2834-2860.345

mechanisms for de-excitation of photogenerated $\mathrm{e}^{-}-\mathrm{h}^{+}$pairs. In the electron exchange process, one electron transfers from the ground state-filled D to half-filled A* coupled with simultaneous transfer of another electron from the upper level of half-filled $A^{*}$ to the empty upper level of D. These two processes occur independently in opposite directions and require simultaneous orbital overlap between the interacting centers. On the other hand, dipole-dipole coupling occurs by a Coulombic resonance interaction in which the oscillating dipole of the excited state molecule, $\mathrm{D}^{*}$, is coupled with the induced dipole in a ground state quencher molecule, A. This coupling process does not require effective orbital overlap between the two interacting centers and can operate over a distance of $0.1-10 \mathrm{~nm}$. A detailed discussion of various electron and energy transfer processes can be found in the literature. ${ }^{329-339}$

The ability of $\mathrm{TiO}_{2}$ to undergo photoinduced electron transfer to adsorbed species on its surface is governed by the band energy positions of the semiconductor and the redox potentials of the adsorbate. Mills and Hunte ${ }^{340}$ discuss band-gap values and the redox (reduction) potential of some oxide and other semiconductor materials with respect to the normal hydrogen electrode (NHE). The $\mathrm{CB}$ electron of $\mathrm{TiO}_{2}$ is a moderate reducing agent $\left(E_{\mathrm{O}} \sim 0.0 \mathrm{~V}\right.$ vs NHE), whereas the oxidizing power of VB hole is very strong $\left(E_{\mathrm{O}} \sim 3.0 \mathrm{~V}\right.$ vs NHE) ${ }^{341}$ Thermodynamically, the redox potentials associated with the $\mathrm{CB}$ and $\mathrm{VB}$ of $\mathrm{TiO}_{2}$ require the relevant potential level of the acceptor species to be below the $\mathrm{CB}$ potential of the $\mathrm{TiO}_{2}$ (ie, more positive), whereas in order to donate an electron to the vacant hole, the potential level of the donor needs to be above the $\mathrm{VB}$ position of $\mathrm{TiO}_{2}$ (ie, more negative). Therefore, assuming no kinetic limitations, $\mathrm{TiO}_{2}$-assisted photoinduced interfacial redox reaction will take place with acceptors and donors whose respective reduction potentials are comprised between $\mathrm{CB}$ and $\mathrm{VB}$ band positions of $\mathrm{TiO}_{2} \cdot{ }^{61,341}$ It is noteworthy that when the $\mathrm{TiO}_{2}$ surface will be under contact with any fluid (gas/liquid) or metal, there will be band bending at the interface due to the redistribution of the charges (and double layer and Schottky barrier formation). For an $n$-type semiconductor like $\mathrm{TiO}_{2}$, the band bending will be in the upward direction. Due to this redistributed band structure at the surface, $\mathrm{e}^{-}-\mathrm{h}^{+}$recombination process will be affected and, hence, modify the photocatalysis activity of $\mathrm{TiO}_{2}$.

Among anatase and rutile crystal structures of $\mathrm{TiO}_{2}$, anatase shows a higher photocatalytic activity. ${ }^{342}$ The structure of rutile and anatase are shown in Figures 3 and 4 and described in Table 1. The two crystal structures differ by the distortion of each octahedron and by the assembly pattern of the octahedra chains. These differences in lattice structures cause different mass densities and electronic band structures between the two forms of $\mathrm{TiO}_{2}$ that lead to different photoactivities of these two structures.

\section{Photolysis on $\mathrm{TiO}_{2}$-solar hydrogen}

Photolysis or photosplitting of water into gaseous $\mathrm{O}_{2}$ and $\mathrm{H}_{2}$ represents one of the most challenging and promising ways of solar energy accumulation, as solar hydrogen can then be used as an alternative fuel. Numerous comprehensive studies ${ }^{343-354}$ have been performed since the first report of photocatalytic water splitting on $\mathrm{TiO}_{2}$ surface was published in $1972 .{ }^{64}$ The band energy position of $\mathrm{TiO}_{2}$ relative to the electrochemical potentials of the $\mathrm{H}_{2} / \mathrm{H}_{2} \mathrm{O}$ and $\mathrm{O}_{2} / \mathrm{H}_{2} \mathrm{O}$ redox couples $^{61,355}$ demonstrates that due to the presence of a large overpotential for the evolution of $\mathrm{H}_{2}$ and $\mathrm{O}_{2}$ on the $\mathrm{TiO}_{2}$ surface, $\mathrm{TiO}_{2}$ alone cannot photodecompose $\mathrm{H}_{2} \mathrm{O}$; rather the 
photoassisted oxidation of the oxygen vacancy sites on a reduced $\mathrm{TiO}_{2}$ surface is responsible for $\mathrm{H}_{2}$ evolution. ${ }^{61,356}$

$\mathrm{TiO}_{2}$-assisted photoelectrolysis of water is achieved using a close circuit photoelectrochemical cell that consists of a $\mathrm{TiO}_{2}$ anode and a Pt counter electrode and is exposed to near-UV light. ${ }^{64,357}$ Generation of the photoelectrochemical $\mathrm{e}^{-}-\mathrm{h}^{+}$pair in $\mathrm{TiO}_{2}$ is followed by the transfer of electron to the Pt electrode and reduction of water molecule to evolve $\mathrm{H}_{2}$ according to the following reaction:

$$
2 \mathrm{H}^{+}+2 \mathrm{e}^{-} \rightarrow \mathrm{H}_{2} \uparrow,
$$

whereas at the anode, water oxidation takes place according to following reaction:

$$
\mathrm{H}_{2} \mathrm{O}+2 \mathrm{~h}^{+} \rightarrow \frac{1}{2} \mathrm{O}_{2} \uparrow+2 \mathrm{H}^{+}
$$

Therefore, the overall photosplitting of water will be given as follows:

$$
\mathrm{H}_{2} \mathrm{O} \underset{\mathrm{TiO}_{2}-\mathrm{Pt}}{\longrightarrow} \mathrm{H}_{2}+\frac{1}{2} \mathrm{O}_{2} \text {. }
$$

Sometimes the system requires some external electrical $(>0.25 \mathrm{~V})$ or chemical (alkali in anode half cell and/or acid in cathode half cell) bias to increase efficiency. ${ }^{320-324,340,357}$

In another variation, solar hydrogen is generated by mixing $\mathrm{TiO}_{2}$ powders with noble metals $(\mathrm{Pt}, \mathrm{Ag}$, and $\mathrm{Au}$ ) and oxide $\left(\mathrm{RuO}_{2}\right)$ particles. Here, this system behaves as a microphotoelectrochemical cell in which the metal $(\mathrm{Pt})$ acts as the cathode and oxide $\left(\mathrm{RuO}_{2}\right)$ as the anode. Band-gap excitation in the $\mathrm{TiO}_{2}$ injects electrons into the Pt particles and holes into the $\mathrm{RuO}_{2}$ particles. Trapped electrons in $\mathrm{Pt}$ reduce water to hydrogen, and trapped holes in $\mathrm{RuO}_{2}$ oxidize water to oxygen. ${ }^{358}$ Various ways of modifying $\mathrm{TiO}_{2}$ particles have been reported, such as metal ion or anion doping, metal ion implantation, dye sensitization, addition of sacrificial or other components to the electrolyte, and so on. However, all these processes produce a very low rate of water splitting. ${ }^{34,346}$ Various measures have been taken to increase the rate of hydrogen evolution over $\mathrm{TiO}_{2}$ surfaces such as using artificial high-power UV light sources and/or nanostructured materials. ${ }^{349}$ However, the energy conversion efficiency on $\mathrm{TiO}_{2}$ was rather low and the reasons for this are 1) fast recombination of photogenerated electrons and holes, 2) fast backward reaction, 3) inability to harvest visible and IR light at longer wavelengths than $\sim 400 \mathrm{~nm}$, and 4) less effective surface area. ${ }^{344}$

\section{Surface modification of the $\mathrm{TiO}_{2}$ nanostructure}

Apart from photosplitting of water, other photochemical activities of $\mathrm{TiO}_{2}$ include adsorption and desorption of $\mathrm{O}_{2}$, $\mathrm{CO}_{2}, \mathrm{CO}$, halides, or various organic compounds on nanostructured $\mathrm{TiO}_{2}$ surface ${ }^{359-373}$ and photo-oxidation/reduction of molecular nitrogen, $\mathrm{NO}_{2}, \mathrm{NH}_{3}, \mathrm{CO}_{2}$, or halides. ${ }^{374-389}$ Photocatalysis being a surface phenomenon, surface area is very important in determining the amount of reaction sites, and charge carriers have to be utilized properly to improve their ability to initiate surface reactions. On the other hand, $\mathrm{TiO}_{2}$ crystallinity should be high to prevent the recombination of $\mathrm{e}^{-}$and $\mathrm{h}^{+}$. Highly crystalline $\mathrm{TiO}_{2}$ prevents the recombination of charge carriers relative to amorphous and less crystalline $\mathrm{TiO}_{2}$. As mentioned earlier, because the energy conversion efficiency on $\mathrm{TiO}_{2}$ depends on several factors such as surface area, $\mathrm{e}^{-}-\mathrm{h}^{+}$recombination rates, solar energy spectrum, and so on, as a working hypothesis, surface area, and crystallinity of the $\mathrm{TiO}_{2}$ powder have to be improved for efficient photocatalysis.

Modification of the surface area of $\mathrm{TiO}_{2}$ is performed by using nanostructured materials. Nanoparticulate electrodes are commonly used for these purposes, which consist of a several micrometer-thick film consisting of a random 3-dimensional network of interconnected $15-20 \mathrm{~nm}$ particles. While these electrodes possess a high surface-to-volume ratio, the structural disorder at the contact between two crystalline particles leads to an enhanced scattering of free electrons, thus reducing the electron mobility. ${ }^{390}$ On the other hand, the nanotube array architecture, being ordered and strongly interconnected, eliminates randomization of the grain network and increases contact points for good electrical connection. The nanotube arrays have a large internal surface area and can be easily filled with fluids, thus enabling higher contact with electrolytes. The porosity of the ordered structure allows the incident photons to be more effectively absorbed than on a flat electrode. ${ }^{328}$ Details of the fabrication processes of various nanostructured $\mathrm{TiO}_{2}$ have been discussed previously. Most of these processes used calcination/annealing steps for liquidphase syntheses or elevated-temperature gas-phase syntheses methods to obtain high crystalline $\mathrm{TiO}_{2}$ nanostructures for improved photocatalytic activities.

\section{Doping in nanostructured $\mathrm{TiO}_{2}$ for improved photoactivity}

Doping of $\mathrm{TiO}_{2}$ nanostructures is another method of improving photoactivities of $\mathrm{TiO}_{2}$. Loading of $\mathrm{TiO}_{2}$ surface with 
noble metals and/or metal oxides $\left(\mathrm{RuO}_{2}, \mathrm{ZnO}, \mathrm{WO}_{3}, \mathrm{SnO}_{2}\right)$ creates low-energy states within $\mathrm{TiO}_{2}$ that trap photogenerated charge carriers and thus prevent charge recombination which increases the photoactivity of $\mathrm{TiO}_{2}$. On the other hand, substitutional doping is very important for reducing the band gap of $\mathrm{TiO}_{2}$ nanostructures to utilize the wider fraction of solar radiation, especially the visible and near infrared (NIR) parts. ${ }^{391}$ Much effort has been expended to narrow the $\mathrm{TiO}_{2}$ band gap by compositional doping. According to the crystal structure of $\mathrm{TiO}_{2}$, it appears that replacement of $\mathrm{Ti}^{4+}$ with any cation is relatively easier than to substitute $\mathrm{O}^{2-}$ with any other anion due to the difference in the charge states and ionic radii. Cationic doping of $\mathrm{TiO}_{2}$ with transition and rare earth metals (such as $\mathrm{Cu}, \mathrm{Zr}, \mathrm{Zn}, \mathrm{Co}, \mathrm{Ni}, \mathrm{Cr}, \mathrm{Mn}, \mathrm{Mo}, \mathrm{Nb}, \mathrm{V}$, Fe, Ru, W, Sb, Sn, Au, Ag, Pt, La, Ce, Er, Pr, Gd, Nd, or Sm) has been extensively studied. ${ }^{177,392-405}$ While several authors have reported that transition metal ion doping decreases the photothreshold energy of $\mathrm{TiO}_{2}$, there is also an increase in thermal instability and a decrease in carrier lifetimes, ${ }^{398,399}$ which limits overall conversion efficiencies.

For nonmetal doping of $\mathrm{TiO}_{2}$ in anionic site (oxygen), wide varieties of anionic species $(\mathrm{N}, \mathrm{S}, \mathrm{C}, \mathrm{B}, \mathrm{P}, \mathrm{I}$, or F) have been used. This approach consists of substitution of a nonmetal atom for oxygen. ${ }^{152,405-419}$ The methods used to introduce the dopants include wet-chemical, electrochemical, and physical methods, which have been described in detail in the previous sections and related references. ${ }^{420-425}$ Theoretical calculations show that band-gap narrowing originates from the electronic perturbations caused by the change of lattice parameters and/or by the presence of the trap states within conduction and valence bands of $\mathrm{TiO}_{2}{ }^{426,427}$ Although there is wide consensus that anionic doping produces enhancement in the visible activity of $\mathrm{TiO}_{2}$ photocatalysts, it is a matter of debate whether this anionic doping is really achieving the necessary band-gap narrowing in $\mathrm{TiO}_{2}$ to the extent to be really useful in practical applications. ${ }^{328}$ Recent studies showed that the visible light activity of $\mathrm{TiO}_{2}$ can be further enhanced by codoping of suitable combination of metals and/or nonmetal ions. ${ }^{405,418,419,428-43}$

Nanocomposites of $\mathrm{TiO}_{2}$ with semiconductors having lower band-gap energy such as $\mathrm{CdS}, \mathrm{CdSe}, \mathrm{CdTe}$, $\mathrm{PbS}, \mathrm{Bi}_{2} \mathrm{~S}_{3}, \mathrm{CuInS}_{2}$, and so on, which absorb light in the visible region of solar spectrum, can serve as sensitizers because they are able to transfer electrons to large band gap of $\mathrm{TiO}_{2} \cdot{ }^{144,286,288,291-294,328,432-435}$ However, fabrication of metal-chalcogenite/metal oxide $\left(\mathrm{TiO}_{2}\right)$ composite is somewhat challenging as oxygen intercalation to the chalcogenite sites may alter the band gap of the system and deteriorate photoactivity. Alternatively, metal oxides, such as $\mathrm{CuO}$, $\mathrm{Cu}_{2} \mathrm{O}, \mathrm{Fe}_{2} \mathrm{O}_{3}, \mathrm{WO}_{3}, \mathrm{MoO}_{3}, \mathrm{ZnO}, \mathrm{SnO}_{2}$, and so on, have been considered for band-gap engineering of $\mathrm{TiO}_{2}$ as these oxides have compatible processing strategies with $\mathrm{TiO}_{2} \cdot{ }^{297,328,436-444}$ Among these oxides, low band-gap $\mathrm{CuO}$ or $\mathrm{Cu}_{2} \mathrm{O}$ are used as sensitizers to use visible radiation, whereas other large band-gap oxides (eg, $\mathrm{ZnO}, \mathrm{SnO}_{2}$ ) are coupled with $\mathrm{TiO}_{2}$ for extrinsic trapping of photogenerated charge carriers to enhance photoactivity. Among these, coupling $\mathrm{TiO}_{2}$ with $\mathrm{SnO}_{2}$ attracts much attention. The band gaps of $\mathrm{SnO}_{2}$ and $\mathrm{TiO}_{2}$ are 3.88 and $3.2 \mathrm{eV}$, respectively, and the CB edge of $\mathrm{SnO}_{2}$ is $\sim 0.5 \mathrm{~V}$ above that of $\mathrm{TiO}_{2}$. When the two semiconductor particles are coupled, the $\mathrm{CB}$ of $\mathrm{SnO}_{2}$ acts as a sink for photogenerated electrons. Since the photogenerated holes move in the opposite direction, they accumulate in the VB of the $\mathrm{TiO}_{2}$ particle, which increases the efficiency of charge separation. Recently, a nanocomposite of $\mathrm{TiO}_{2}$ (anatase)/CNT has been reported to show enhanced photoreactivity by reducing charge recombination at $\mathrm{TiO}_{2}$ surface. ${ }^{299,302-306}$ It has been observed that single-walled (SW) CNTs can more effectively reduce the charge recombination rate than that of multiwalled (MW) CNTs as the contact area for $\mathrm{SWCNT} / \mathrm{TiO}_{2}$ is much higher than that of $\mathrm{MWCNT} / \mathrm{TiO}_{2}$ (cf, Figure 9A), enhancing

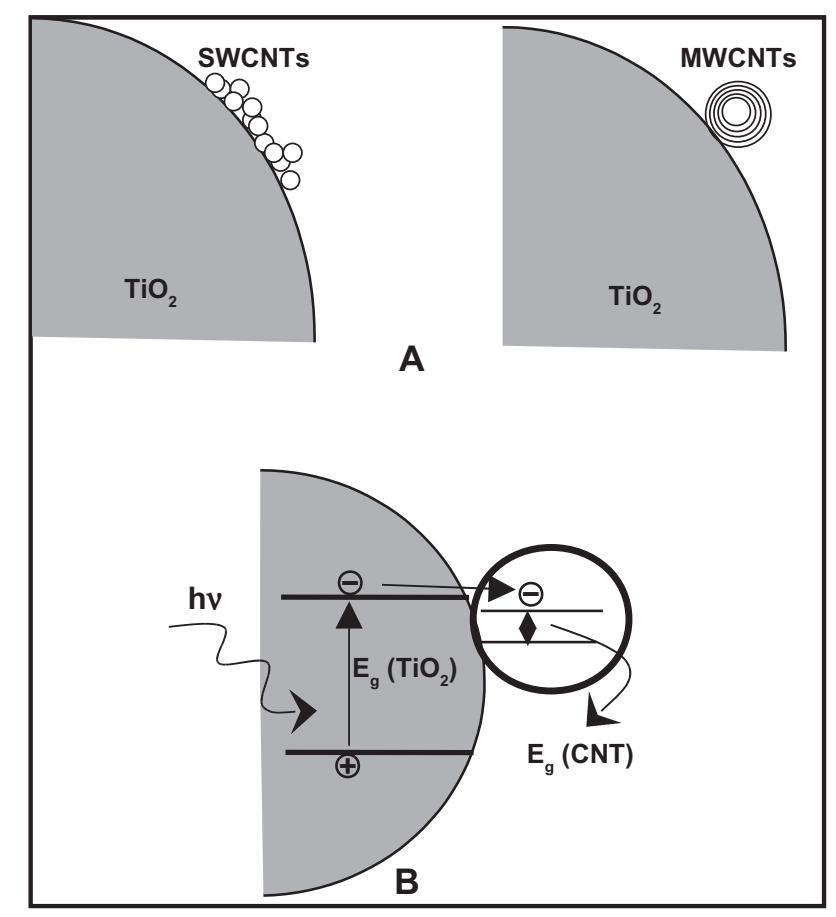

Figure 9 Schematic representation of TiO2/SWCNT and TiO2/MWCNT nanocomposite structures, (b)proposed model for reduction in photogenerated electro-hole recombination in TiO2/CNT nanocomposites (adapted and redrawn). Schnitzler DC, Zarbin AJG. Organic/inorganic hybrid materials formed from TiO2 nanoparticles and polyaniline. J Braz Chem Soc. 2004; I5(3):378-384. ${ }^{315}$

Abbreviations: CNT, carbon nanotubes; MW, multiwall; SW, single wall. 
the charge transfer. ${ }^{299} \mathrm{~A}$ simple mechanism has been proposed by Yao and colleagues ${ }^{299}$ to qualitatively explain the reduced charge recombination rate in $\mathrm{TIO}_{2} / \mathrm{CNT}$ nanocomposite (Figure 9B). Physically, the $\mathrm{CB}$ edge of $\mathrm{TiO}_{2}$ is $-4.21 \mathrm{eV}$ lower than vacuum level with a band gap around $3.2 \mathrm{eV}$, whereas work function of (SWCNT) is $-4.8 \mathrm{eV}$ (with respect to vacuum level), with a narrow band gap ranging from 0.0 to $1.1 \mathrm{eV}^{445}$ Due to this relative position of $\mathrm{CB}$ edges between $\mathrm{TiO}_{2}$ and CNTs, the probability of transfer of the (photogenerated) electrons to the CNTs becomes much higher, leading to a higher lifetime for holes, which consequently enhances its photocatalytic activities.

\section{$\mathrm{TiO}_{2}$-based DSSCs}

DSSCs have attracted much interest as regenerative low-cost alternatives to conventional solid-state devices due to high energy conversion efficiency and the possibility of large scale production. ${ }^{388,352,446}$ A DSSC consists of a nanoporous film prepared from nanoparticles of a wide-gap metal oxide (typically $\mathrm{TiO}_{2}$ ) covered with a monolayer of photosensitizer molecules (a dye, typically ruthenium complexes anchored to the $\mathrm{TiO}_{2}$ surface by a carboxylate bipyridyl ligand) and an electrolyte as a hole transport layer containing redox couples (iodide/tri-iodide). The cell is illuminated through a transparent conducting oxide (TCO) electrode (typically ITO-coated glass) where the semiconductor is deposited. The $\mathrm{TiO}_{2}$ pores are filled with the redox electrolyte which acts as the mediator and establishes electrical contacts with a redox catalyst in the counter electrode. ${ }^{447-451}$ The dyes on the surface of the films absorb light and inject electrons into the $\mathrm{CB}$ of the metal oxide. To collect the electrons at a TCO layer, the electrons should travel the distance in the CB from the point where the electrons were injected to the TCO before recombination. A schematic representation of a typical DSSC is shown in Figure 10. Photoexcitation of the dye (sensitizer) is followed by electron injection into the $\mathrm{CB}$ of the $\mathrm{TiO}_{2}$ nanostructure. The dye molecule is regenerated by the redox system, which itself is regenerated at the counter electrode by passing electrons through the load. Potentials are referred to the NHE. The open-circuit voltage of the solar cell corresponds to the

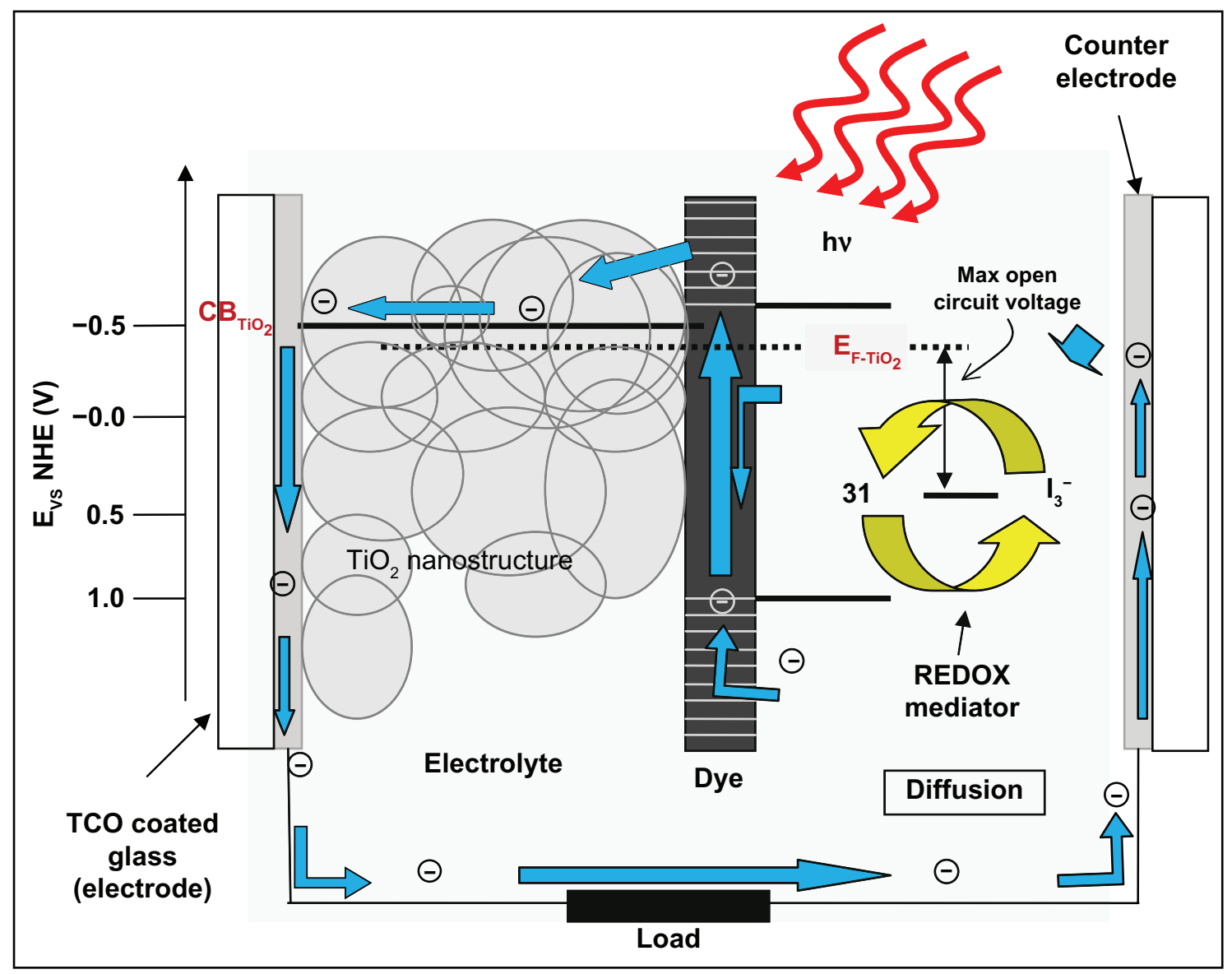

Figure 10 Schematic representation of principle of operation and energy level scheme of the dye-sensitized nanocrystalline solar cell (adapted and redrawn). Luo $\mathrm{H}$, Takata $\mathrm{T}$, Lee Y, Zhao J, Domen K, Yan Y. Photocatalytic activity enhancing for titanium dioxide by co-doping with bromine and chlorine. Chem Mater. 2004;16(5):846-849.482 Note: The diagram is not drawn to the scale. 
difference between the redox potential of the mediator and the Fermi level of the nanocrystalline $\mathrm{TiO}_{2}$ indicated with a dashed line. In the nanoporous $\mathrm{TiO}_{2}$ film, the surface is surrounded by more cations than the electrons, and therefore, it has been assumed that no large electric field gradient is present within the film; hence, the electron transport mechanism is considered to be purely diffusive. ${ }^{452-454}$

DSSCs differ from solid-state $\mathrm{p}-\mathrm{n}$ junction for the fact that light absorption and the transport occur separately. The process is described through equations $7 \mathrm{a}$ through $7 \mathrm{~d}: 449$

$$
\begin{gathered}
\text { Sensitizer }(\mathrm{S})+\mathrm{hv} \rightarrow \mathrm{S}^{*}(\text { excited }) \\
\mathrm{S}^{*}+\mathrm{TiO}_{2} \rightarrow \mathrm{e}^{-}\left(\mathrm{TiO}_{2}\right)+\text { Oxidized sensitizer } \\
\text { Oxidized sensitizer }{ }^{+}+\frac{3}{2} \mathrm{I}^{-} \rightarrow \mathrm{S}+\frac{1}{2} \mathrm{I}_{3}^{-} \\
\frac{1}{2} \mathrm{I}_{3}^{-}+\mathrm{e}^{-}(\text {Counter electrode }) \rightarrow \frac{3}{2} \mathrm{I}^{-}
\end{gathered}
$$

The light absorption takes place in a monolayer of the photosensitizer (S), which is chemically adsorbed on the surface of $\mathrm{TiO}_{2}$ (Eq. 7a). The photoexcited dye ( $\left.\mathrm{S}^{*}\right)$ is then able to transfer electrons into $\mathrm{TiO}_{2}$ (Eq. $7 \mathrm{~b}$ ), which moves toward TCO electrode through the $\mathrm{TiO}_{2}$ porous network. Electrons lost by the sensitizer are recovered using the reduced species present in the electrolyte $\left(\mathrm{I}^{-}\right)($Eq. $7 \mathrm{c})$. Finally, the circuit is closed by the oxidized species of the mediator $\left(\mathrm{I}_{3}^{-}\right)$that obtains electrons which flows through the counter electrode through the load (Eq. 7d).

\section{Other photocatalytic applications of nanostructured $\mathrm{TiO}_{2}$}

Other photocatalytic activities of $\mathrm{TiO}_{2}$ involve photosensitized oxidation of organic pollutants using $\mathrm{TiO}_{2}$ for environmental remediation, wastewater treatment, recovery of precious metal via $\mathrm{TiO}_{2}$-assisted reduction, ${ }^{325,326,340,341,455-457}$ organic synthesis, ${ }^{458}$ photokilling activity, ${ }^{146,356,459,460}$ or selfcleaning activity. ${ }^{340,356}$ Photosensitized oxidation of organic pollutants in the aqueous and gaseous phases can be done according to the following reaction:

$$
\begin{gathered}
\text { Organic compound }+\mathrm{O}_{2} \frac{\mathrm{hv}}{\mathrm{TiO}_{2}-\mathrm{Pt}} \\
\mathrm{CO}_{2}+\mathrm{H}_{2} \mathrm{O}+\text { Mineral acid }
\end{gathered}
$$

Similarly, $\mathrm{TiO}_{2}$-assisted organic syntheses comprise 1) oxidation of alkenes substituted with phenyl groups to yield corresponding ketones

$$
\left[\begin{array}{l}
\mathrm{Ph} \\
\mathrm{Ph}
\end{array} \succ=\mathrm{CH} \underset{\mathrm{CH}_{\mathrm{c}} \mathrm{CN} / \mathrm{O}_{2}}{\longrightarrow} \underset{\mathrm{Ph}}{\mathrm{Ph}} \succ=\mathrm{O}\right]
$$

2) oxidation of substituted toluene to corresponding acetaldehyde and carboxylic acid, and 3) amine intra $\mathrm{N}$-alkylation. ${ }^{340}$ On the other hand, the biggest success of $\mathrm{TiO}_{2}$-based photochemistry is probably the self-cleaning and related phenomena. For example, photoactive $\mathrm{TiO}_{2}$ coated on ceramic or glass undergoes a dual action, ${ }^{340}$ where on one hand $\mathrm{TiO}_{2}$-assisted photo-oxidation takes place to break down the organic compounds (cf, Eq. 8); on the other hand, simultaneous $\mathrm{TiO}_{2}$-assisted, UV-photoinduced superamphiphilicity (forcing detachment of dust and/or organics) takes place followed by a quick drying process. ${ }^{356,461}$ Photoinduced superamphiphilicity of $\mathrm{TiO}_{2}$ exhibits high quantum yield at low UV radiation intensities and, therefore, can be exploited efficiently within an indoor setup when illuminated with conventional fluorescent light. Major glass and ceramic manufacturers have already commercialized self-actuating materials based on this superamphiphilicity of $\mathrm{TiO}_{2}$ in automobile and/or bathroom mirrors, or selfcleaning windows/panels. ${ }^{462,463}$

\section{Conclusions}

A comprehensive review of the properties, fabrication, and application of nanostructured $\mathrm{TiO}_{2}$ has been presented in detail, especially the syntheses procedures of $0-, 1-$, and quasi2-dimensional nanostructures of $\mathrm{TiO}_{2}$ via various physical and chemical techniques. Synthesis strategies regarding nanocomposites of $\mathrm{TiO}_{2}$ with other inorganic and organic materials and applications of $\mathrm{TiO}_{2}$ in terms of photocatalytic activities has been reviewed. The basic mechanisms of photoactivities of $\mathrm{TiO}_{2}$ and nanostructures were explored. The characteristics of band-structure engineering and surface modification in nanostructured $\mathrm{TiO}_{2}$ in the context of doping, including elemental and compound materials doping as well as nanocomposite formation with various inorganic/organic materials were discussed. The nanostructured $\mathrm{TiO}_{2}$-assisted photocatalytic energy/fuel generations in terms of solar hydrogen and/or DSSCs have also been discussed in detail. Other photochemical activities of nanostructured $\mathrm{TIO}_{2}$ such as wastewater treatment, organic synthesis, photokilling, and self-cleaning activities have also been discussed briefly. $\mathrm{TiO}_{2}$ nanomaterials are of tremendous interest in a wide range of applications such as photocatalysis, DSSCs, gas sensors, photochromic devices, photodegradation of organic compounds, deactivation of microorganisms, organic synthesis, and cell culture. 
It will not be an exaggeration to say that the next decade will see the renaissance of $\mathrm{TiO}_{2}$-based nanomaterials, and various new, interesting, and novel technological applications are on the verge of exploration.

\section{Future directions}

In recent years, $\mathrm{TiO}_{2}$-based photocatalytic oxidation of organic compounds has received the most attention, but there is a rapidly increasing focus on the oxidation of volatile organic or inorganic compounds in the gas phase, including $\mathrm{NO}_{x}$ and $\mathrm{SO}_{x}$. Photocatalytic reductions of organic compounds and metal-containing ions and studies on cell killing and disinfection by illuminated $\mathrm{TiO}_{2}$ have also received increasing attention. The current problem with doped $\mathrm{TiO}_{2}$ is the loss of photoactivity during recycling and long-term storage. Future research should be focused on this issue to obtain sustained photoactivity in the long run. Photoactivity of metal-doped $\mathrm{TiO}_{2}$ under visible light strongly depends on preparation methods. A uniform synthetic strategy is the need of the hour to obtain tailored materials for high-efficient UV-Vis photoresponse. In the case of nonmetal-doped $\mathrm{TiO}_{2}$, the main problem is that its photocatalytic activity under visible light is much lower than that under UV radiation. Therefore, development of new and optimization of the existing photocatalysts exhibiting activity upon visible light with surface characteristics of improved performance and of the high chemical and physical stability are crucial for broader scale utilization of photocatalytic systems in commercial applications. Such materials together with the development of technically applicable self-aligning photocatalytic coating systems adaptable to the major substrates (polymers, glass, ceramics, or metals) will represent a ground-breaking step change in this field, particularly in the economic viability of a range of potential applications. One of the major challenges for the scientific and industrial community involved in photocatalytic research is to increase the spectral sensitivity of $\mathrm{TiO}_{2}$-based photocatalysts to visible and NIR regions. A major area of future research should be the development of new nanostructures of $\mathrm{TiO}_{2}$ with higher surface states, new commercially viable nano- $\mathrm{TiO}_{2}$ fabrication methodology, especially nonlithographic complementary metal-oxide-semiconductor compatible techniques for practical applications, new doping materials, new methods for dopant incorporation into $\mathrm{TiO}_{2}$ nanostructure, as well as new applications for environmental technology. Future research should deal with visible-to-NIRactivated $\mathrm{TiO}_{2}$ functioning in the presence of solar irradiation with predictable photoactivity. Finally, a recent report discusses the photocatalytic cancer-cell treatment using
$\mathrm{TiO}_{2}$ nanoparticle, ${ }^{186}$ which opens up a very important field in nanobiotechnology for defective cell treatment. Very few groups have studied the biocompatibility of nanostructured $\mathrm{TiO}_{2} \cdot{ }^{464-469}$ Since nanostructured $\mathrm{TiO}_{2}$ is extensively used in various applications such as dope, dyes, ceramics, cosmetics, and medicine, where contact with human and/or living cells is necessary, the study of the biocompatibility and biosafety of nano- $\mathrm{TiO}_{2}$ should be considered a very important area of future research.

\section{Disclosure}

The authors report no conflicts of interest in this work.

\section{References}

1. Efros AlL, Efros AL. Interband absorption of light in a semiconductor sphere. Sov Phys Semicond. 1982;16:772-775.

2. Brus LE. Electron-electron and electron-hole interactions in small semiconductor crystallites: the size dependence of the lowest excited electronic state. J Chem Phys. 1984;80:4403-4409.

3. Cox AJ, Louderback JG, Bloomfield LA. Experimental observation of magnetism in rhodium clusters. Phys Rev Lett. 1993;71(6): 923-926.

4. Alivisatos AP. Semiconductor clusters, nanocrystals, and quantum dots. Science. 1996;271(5251):933-937.

5. Heath JR. The chemistry of size and order on a nanometer scale. Science. 1995;270(5240):1315-1316.

6. Feynman RP. There's Plenty of Room at the Bottom. Available from: http://www.zyvex.com/nanotech/feynman.html. Accessed 2010 Jun 1.

7. Demel T, Heitmann D, Grambow P, et al. Coupling of quantum dots on GaAs. Phys Rev Lett. 1990:64(21):2559-2562.

8. Li Q, Wang C. Fabrication of wurtzite $\mathrm{ZnS}$ nanobelts via simple thermal evaporation. Appl Phys Lett. 2003;83(2):359-362.

9. Demel T, Heitmann D, Grambow P, Ploog K. One-dimensional plasmons in AlGaAs/GaAs quantum wires. Phys Rev Lett. 1991;66(20): 2657-2660.

10. Banerjee AN, Chattopadhyay KK. Recent developments in the emerging field of crystalline p-type transparent conducting oxide thin films. Prog Cryst Growth Charac Mater. 2005;50(1-3):52-105.

11. Klein DL, Roth R, Lim AKL, Alivisatos AP, McEuen PL. A singleelectron transistor made from a cadmium selenide nanocrystal. Nature. 1997;389(6652):699-701.

12. Feldheim DL, Keating CD. Self-assembly of single electron transistors and related devices. Chem Soc Rev. 1998;27(1):1-12.

13. Tsuda N, Nasu K, Yanase A, Siratori K. Electronic Conduction in Oxides. Berlin, Germany: Springer-Verlag; 1991.

14. Rao CNR, Raveau B. Transition Metal Oxides. 2nd ed. New York, NY: Wiley/VCH; 1998.

15. Moulson AJ, Herbert JM. Electroceramics. 2nd ed. London, UK: Chapman and Hall; 1990.

16. Cox PA. Transition Metal Oxides. Oxford, UK: Oxford University Press; 1992.

17. Henrich VE, Cox PA. The Surface Science of Metal Oxides. Cambridge, UK: Cambridge University Press; 1994.

18. Noguera C. Physics and Chemistry at Oxide Surfaces. Cambridge, UK: Cambridge University Press; 1996.

19. Fukuyama H, Nagaosa N, editors. Physics and Chemistry of Transition Metal Oxides. Berlin, Germany: Springer; 1999.

20. Vegard L. Results of crystal analysis. Philos Mag. 1916;32: 505-515.

21. Cronemeyer DC. Electrical and optical properties of rutile single crystals. Phys Rev. 1952;87(5):876-886. 
22. Breckenridge RG, Hosler WR. Electrical properties of titanium dioxide semiconductors. Phys Rev. 1953;91(4):793-802.

23. Johnson GH. Influence of impurities on electrical conductivity of rutile. J Am Ceram Soc. 1953;36(3):97-101.

24. Cronemeyer DC. Infrared absorption of reduced rutile $\mathrm{TiO}_{2}$ single crystals. Phys Rev. 1959;113(5):1222-1226.

25. Grant FA. Properties of rutile (titanium dioxide). Rev Mod Phys. 1959;31(3):646-674.

26. Frederikse HPR. Recent studies on rutile $\left(\mathrm{TiO}_{2}\right)$. J Appl Phys. 1961; 32(10):2211-2215.

27. Barbanel VI, Bogomolov VN. Diffusion and defects in rutile during its partial reduction in a vacuum. Sov Phys Solid State. 1970;11: 2160-2161.

28. Kofstad P. Note on the defect structure of rutile $\left(\mathrm{TiO}_{2}\right)$.J Less Common Met. 1967;13(6):635-638.

29. Henzler M, Göpel W. Oberfächenphysik des Festkörpers. 2nd ed. Stuttgard (Germany): Teubner; 1994.

30. Ardakani HK. Electrical and optical properties of in situ "hydrogenreduced" titanium dioxide thin films deposited by pulsed excimer laser ablation. Thin Solid Films. 1994;248(2):234-239.

31. Bogomolov VN, Kudinov EK, Mirlin DN, Firsov YA. Sov Phys Solid State. 1968;9:1630-1633.

32. Bogomolov VN, Firsov YA, Kudinov EK, Mirlin DN. On the experimental observation of small polarons in rutile $\left(\mathrm{TiO}_{2}\right)$. Phys Stat Sol B. 1969;35(2):555-558.

33. Agekyan VT, Stepanov YA. Sov Phys Solid State. 1976;17: 2390-2393.

34. Klinger MI. On the experimental observation of small polarons in semiconductors. Phys Stat Sol B. 1968;27(2):479-488.

35. Tang H. Electronic Properties of Anatase $\mathrm{TiO}_{2}$ Investigated by Electrical and Optical Measurements on Single Crystals and Thin Films. Lausanne, France: Département de physique, Ecole polytechnique fédérale de Lausanne EPFL; 1994.

36. O'Regan B, Grätzel M. A low-cost, high-efficiency solar cell based on dye-sensitized colloidal $\mathrm{TiO}_{2}$ films. Nature. 1991;353(6346): 737-740.

37. Berger H, Tang H, Lévy F. Growth and Raman spectroscopic characterization of $\mathrm{TiO}_{2}$ anatase single crystals. J Cryst Growth. 1993;130(1-2): $108-112$.

38. Tang H, Prasad K, Sanjinés R, Schmid PE, Lévy F. Electrical and optical properties of $\mathrm{TiO}_{2}$ anatase thin films. J Appl Phys. 1994;75(4): 2042-2047.

39. Sanjinés R, Tang H, Berger H, Gozzo F, Margaritondo G, Lévy F. Electronic structure of anatase $\mathrm{TiO}_{2}$ oxide. J Appl Phys. 1994;75(6): 2945-2951.

40. Tang H, Lévy F, Berger H, Schmid PE. Urbach tail of anatase $\mathrm{TiO}_{2}$. Phys Rev B Condens Matter. 1995;52(11):7771-7774.

41. Hosaka N, Sekiya T, Satoko C, Kurita S. Optical properties of singlecrystal anatase $\mathrm{TiO}_{2}$. J Phys Soc Jpn. 1997;66:877-880.

42. Sekiya T, Igarashi M, Kurita S, Takekawa S, Fujisawa M. Structure dependence of reflection spectra of $\mathrm{TiO}_{2}$ single crystals. $J$ Electron Spectrosc Relat Phenom. 1998;92(1-3):247-250.

43. Sekiya T, Ichimura K, Igarashi M, Kurita S. Absorption spectra of anatase $\mathrm{TiO}_{2}$ single crystals heat-treated under oxygen atmosphere. J Phys Chem Solids. 2000;61(8):1237-1242.

44. Sittig CE. Charakterisierung der Oxidschichten auf Titan und Titanlegierungen sowie deren Reaktionen in Kontakt mit biologisch relevanten Modellösungen. Zürich, Switzerland: Eidgenössische Technische Hochschule ETHZ; 1998.

45. Clark W, Broadhead P. Optical absorption and photochromism in irondoped rutile. J Phys C Solid State Phys. 1970;3(5):1047-1050.

46. Layman P. Outlook brightens for titanium dioxide following recent business pickup. Chem Eng News. 1996;74(4):13-14.

47. Radecka M, Zahrzewska K, Czternastek H, Stapiński T, Debrus S. The influence of thermal annealing on the structural, electrical and optical properties of $\mathrm{TiO}_{2-x}$ thin films. Appl Surf Sci. 1993;65-66(2): $227-234$
48. Lee $\mathrm{S}$, Park BH, Oh SG. In-situ ellipsometric investigation of $\mathrm{TiO}_{2}$ thin-film initial growth. J Korean Phys Soc. 1997;31(2):352-356.

49. Thelen AJ. Design of Optical Interference Coatings. New York, NY: McGraw Hill; 1989.

50. MacLeod HA. Thin-Film Optical Filters. Bristol, UK: Adam Hiliger Ltd; 2001.

51. Siefering KL, Griffin GL. Growth kinetics of $\mathrm{CVD} \mathrm{TiO}_{2}$ : influence of carrier gas. J Electrochem Soc. 1990;137(4):1206-1208.

52. Harris AW, Ludden BP, Blaikley DCW. The production of titania thin film waveguides by de reactive magnetron sputtering. Vacuum. 1992; 43(1-2):143-147.

53. Orignac X, Vasconcelos HC, Du XM, Almeida RM. Influence of solvent concentration on the microstructure of $\mathrm{SiO}_{2}-\mathrm{TiO}_{2}$ sol-gel films. $J$ Sol Gel Sci Technol. 1997;8(1-3):243-248.

54. Satake K, Katayama A, Ohkoshi H, Nakahara T, Takeuchi T. Titania $\mathrm{NO}_{x}$ sensors for exhaust monitoring. Sens Actuators B Chem. 1994; 20(2-3):111-117.

55. Tang H, Prasad K, Sanjinés R, Lévy F. $\mathrm{TiO}_{2}$ anatase thin films as gas sensors. Sens Actuators B Chem. 1995;26(1-3):71-75.

56. Baraton MI, Merhari L, Wang J, Gonsalves KE. Investigation of the $\mathrm{TiO}_{2} / \mathrm{PPV}$ nanocomposite for gas sensing applications. Nanotechnology. 1998;9(4):356-359.

57. Dai G. A study of the sensing properties of thin film sensor to trimethylamine. Sens Actuators B Chem. 1998;53(1-2):8-12.

58. Gao L, Li Q, Song Z, Wang J. Preparation of nano-scale titania thick film and its oxygen sensitivity. Sens Actuators B Chem. 2000;71(3): 179-183.

59. Frank SN, Bard AJ. Heterogeneous photocatalytic oxidation of cyanide ion in aqueous solutions at titanium dioxide powder. $\mathrm{J} \mathrm{Am} \mathrm{Chem} \mathrm{Soc.}$ 1977;99:303-304.

60. Sakata T, Kawai T. Heterogeneous photocatalytic production of hydrogen and methane from ethanol and water. Chem Phys Lett. 1981;80(2): 341-344.

61. Linsebigler AL, Lu G, Yates JT Jr. Photocatalysis on $\mathrm{TiO}_{2}$ surfaces: principles, mechanisms, and selected results. Chem Rev. 1995;95(3): 735-758.

62. Ying JY, Sun T. Research needs assessment on nanostructured catalysts. J Electroceram. 1997;1(3):219-238.

63. Dumitriu D, Bally AR, Ballif C, et al. Photocatalytic degradation of phenol by $\mathrm{TiO}_{2}$ thin films prepared by sputtering. Appl Catal B. 2000; 25(2-3):83-92.

64. Fujishima A, Honda K. Electrochemical photolysis of water at a semiconductor electrode. Nature. 1972;238(5358):37-38.

65. Ohko Y, Hashimoto K, Fujishima A. Kinetics of photocatalytic reactions under extremely low-intensity UV illumination on titanium dioxide thin films. J Phys Chem A. 1997;101(43):8057-8062.

66. Grätzel M, Kalyanasundaram K. Artificial photosynthesis: efficient dye-sensitized photoelectrochemical cells for direct conversion of visible light to electricity. Curr Sci. 1994;66:706-714.

67. Bonhôte P, Moser JE, Vlachopoulos N, et al. Photoinduced electron transfer and redox-type photochromism of a $\mathrm{TiO}_{2}$-anchored molecular diad. Chem Commun. 1996;(10):1163-1164.

68. Siebentritt S, Ernst K, Fischer $\mathrm{CH}$, et al. CdTe and CdS as extremely thin absorber materials in an eta solar cell (ETA). 14th European Photovoltaic Solar Energy Conference. Barcelona, Spain; 1997.

69. Tennakone K, Kumara GRRA, Kottegoda IRM, Perera VPS, Aponsu GMLP. Nanoporous n- $\mathrm{TiO}_{2} /$ selenium/p-CuCNS photovoltaic cell. J Phys D Appl Phys. 1998;31(18):2326-2330.

70. Möller J, Fischer CH, Siebentritt S, et al. $\mathrm{CuInS}_{2}$ as an extremely thin absorber in an eta solar cell. Proceedings of the 2nd World Conference and Exhibition on Photovoltaic Solar Energy Conversion. Vienna; 1998.

71. Tatsuma T, Saitoh S, Ohko Y, et al. $\mathrm{TiO}_{2}-\mathrm{WO}_{3}$ photoelectrochemical anticorrosion system with an energy storage ability. Chem Mater. 2001; $13: 2838-2842$

72. Wang R, Hashimoto K, Fujishima A, et al. Light-induced amphiphilic surfaces. Nature. 1997;388:431-432. 
73. Bally AR, Prasad K, Sanjinés R, et al. $\mathrm{TiO}_{2}$ : $\mathrm{Ce} / \mathrm{CeO}_{2}$ high performance insulators for thin film electroluminescent devices. Mater Res Soc Symp. 1996;424:471-475.

74. Vullers RJM, Ahlskog M, van Haesendonck C. Titanium nanostructures made by local oxidation with the atomic force microscope. Appl Surf Sci. 1999;144-145:584-588.

75. Matsumoto K, Takahashi S, Ishii M, et al. Application of STM nanometer-size oxidation process to planar-type mim diode. Jpn J Appl Phys. 1995;34(2B):1387-1390.

76. Ohko Y, Tatsuma T, Fuji T, et al. Multicolor photochromism of $\mathrm{TiO}_{2}$ films loaded with silver nanoparticles. Nat Mater. 2003;2(1):29-31.

77. Ohko Y, Tatsuma T, Fuji T, et al. Multicolor photochromism of $\mathrm{TiO}_{2}$ films loaded with Ag nanoparticles. ECS, Electrochemical Society, 203rd Meeting. Paris; 2003.

78. Bunshah RF. Deposition Technologies for Films and Coatings: Developments and Applications. 1st ed. Park Ridge: Noyes Publications; 1982.

79. Jarzebski ZM. Oxide Semiconductors. 1st ed. New York, NY: Pergamon Press; 1973.

80. Kofstad P. Nonstoichiometry, Diffusion, and Electrical Conductivity in Binary Metal Oxides. New York, NY: John Wiley and Sons, Inc; 1983.

81. Chen X, Mao SS. Titanium dioxide nanomaterials: synthesis, properties, modifications, and applications. Chem Rev. 2007;107(7): 2891-2959.

82. Springer S. Free carriers in nanocrystalline titanium dioxide thin films. Ecole polytechnique fédérale de Lausanne EPFL. Lausanne; 2004: Thèse no 2934.

83. Diebold U. The surface science of titanium dioxide. Surf Sci Rep. 2003;48(5-8):53-229.

84. JCPDS, International Centre for Diffraction Data (ICDD). PDF-database. Available from: http://www.icdd.com. Accessed 2010 Nov 8.

85. Banfield JF, Bischoff $\mathrm{BL}$, Anderson $\mathrm{MA}$. $\mathrm{TiO}_{2}$ accessory minerals: coarsening, and transformation kinetics in pure and doped synthetic nanocrystalline materials. Chem Geol. 1993;110(1-3):211-231.

86. Simons PY, Dachille F. The structure of $\mathrm{TiO}_{2} \mathrm{II}$, a high-pressure phase of $\mathrm{TiO}_{2}$. Acta Crystallogr. 1967;23(2):334-336.

87. Tang J, Endo J. $\mathrm{P}-\mathrm{T}$ boundary of $\alpha-\mathrm{PbO}_{2}$ type and baddeleyite type high-pressure phases of titanium dioxide. J Am Ceram Soc. 1993; 76(3):796-798.

88. Olsen JS, Gerward L, Jiang JZ. On the rutile/ $\alpha-\mathrm{PbO}_{2}$-type phase boundary of $\mathrm{TiO}_{2}$. J Phys Chem Solids. 1999;60(2):229-233.

89. Latroche M, Brohan R, Marchand R, Tournoux M. New hollandite oxides: $\mathrm{TiO}_{2}(\mathrm{H})$ and $\mathrm{K}_{0.06} \mathrm{TiO}_{2}$. J Solid State Chem. 1989;81(1):78-82.

90. Akimoto J, GotohY, Oosawa Y, et al. Topotactic oxidation of ramsdellitetype $\mathrm{Li}_{0.5} \mathrm{TiO}_{2}$, a new polymorph of titanium dioxide: $\mathrm{TiO}_{2}(\mathrm{R}) . J$ Solid State Chem. 1994;113(1):27-36.

91. Marchand R, Brohan R, Tournoux $\mathrm{M} \mathrm{TiO}_{2}(\mathrm{~B})$ a new form of titanium dioxide and the potassium octatitanate $\mathrm{K}_{2} \mathrm{Ti}_{8} \mathrm{O}_{17}$. Mater Res Bull. 1980; 15(8):1129-1133.

92. Haines J, Leger JM. X-ray diffraction study of $\mathrm{TiO}_{2}$ up to $49 \mathrm{GPa}$. Physica B. 1993;192(3):233-237.

93. Horn M, Schwerdtfeger CF, Meagher EP. Refinement of the structure of anatase at several temperatures. Z Kristallogr. 1972;136:273-281.

94. Henrich VE. The surfaces of metal oxides. Rep Prog Phys. 1985; 48(11):1481.

95. Thien-Nga L, Paxton AT. Electronic structure of $5 d$ transition metals adsorbed on the stoichiometric (110) rutile surface. Phys Rev B. 1998; 58(19):13233-13241.

96. Wyckoff RWG. Crystal Structures Handbook. 2nd ed. New York, NY: Interscience Publishers; 1963.

97. Wahlbeck PG, Gilles PW. Reinvestigation of the phase diagram for the system titanium-oxygen. J Am Ceram Soc. 1966;49(4):180-183.

98. Kihlborg L, Olovsson I. Arne Magnéli, 1914-1996. Acta Crystallogr A. 1997;53:103-104.

99. Straumanis ME, Ejima T, James WJ. The $\mathrm{TiO}_{2}$ phase explored by the lattice constant and density method. Acta Crystallogr. 1961;14: 493-497.
100. Carnahan RD, Brittain JO. Optical absorption study of the reduction kinetics of rutile crystals. J Am Ceram Soc. 1965;48(7): 365-369.

101. Cronemeyer DC, Gilleo MA. The optical absorption and photoconductivity of rutile. Phys Rev. 1951;82(6):975-976.

102. Hosaka N, Sekiya T, Fujisawa M, Satoko C, Kurita S. UV reflection spectra of anatase $\mathrm{TiO}_{2}$. J Electron Spectros Relat Phenom. 1996;78: 75-78.

103. Jellison GA Jr, Modine FA, Boatner LA. Measurement of the optical functions of uniaxial materials by two-modulator generalized ellipsometry: rutile $\left(\mathrm{TiO}_{2}\right)$. Opt Lett. 1997;22(23):1808-1810.

104. Palik ED, editor. Handbook of Optical Constants of Solids. Orlando, FL: Academic Press; 1985.

105. Washburn EW. International Critical Tables of Numerical Data, Physics, Chemistry and Technology. New York, NY: McGraw-Hill; 1930.

106. Tanemura S, Miao L, Jin P, Kaneko K, Terai A, Nabatova-Gabain N. Optical properties of polycrystalline and epitaxial anatase and rutile $\mathrm{TiO}_{2}$ thin films by rf magnetron sputtering. Appl Surf Sci. 2003; 212-213:654-660.

107. Cangiani G. Ab Initio Study of the Properties of TiO Rutile and Anatase Polytypes. Lausanne, France: Faculté des sciences de base, Ecole polytechnique fédérale de Lausanne EPFL; 2003.

108. Paxton AT, Thien-Nga L. Electronic structure of reduced titanium dioxide. Phys Rev B. 1998;57(3):1579-1584.

109. Bally A. Electronic Properties of Nanocrystalline Titanium Dioxide Thin Films. Lausanne, France: Département de physique, Ecole polytechnique fédérale de Lausanne EPFL; 1999.

110. Knauth P, Tuller HL. Electrical and defect thermodynamic properties of nanocrystalline titanium dioxide. J Appl Phys. 1999;85(2): 897-902.

111. Mizushima K, Tanaka M, Asai A, Iida S, Goodenough GB. Impurity levels of iron-group ions in TiO2(II). J Phys Chem Solids. 1979; 40(12):1129-1140.

112. Forro L, Chauvet O, Emin D, Zuppiroli L, Berger H, Lévy F. High mobility $n$-type charge carriers in large single crystals of anatase $\left(\mathrm{TiO}_{2}\right.$ ). J Appl Phys. 1994;75(1):633-635.

113. Yu N, Halley JW. Electronic structure of point defects in rutile $\mathrm{TiO}_{2}$. Phys Rev B. 1995;51(8):4768-4776.

114. Blumenthal RN, Coburn J, Baukus J, Hirthe WM. Electrical conductivity of nonstoichiometric rutile single crystals from $1000^{\circ}$ to $1500^{\circ} \mathrm{C}$. J Phys Chem Solids. 1966;27(4):643-654.

115. Martin N, Santo AME, Sanjinés R, Lévy F. Energy distribution of ions bombarding $\mathrm{TiO}_{2}$ thin films during sputter deposition. Surf Coat Technol. 2001;138(1):77-83.

116. Bogomolov VN, Kudinov EK, Mirlin DN, et al. Polaron mechanism of light absorption in rutile crystals. Sov Phys Solid State. 1963;9:1630-1639.

117. Becker JH, Hosler WR. Multiple-band conduction in $n$-type rutile $\left(\mathrm{TiO}_{2}\right.$ ). Phys Rev A. 1965;137(6A):1872-1877.

118. Hasiguti RR, Yagi E. Electrical conductivity below $3 \mathrm{~K}$ of slightly reduced oxygen-deficient rutile $\mathrm{TiO}_{2-x^{*}}$. Phys Rev B. 1994;49(11): 7251-7256.

119. Mott NF. Electrons in disordered structures. Adv Phys. 1967;16(61): 49-144.

120. Enright B, Fitzmaurice D. Spectroscopic determination of electron and hole effective masses in a nanocrystalline semiconductor film. J Phys Chem. 1996;100(3):1027-1035.

121. Nozik AJ, Memming R. Physical chemistry of semiconductor-liquid interfaces. J Phys Chem. 1996;100(31):13061-13078.

122. Grela MA, Brusa Ma, Colussi AJ. Harnessing excess photon energy in photoinduced surface electron transfer between salicylate and illuminated titanium dioxide nanoparticles. J Phys Chem B. 1997; 101(51):10986-10989.

123. Okuyama K, Kousaka Y, Tohge N, et al. Production of ultrafine metal oxide aerosol particles by thermal decomposition of metal alkoxide vapors. AIChE J. 1986;32(12):2010-2019. 
124. Okuyama K, Jeung JT, Kousaka Y. Experimental control of ultrafine $\mathrm{TiO}_{2}$ particle generation from thermal decomposition of titanium tetraisopropoxide vapor. Chem Eng Sci. 1989;44(6):1369-1375.

125. Okuyama K, Ushio R, Kousaka Y, Flagan RC, Seinfeld JH. Particle generation in a chemical vapor deposition process with seed particles. AIChE J. 1990;36(3):409-419.

126. Ding Z, Hu X, Lu GQ, Yue P-L, Greenfield PF. Novel silica gel supported $\mathrm{TiO}_{2}$ photocatalyst synthesized by CVD method. Langmuir. 2000;16(15):6216-6222.

127. Li W, Shah SI, Huang C-P, Jung O, Ni C. Metalorganic chemical vapor deposition and characterization of $\mathrm{TiO}_{2}$ nanoparticles. Mater Sci Eng B. 2002;96(3):247-253.

128. Li W, Shah SI, Sung M, et al. Structure and size distribution of $\mathrm{TiO}_{2}$ nanoparticles deposited on stainless steel mesh. J Vac Sci Technol B 2002;20(6):2303-2308.

129. Li W, Wang $\mathrm{Y}$, Lin $\mathrm{H}$, et al. Band gap tailoring of $\mathrm{Nd}^{3+}$-doped $\mathrm{TiO}_{2}$ nanoparticles. Appl Phys Lett. 2003;83(20):4143-4415.

130. Leboda R, Gun'ko VM, Marciniak M, et al. Structure of chemical vapor deposition titania/silica gel. J Colloid Interface Sci. 1999; 218(1):23-39.

131. Gun'ko VM, Zarko VI, Turov VV, et al. CVD-titania on fumed silica substrate. J Colloid Interface Sci. 1998;198(1):141-156.

132. Schrijnemakers K, Impens NREN, Vansant EF. Deposition of a titania coating on silica by means of the chemical surface coating. Langmuir. 1999;15(18):5807-5813.

133. Stakheev AY, Lee CW, Chong PJ. Preparation and characterization of titanium dioxide embedded onto ZSM-5 zeolite. Bull Korean Chem Soc. 1998;19(5):530-533.

134. Xia B, Li W, Zhang B, Xie Y. Low temperature vapor-phase preparation of $\mathrm{TiO}_{2}$ nanopowders. J Mater Sci. 1999;34(14):3505-3511.

135. Mezey EJ. Pigments and reinforcing agents. In: Powell CF, Oxley JH, Blocher JM Jr, editors. Vapor Deposition. New York, NY: John Wiley and Sons; 1966:423.

136. Akhtar MK, Pratsinis SE, Mastrangelo SVR. Dopants in vaporphase synthesis of titania powders. J Am Ceram Soc. 1992;75(12): 3408-3416.

137. Suyama $\mathrm{Y}$, Kato A. $\mathrm{TiO}_{2}$ produced by vapor-phase oxygenolysis of TiCI. J Am Ceram Soc. 1976;59(3-4):146-149.

138. Vemury S, Pratsinis SE, Kibbey L. Electrically controlled flame synthesis of nanophase $\mathrm{TiO}_{2}, \mathrm{SiO}_{2}$, and $\mathrm{SnO}_{2}$ powders. J Mater Res. 1997;12(4):1031-1042.

139. Vemury S, Pratsinis SE. Corona-assisted flame synthesis of ultrafine titania particles. Appl Phys Lett. 1995;66:3275-3278.

140. Casey JD, Haggerty JS. Laser-induced vapour-phase synthesis of titanium dioxide. J Mater Sci. 1987;22(12):4307-4312.

141. Epperson JE, Siegel RW, White JW, et al. Sintering of nanophase $\mathrm{TiO}_{2}$ at $550^{\circ}$ C. Mater Res Soc Symp Proc. 1988;132:3-7.

142. Kato A, Takeshima Y, Katatae Y. Preparation of spherical titania particles from inorganic precursor by homogeneous precipitation. Mater Res Soc Symp Proc. 1989;155:13-15.

143. Choi W, Termin A, Hoffmann MR. The role of metal ion dopants in quantum-sized $\mathrm{TiO}_{2}$ : correlation between photoreactivity and charge carrier recombination dynamics. J Phys Chem. 1994;98(51):13669-13679.

144. Yu JC, Wu L, Lin J, Li P, Li Q. Microemulsion-mediated solvothermal synthesis of nanosized CdS-sensitized $\mathrm{TiO}_{2}$ crystalline photocatalyst. Chem Commun. 2003;13:1552-1553.

145. Schneider M, Baiker A. High-surface-area titania aerogels: preparation and structural properties. J Mater Chem. 1992;2:587-589.

146. Zhang AP, Sun YP. Photocatalytic killing effect of $\mathrm{TiO}_{2}$, nanoparticles on Ls-174-t human colon carcinoma cells. World J Gastroenterol. 2004;10(21):3191-3193.

147. Chen LX, Rajh T, Wang Z, Thurnauer MC. XAFS studies of surface structures of $\mathrm{TiO}_{2}$ nanoparticles and photocatalytic reduction of metal ions. J Phys Chem B. 1997;101(50):10688-10697.

148. Wang CC, Zhang Z, Ying JY. Photocatalytic decomposition of halogenated organics over nanocrystalline titania. Nanostruct Mater. 1997;9(1-8):583-586.
149. Xue Q, Liu W, Zhang Z. Friction and wear properties of a surfacemodified $\mathrm{TiO}_{2}$ nanoparticle as an additive in liquid paraffin. Wear. 1997;213(1-2):29-32.

150. Jeon S, Braun PV. Hydrothermal synthesis of Er-doped luminescent $\mathrm{TiO}_{2}$ nanoparticles. Chem Mater. 2003;15(6):1256-1263.

151. Liqiang J, Xiaojun S, Baifu X, Baiqi W, Weimin C, Honggang F. The preparation and characterization of $\mathrm{La}$ doped $\mathrm{TiO}_{2}$ nanoparticles and their photocatalytic activity. J Solid State Chem. 2004;177(10): 3375-3382.

152. Burda C, Lou YB, Chen XB, Samia ACS, Stout J, Gole JL. Enhanced nitrogen doping in $\mathrm{TiO}_{2}$ nanoparticles. Nano Lett. 2003; 3(8):1049-1051.

153. Zhang Z, Wang CC, Zakaria R, Ying JY. Role of particle size in nanocrystalline $\mathrm{TiO}_{2}$-based photocatalysts. J Phys Chem B. 1998; 102(52):10871-10878.

154. Sugimoto T, Zhou X, Muramatsu A. Synthesis of uniform anatase $\mathrm{TiO}_{2}$ nanoparticles by gel-sol method. 3. Formation process and size control. J Colloid Interface Sci. 2003;259(1): 43-52.

155. Stathatos E, Lianos P, Del-Monte F, Levy D, Tsiourvas D. Formation of $\mathrm{TiO}_{2}$ nanoparticles in reverse micelles and their deposition as thin films on glass substrates. Langmuir. 1997; 13(16):4295-4300.

156. Sakai H, Kawahara H, Shimazaki M, Abe M. Preparation of ultrafine titanium dioxide particles using hydrolysis and condensation reactions in the inner aqueous phase of reversed micelles: effect of alcohol addition. Langmuir. 1998;14(8):2208-2212.

157. Haga Y, An H, Yosomiya R. Photoconductive properties of $\mathrm{TiO}_{2}$ films prepared by the sol-gel method and its application. JMater Sci. 1997;32(12):3183-3188.

158. Li K, Wang Y, Sun Y, Yuan C. Preparation of nanocrystalline $\mathrm{TiO}_{2}$ electrode by layer-by-layer screen printing and its application in dye-sensitized solar cell. Mater Sci Eng B. 2010;175(1): 44-47.

159. Xu C, Killmeyer R, Gray ML, Khan SUM. Photocatalytic effect of carbon-modified $n$ - $\mathrm{TiO}_{2}$ nanoparticles under visible light illumination. Appl Catal B. 2006;64(3-2):312-317.

160. Jagadale TC, Takale SP, Sonawane RS, et al. N-doped $\mathrm{TiO}_{2}$ nanoparticle based visible light photocatalyst by modified peroxide sol-gel method. J Phys Chem C. 2008;112(37):14595-14602.

161. Shen GX, Chen YC, Lin CJ. Corrosion protection of $316 \mathrm{~L}$ stainless steel by a $\mathrm{TiO}_{2}$ nanoparticle coating prepared by sol-gel method. Thin Solid Films. 2005;489(1-2):130-136.

162. Zaban A, Aruna ST, Tirosh S, Gregg BA, Mastai Y. The effect of the preparation condition of $\mathrm{TiO}_{2}$ colloids on their surface structures. J Phys Chem B. 2000;104(17):4130-4133.

163. Oskam G, Nellore A, Penn RL, Searson PC. The growth kinetics of $\mathrm{TiO}_{2}$ nanoparticles from titanium(IV) alkoxide at high water/titanium ratio. J Phys Chem B. 2003;107(8):1734-1738.

164. Wu M, Lin G, Chen D, et al. Sol-hydrothermal synthesis and hydrothermally structural evolution of nanocrystal titanium dioxide. Chem Mater. 2002;14(5):1974-1980.

165. Pottier A, Chaneac C, Tronc E, Mazerolles L, Jolivet JP. Synthesis of brookite $\mathrm{TiO}_{2}$ nanoparticles by thermolysis of $\mathrm{TiCl}_{4}$ in strongly acidic aqueous media. J Mater Chem. 2001;11:1116-1121.

166. Aruna ST, Tirosh S, Zaban A. Nanosize rutile titania particle synthesis via a hydrothermal method without mineralizers. J Mater Chem. 2000; 10(10):2388-2391.

167. Wang CC, Ying JY. Sol-gel synthesis and hydrothermal processing of anatase and rutile titania nanocrystals. Chem Mater. 1999;11(11): 3113-3120.

168. Yin H, Wada Y, Kitamura T, et al. Hydrothermal synthesis of nanosized anatase and rutile $\mathrm{TiO}_{2}$ using amorphous phase $\mathrm{TiO}_{2} . J$ Mater Chem. 2001;11(6):1694-1703.

169. Park NG, van de Lagemaat J, Frank AJ. Comparison of dyesensitized rutile- and anatase-based $\mathrm{TiO}_{2}$ solar cells. J Phys Chem B. 2000;104(38):8989-8994. 
170. Wang W, Gu B, Liang L, Hamilton WA, Wesolowski DJ. Synthesis of rutile $\left(\alpha-\mathrm{TiO}_{2}\right)$ nanocrystals with controlled size and shape by low-temperature hydrolysis: effects of solvent composition. J Phys Chem B. 2004;108(39):14789-14792.

171. Li JG, Ishigaki T, Sun X. Anatase, brookite, and rutile nanocrystals via redox reactions under mild hydrothermal conditions: phase-selective synthesis and physicochemical properties. J Phys Chem C. 2007; 111(13):4969-4976.

172. Koelsch M, Cassaignon S, Thanh Minh CT, Guillemoles JF, Jolivet JP. Electrochemical comparative study of titania (anatase, brookite and rutile) nanoparticles synthesized in aqueous medium. Thin Solid Films. 2004;451-452:86-92.

173. Tomita K, Petrykin V, Kobayashi M, Shiro M, Yoshimura M, Kakihana M. A water-soluble titanium complex for the selective synthesis of nanocrystalline brookite, rutile, and anatase by a hydrothermal method. Angew Chem Int Ed Engl. 2006;45(15):2378-2381.

174. Reyes-Coronado D, Rodríguez-Gattorno G, Espinosa-Pesqueira ME, Cab C, de Coss R, Oskam G. Phase-pure $\mathrm{TiO}_{2}$ nanoparticles: anatase, brookite and rutile. Nanotechnology. 2008;19:145605 (10pp).

175. Wang Y, Cheng H, Hao Y, Ma J, Li W, Cai S. Preparation, characterization and photoelectrochemical behaviors of $\mathrm{Fe}(\mathrm{III})$-doped $\mathrm{TiO}_{2}$ nanoparticles. J Mater Sci. 1999;34(15):3721-3729.

176. Cheng H, Ma J, Zhao Z, Qi L. Hydrothermal preparation of uniform nanosize rutile and anatase particles. Chem Mater. 1995;7(4): 663-671.

177. Wang Y, Hao Y, Cheng H, et al. The photoelectrochemistry of transition metal-ion-doped $\mathrm{TiO}_{2}$ nanocrystalline electrodes and higher solar cell conversion efficiency based on $\mathrm{Zn}^{2+}$-doped $\mathrm{TiO}_{2}$ electrode. J Mater Sci. 1999;34(12):2773-2779.

178. Rao AR, Dutta V. Low-temperature synthesis of $\mathrm{TiO}_{2}$ nanoparticles and preparation of $\mathrm{TiO}_{2}$ thin films by spray deposition. Solar Energy Mater Solar Cells. 2007;91(12):1075-1080.

179. Palmisano L, Augugliaro V, Sclafani A, Schiavello M. Activity of chromium-ion-doped titania for the dinitrogen photoreduction to ammonia and for the phenol photodegradation. J Phys Chem. 1988; 92(23):6710-6713.

180. Akhtar MK, Xiong Y, Pratsinis SE. Vapor synthesis of titania powder by titanium tetrachloride oxidation. AIChE J. 1991;37(10): 1561-1570.

181. Shi L, Li C, Chen A, Zhu Y, Fang D. Morphology and structure of nanosized $\mathrm{TiO}_{2}$ particles synthesized by gas-phase reaction. Mater Chem Phys. 2000;66(1):51-57.

182. Gao Y, Masuda Y, Seo WS, Ohta H, Koumoto K. TiO nanoparticles prepared using an aqueous peroxotitanate solution. Ceram Int. 2004;30(7):1365-1368.

183. Mahshid S, Ghamsari MS, Askari M, Afshar N, Lahuti S. Synthesis of $\mathrm{TiO}_{2}$ nanoparticles by hydrolysis and peptization of titanium isopropoxide solution. Semiconductor Phys Quantum Electron Optoelectron. 2006;9(2):65-68.

184. Vorkapic D, Matsoukas T. Effect of temperature and alcohols in the preparation of titania nanoparticles from alkoxides. J Am Ceram Soc. 1998;81(11):2815-2820.

185. Li XL, Peng Q, Yi JX, Wang X, Li Y. Near monodisperse $\mathrm{TiO}_{2}$ nanoparticles and nanorods. Chem Eur J. 2006;12(8):2383-2391.

186. Seo JW, Chung H, Kim MY, Lee J, Choi IH, Cheon J. Development of water-soluble single-crystalline $\mathrm{TiO}_{2}$ nanoparticles for photocatalytic cancer-cell treatment. Small. 2007;3(5):850-853.

187. Teleki A, Pratsinis SE, Kalyanasundaram K, Gouma PI. Sensing of organic vapors by flame-made $\mathrm{TiO}_{2}$ nanoparticles. Sens Actuators $B$ Chem. 2006;119(2):683-690.

188. Yager P, Schoen PE. Formation of tubules by a polymerizable surfactant. P Mol Cryst Liq Cryst. 1984;106:371-381.

189. Iijima S. Helical microtubules of graphitic carbon. Nature. 1991;354: 56-58.

190. Martin CR. Nanomaterials: a membrane-based synthetic approach. Science. 1994;266(5193):1961-1966.
191. Adachi M, Murata Y, Harada M, Yoshikawa S. Formation of titania nanotubes with high photo-catalytic activity. Chem Lett. 2000;29(8): 942-944.

192. Zhou YK, Cao L, Zhang FB, He BL, Li HL. Lithium insertion into $\mathrm{TiO}_{2}$ nanotube prepared by the hydrothermal process. J Electrochem Soc. 2003;150(9):A1246-A1249.

193. Poulios I, Kositzi M, Kouras A. Photocatalytic decomposition of triclopyr over aqueous semiconductor suspensions. J Photochem Photobiol A Chem. 1998;115(2):175-183.

194. Adachi M, Okada I, Ngamsinlapasathian S, Murata Y, Yoshikawa S. Dye-sensitized solar cells using semiconductor thin film composed of titania nanotubes. Electrochemistry. 2002;70(6): 449-452.

195. Uchida S, Chiba R, Tomiha M, Masaki N, Shirai M. Application of titania nanotubes to a dye-sensitized solar cell. Electrochemistry. 2002; $70(6): 418-420$.

196. Quan X, Yang S, Ruan X, Zhao H. Preparation of titania nanotubes and their environmental applications as electrode. Environ Sci Technol. 2005;39(10):3770-3775.

197. Hoyer P. Formation of a titanium dioxide nanotube array. Langmuir. 1996;12(6):1411-1413.

198. Kasuga T, Hiramatsu M, Hoson A, Sekino T, Niihara K. Formation of titanium oxide nanotube. Langmuir. 1998;14(12):3160-3163.

199. Kasuga T, Hiramatsu M, Hoson A, Sekino T, Niihara K. Titania nanotubes prepared by chemical processing. Adv Mater. 1999;11(15): 1307-1311.

200. Zhu Y, Li H, Koltypin Y, Hacohen YR, Gedanken A. Sonochemical synthesis of titania whiskers and nanotubes. Chem Commun (Camb). 2001;24:2616-2617.

201. Du GH, Chen Q, Che RC, Yuan ZY, Peng LM. Preparation and structure analysis of titanium oxide nanotubes. Appl Phys Lett. 2001; 79(22):3702-3704.

202. Seo DS, Lee JK, Kim H. Preparation of nanotube-shaped $\mathrm{TiO}_{2}$ powder. J Cryst Growth. 2001;229(1-4):428-432.

203. Zhang QH, Gao L, Sun J, Zheng S. Preparation of long $\mathrm{TiO}_{2}$ nanotubes from ultrafine rutile nanocrystals. Chem Lett. 2002;31(2): 226-227.

204. Armstrong AR, Armstrong G, Canales J, Garcia R, Bruce PG. Lithiumion intercalation into $\mathrm{TiO}_{2}-\mathrm{B}$ nanowires. Adv Mater. 2005;17(7): 862-865.

205. Yao BD, Chan YF, Zhang XY, Zhang WF, Yang ZY, Wang N. Formation mechanism of $\mathrm{TiO}_{2}$ nanotubes. Appl Phys Lett. 2003;82(2): 281-283.

206. Wu Z, Dong F, Zhao W, Wang H, Liu Y, Guan B. The fabrication and characterization of novel carbon doped $\mathrm{TiO}_{2}$ nanotubes, nanowires and nanorods with high visible light photocatalytic activity. Nanotechnology. 2009;20(23):235701.

207. Zhang YX, Li GH, Jin YX, Zhang Y, Zhang J, Zhang LD. Hydrothermal synthesis and photoluminescence of TiO nanowires. Chem Phys Lett. 2002;365(3-4):300-304.

208. Jitputti J, Suzuki Y, Yoshikawa S. Synthesis of $\mathrm{TiO}_{2}$ nanowires and their photocatalytic activity for hydrogen evolution. Catal Commun. 2008;9(6):1265-1271.

209. Dong F, Zhao W, Wu Z. Characterization and photocatalytic activities of $\mathrm{C}, \mathrm{N}$ and $\mathrm{S}$ co-doped $\mathrm{TiO}_{2}$ with $1 \mathrm{D}$ nanostructure prepared by the nano-confinement effect. Nanotechnology. 2008;19(36): 365607.

210. Feng X, Shankar K, Varghese OK, Paulose M, Latempa TJ, Grimes CA. Vertically aligned single crystal $\mathrm{TiO}_{2}$ nanowire arrays grown directly on transparent conducting oxide coated glass: synthesis details and applications. Nano Lett. 2008;8(11):3781-3786.

211. Kitano M, Mitsui R, Eddy DR, et al. Synthesis of nanowire $\mathrm{TiO}_{2}$ thin films by hydrothermal treatment and their photoelectrochemical properties. Catal Lett. 2007;119(3-4):217-221.

212. Wang D, Zhou F, Wang C, Liu W. Synthesis and characterization of silver nanoparticle loaded mesoporous $\mathrm{TiO}_{2}$ nanobelts. Microporous Mesoporous Mater. 2008;116(1-3):658-664. 
213. Ye Q, Wang X, Hu H, Wang D, Li S, Zhou F. Polyelectrolyte brush templated multiple loading of $\mathrm{Pd}$ nanoparticles onto $\mathrm{TiO}_{2}$ nanowires via regenerative counterion exchange-reduction. J Phys Chem C. 2009; 113(18):7677-7683.

214. Zhang X, Zhang T, Ng J, Sun DD. High-performance multifunctional $\mathrm{TiO}_{2}$ nanowire ultrafiltration membrane with a hierarchical layer structure for water treatment. Adv Funct Mater. 2009;19(23): 3731-3736.

215. Liu B, Aydil ES. Growth of oriented single-crystalline rutile $\mathrm{TiO}_{2}$ nanorods on transparent conducting substrates for dye-sensitized solar cells. J Am Cher Soc. 2009;131(11):3985-3990.

216. Chang M, Lin CH, Deka JR, Chang FC, Chung CC. Nanomechanical characterization of microwave hydrothermally synthesized titania nanowires. J Phys D Appl Phys. 2009;42(14):145105.

217. Wang H, Liu Y, Li M, Huang H, Zhong M, Shen H. Hydrothermal growth of large-scale macroporous $\mathrm{TiO}_{2}$ nanowires and its application in 3D dye-sensitized solar cells. Appl Phys A Mater Sci Process. 2009; 97(1):25-29.

218. Wen B, Liu C, Liu Y. Bamboo-shaped Ag-doped $\mathrm{TiO}_{2}$ nanowires with heterojunctions. Inorg Chem. 2005;44(19):6503-6505.

219. Tian ZR, Voigt JA, Liu J, McKenzie B, Xu H. Large oriented arrays and continuous films of $\mathrm{TiO}_{2}$-based nanotubes. $\mathrm{J}$ Am Chem Soc 2003;125(41):12384-12385.

220. Maiyalagan T, Viswanathan B, Varadaraju UV. Fabrication and characterization of uniform $\mathrm{TiO}_{2}$ nanotube arrays by sol-gel template method. Bull Mater Sci. 2006;29(7):705-708.

221. Lei Y, Zhang LD, Meng GW, et al. Preparation and photoluminescence of highly ordered $\mathrm{TiO}_{2}$ nanowire arrays. Appl Phys Lett. 2001;78(8): $1125-1127$.

222. Lakshmi BB, Patrissi CJ, Martin CR. Sol-gel template synthesis of semiconductor oxide micro- and nanostructures. Chem Mater. 1997; 9(11):2544-2550

223. Lakshmi BB, Dorhout PK, Martin CR. Sol-gel template synthesis of semiconductor nanostructures. Chem Mater. 1997;9(3): $857-862$.

224. Imai H, Takei Y, Shimizu K, Matsuda M, Hirashima H. Direct preparation of anatase $\mathrm{TiO}_{2}$ nanotubes in porous alumina membranes. J Mater Chem. 1999;9(12):2971-2972.

225. Michailowski A, AlMawlawi D, Cheng G, Moskovits M. Highly regular anatase nanotubule arrays fabricated in porous anodic templates. Chem Phys Lett. 2001;349(1-2):1-5.

226. Miao Z, Xu D, Ouyang J, Guo G, Zhao X, Tang Y. Electrochemically induced sol-gel preparation of single-crystalline $\mathrm{TiO}_{2}$ nanowires. Nano Lett. 2002;2(7):717-720.

227. Lin Y, Wu GS, Yuan XY, Xie T, Zhang LD. Fabrication and optical properties of $\mathrm{TiO}_{2}$ nanowire arrays made by sol-gel electrophoresis deposition into anodic alumina membranes. $J$ Phys Condens Matter. 2003;15(17):2917-2922.

228. Zhang XY, Zhang LD, Chen W, Meng GW, Zheng MJ, Zhao LX. Electrochemical fabrication of highly ordered semiconductor and metallic nanowire arrays. Chem Mater. 2001;13(8):2511-2515.

229. Liu S, Huang K. Straightforward fabrication of highly ordered $\mathrm{TiO}_{2}$ nanowire arrays in AAM on aluminum substrate. Solar Energy Mater Solar Cells. 2005;85(1):125-131.

230. Herderick ED, Tresback JS, Vasiliev AL, Padture NP. Templatedirected synthesis, characterization and electrical properties of Au$\mathrm{TiO}_{2}-\mathrm{Au}$ heterojunction nanowires. Nanotechnology. 2007; 18(15): 155204.

231. Caruso RA, Schattka JH, Greiner A. Titanium dioxide tubes from solgel coating of electrospun polymer fibers. Adv Mater. 2001;13(20): $1577-1579$.

232. Formo E, Lee E, Campbell D, Xia Y. Functionalization of electrospun $\mathrm{TiO}_{2}$ nanofibers with $\mathrm{Pt}$ nanoparticles and nanowires for catalytic applications. Nano Lett. 2008;8(2):668-672.

233. Archana PS, Jose R, Vijila C, Ramakrishna S. Improved electron diffusion coefficient in electrospun $\mathrm{TiO}_{2}$ nanowires. J Phys Chem C. 2009;113(52):21538-21542.
234. Jung JH, Kobayashi H, van Bommel KJC, Shinkai S, Shimizu T. Creation of novel helical ribbon and double-layered nanotube $\mathrm{TiO}_{2}$ structures using an organogel template. Chem Mater. 2002;14(4):1445-1447.

235. Kobayashi S, Hanabusa K, Hamasaki N, Kimura M, Shirai H. Preparation of $\mathrm{TiO}_{2}$ hollow-fibers using supramolecular assemblies. Chem Mater. 2000;12(6):1523-1525.

236. Zhang D, Qi L. Synthesis of mesoporous titania networks consisting of anatase nanowires by templating of bacterial cellulose membranes. Chem Commun (Camb). 2005;21:2735-2737.

237. Chen Y, Kim HC, McVittie J, Ting C, Nishi Y. Synthesis of TiO nanoframe and the prototype of a nanoframe solar cell. Nanotechnology. 2010;21(18):185303.

238. Zwilling V, Aucouturier M, Darque-Ceretti E. Anodic oxidation of titanium and TA6V alloy in chromic media. An electrochemical approach. Electrochim Acta. 1999;45(6):921-929.

239. Zwilling V, Darque-Ceretti E, Boutry-Forveille A, David D, Perrin MY, Aucouturier M. Structure and physicochemistry of anodic oxide films on titanium and TA6V alloy. Surf Interface Anal. 1999; 27(7):629-637.

240. Jennings JR, Ghicov A, Peter LM, Schmuki P, Walker AB. Dyesensitized solar cells based on oriented $\mathrm{TiO}_{2}$ nanotube arrays: transport, trapping, and transfer of electrons. J Am Chem Soc. 2008;130(40): 13364-13372.

241. Varghese OK, Gong D, Paulose M, Grimes CA, Dickey EC. Crystallization and high-temperature structural stability of titanium oxide nanotube arrays. $J$ Mater Res. 2003;18(1):156-165.

242. Macák JM, Tsuchiya H, Taveira L, Aldabergerova S, Schmuki P. Smooth anodic $\mathrm{TiO}_{2}$ nanotubes. Angew Chem Int Ed Engl. 2005; 44(45):7463-7465.

243. Gong D, Grimes CA, Varghese OK, Chen Z, Hu W, Dickey EC. Titanium oxide nanotube arrays prepared by anodic oxidation. $J$ Mater Res. 2001;16(12):3331-3334.

244. Macák JM, Tsuchiya H, Ghicov A, Schmuki P. Dye-sensitized anodic $\mathrm{TiO}_{2}$ nanotubes. Electrochem Commun. 2005;7(11):1133-1137.

245. Mor GK, Shankar K, Paulose M, Varghese OK, Grimes CA. Use of highly-ordered $\mathrm{TiO}_{2}$ nanotube arrays in dye-sensitized solar cells. Nano Lett. 2006;6(2):215-218.

246. Paulose M, Shankar K, Varghese OK, Mor GK, Hardin B, Grimes CA. Backside illuminated dye-sensitized solar cells based on titania nanotube array electrodes. Nanotechnology. 2006;17(5): $1446-1448$.

247. Stergiopoulos T, Valota A, Likodimos V, et al. Dye-sensitization of self-assembled titania nanotubes prepared by galvanostatic anodization of Ti sputtered on conductive glass. Nanotechnology. 2009;20(36): 365601 .

248. Stergiopoulos T, Ghicov A, Likodimos V, et al. Dye-sensitized solar cells based on thick highly ordered $\mathrm{TiO}_{2}$ nanotubes produced by controlled anodic oxidation in non-aqueous electrolytic media. Nanotechnology. 2008;19(23):235602.

249. Zhu K, Neale NR, Miedaner A, Frank AJ. Enhanced charge-collection efficiencies and light scattering in dye-sensitized solar cells using oriented $\mathrm{TiO}_{2}$ nanotubes arrays. Nano Lett. 2007;7(1):69-74.

250. Shankar K, Mor GK, Prakasam HE, Varghese OK, Grimes CA. Selfassembled hybrid polymer- $\mathrm{TiO}_{2}$ nanotube array heterojunction solar cells. Langmuir. 2007;23(24):12445-12449.

251. Oh S, Daraio S, Chen LH, Pisanic TR, Fiñones RR, Jin S. Significantly accelerated osteoblast cell growth on aligned $\mathrm{TiO}_{2}$ nanotubes. J Biomed Mater Res A. 2006;78(1):97-103.

252. Paulose $\mathrm{M}$, Prakasam $\mathrm{HE}$, Varghese $\mathrm{OK}$, et al. $\mathrm{TiO}_{2}$ nanotube arrays of $1000 \mu \mathrm{m}$ length by anodization of titanium foil: phenol red diffusion. J Phys Chem C. 2007;111(41):14992-14997.

253. Yu BY, Tsai A, Tsai SP, et al. Efficient inverted solar cells using $\mathrm{TiO}_{2}$ nanotube arrays. Nanotechnology. 2008;19(25):255202.

254. Tsuchiya H, Macák JM, Taveira L, et al. Self-organized $\mathrm{TiO}_{2}$ nanotubes prepared in ammonium fluoride containing acetic acid electrolytes. Electrochem Commun. 2005;7(6):576-580. 
255. Wang J, Zhao L, Lin VSY, Lin Z. Formation of various $\mathrm{TiO}_{2}$ nanostructures from electrochemically anodized titanium. J Mater Chem. 2009;19(22):3682-3687.

256. Kuang D, Brillet J, Chen $\mathrm{P}$, et al. Application of highly ordered $\mathrm{TiO}_{2}$ nanotube arrays in flexible dye-sensitized solar cells. ACS Nano. 2008; 2(6):1113-1116

257. Xia M, Zhang Q, Li H, et al. The large-scale synthesis of onedimensional $\mathrm{TiO}_{2}$ nanostructures using palladium as catalyst at low temperature. Nanotechnology. 2009;20(5):055605.

258. Wu Z, Guo S, Wang H, Liu Y. Synthesis of immobilized $\mathrm{TiO}_{2}$ nanowires by anodic oxidation and their gas phase photocatalytic properties. Electrochem Commun. 2009;11(8):1692-1695.

259. Kang SH, Kim HS, Kim JY, Sung YE. An investigation on electron behavior employing vertically-aligned $\mathrm{TiO}_{2}$ nanotube electrodes for dye-sensitized solar cells. Nanotechnology. 2009;20(35): 355307.

260. Chen Q, Xu D, Wu Z, Liu Z. Free-standing $\mathrm{TiO}_{2}$ nanotube arrays made by anodic oxidation and ultrasonic splitting. Nanotechnology. 2008; 19(36):365708.

261. Yang Y, Wang X, Sun C, Li L. Electron field emission and photoluminescence of anatase nanotube arrays. J Am Ceram Soc. 2008;91(12): 4109-4111.

262. Limmer SJ, Seraji S, Forbess MJ, et al. Electrophoretic growth of lead zirconate titanate nanorods. Adv Mater. 2001;13(16): 1269-1272.

263. Joo SW, Banerjee AN. Field emission characterization of vertically oriented uniformly grown nickel nanorod arrays on metal-coated silicon substrate. J Appl Phys. 2010;107(11):114317.

264. Joo SW, Banerjee AN. FESEM studies of densely-packed aligned nickel nanopillars on silicon substrate by electrochemical deposition through porous alumina membrane. Mater Sci Eng B. 2010;175(1): 36-40.

265. Banerjee A, Halder N. Electrochemical growth of ordered nickel nanorods within a composite structure of anodic-alumina-membrane/metal/ silicon substrate. J Nanosci Nanotechnol. 2010;10(7):4252-4258.

266. Venkataramanan NS, Matsui K, Kawanami H, Ikushima Y. Green synthesis of titania nanowire composites on natural cellulose fibers. Green Chem. 2007;9(1):18-19.

267. Li GL, Wang GH, Hong JM. Synthesis and characterization of rutile $\mathrm{TiO}_{2}$ nanowhiskers. J Mater Res. 1999;14(8):3346-3354.

268. Daothong S, Songmee N, Thongtem S, Singjai P. Size-controlled growth of $\mathrm{TiO}_{2}$ nanowires by oxidation of titanium substrates in the presence of ethanol vapor. Scripta Mater. 2007;57(7):567-570.

269. Kim SW, Han TH, Kim J, et al. Fabrication and electrochemical characterization of $\mathrm{TiO}_{2}$ three-dimensional nanonetwork based on peptide assembly. ACS Nano. 2009;3(5):1085-1090.

270. Sander MS, Cote MJ, Gu W, Kile BM, Tripp CP. Template-assisted fabrication of dense, aligned arrays of titania nanotubes with wellcontrolled dimensions on substrates. Adv Mater. 2004;16(22): 2052-2057.

271. Park J, Ryu Y, Kim H, Yu C. Simple and fast annealing synthesis of titanium dioxide nanostructures and morphology transformation during annealing processes. Nanotechnology. 2009;20(10): 105608 .

272. Wu JM, Xue HX. Photocatalytic active titania nanowire arrays on Ti substrates. J Am Ceram Soc. 2009;92(9):2139-2143.

273. Xiang B, Zhang Y, Wang Z, et al. Field-emission properties of $\mathrm{TiO}_{2}$ nanowire arrays. J Phys D Appl Phys. 2005;38(8):1152-1155.

274. Zhang H, Luo X, Xu J, Xiang B, Yu D. Synthesis of TiO $/ 2 \mathrm{SiO}_{2}$ core/shell nanocable arrays. J Phys Chem B. 2004;108(39):14866-14869.

275. Wu JM, Shih HC, Wu WT, Tseng YK, Chen IC. Thermal evaporation growth and the luminescence property of $\mathrm{TiO}_{2}$ nanowires. J Cryst Growth. 2005;281(2-4):384-390.

276. Wu JM, Shih HC, Wu WT. Growth of $\mathrm{TiO}_{2}$ nanorods by two-step thermal evaporation. J Vac Sci Technol B Microelectron Nanometer Struct Process Meas Phenom. 2005;23(5):2122-2126.
277. Wu JM, Shih HC, Wu WT. Electron field emission from single crystalline $\mathrm{TiO}_{2}$ nanowires prepared by thermal evaporation. Chem Phys Lett. 2005;413(4-6):490-494.

278. Wu JM, Shih HC, Wu WT. Formation and photoluminescence of single-crystalline rutile $\mathrm{TiO}_{2}$ nanowires synthesized by thermal evaporation. Nanotechnology. 2006;17(1):105-109.

279. Wolcott A, Smith WA, Kuykendall TR, Zhao Y, Zhang JZ. Photoelectrochemical water splitting using dense and aligned $\mathrm{TiO}_{2}$ nanorod arrays. Small. 2009;5(1):104-111.

280. Oota T, Yamai I. Vapor phase growth of titania whiskers by hydrolysis of titanium flouride. J Cryst Growth. 1984;66(2):262-268.

281. Francioso L, Taurino AM, Forleo A, Siciliano P. $\mathrm{TiO}_{2}$ nanowires array fabrication and gas sensing properties. Sens Actuators B Chem. 2008; 130(1):70-76.

282. Lee JC, Park KS, Kim TG, Choi HJ, Sung YM. Controlled growth of high-quality $\mathrm{TiO}_{2}$ nanowires on sapphire and silica. Nanotechnology. 2006;17(17):4317-4321.

283. Wang ZL, Liu Y, Zhang Z, editors. Handbook of Nanophase and Nanostructured Materials. New York, NY: Kluwer Academic/Plenum; 2003.

284. Shan GB, Demopoulos GP. The synthesis of aqueous-dispersible anatase $\mathrm{TiO}_{2}$ nanoplatelets. Nanotechnology. 2010;21(2):025604.

285. Arabatzis IM, Falaras P. Synthesis of porous nanocrystalline $\mathrm{TiO}_{2}$ foam. Nano Lett. 2003;3(2):249-251.

286. Gerischer H, Lubke M. A particle size effect in the sensitization of $\mathrm{TiO}_{2}$ electrodes by a CdS deposit. J Electroanal Chem. 1986;204: 225-227.

287. Hickey SG, Riley DJ. Photoelectrochemical studies of CdS nanoparticle-modified electrodes. J Phys Chem B. 1999;103(22): 4599-4602.

288. Toyoda T, Sato J, Shen Q. Effect of sensitization by quantumsized CdS on photoacoustic and photoelectrochemical current spectra of porous $\mathrm{TiO}_{2}$ electrodes. Rev Sci Instrum. 2003;74(1): 297-299.

289. Vogel R, Pohl K, Weller H. Sensitization of highly porous, polycrystalline $\mathrm{TiO}_{2}$ electrodes by quantum sized CdS. Chem Phys Lett. 1990; 174(3-4):241-246.

290. Kohtani S, Kudo A, Sakata T. Spectral sensitization of a $\mathrm{TiO}_{2}$ semiconductor electrode by CdS microcrystals and its photoelectrochemical properties. Chem Phys Lett. 1993;206(1-4):166-170.

291. Jia H, Xu H, Hu Y, Tang Y, Zhang L. TiO_@CdS core-shell nanorods films: fabrication and dramatically enhanced photoelectrochemical properties. Electrochem Commun. 2007;9(3):354-360.

292. O'Hayre R, Nanu M, Schoonman J, Goossens A. A parametric study of $\mathrm{TiO}_{2} / \mathrm{CuInS}_{2}$ nanocomposite solar cells: how cell thickness, buffer layer thickness, and $\mathrm{TiO}_{2}$ particle size affect performance. Nanotechnology. 2007;18(5):055702.

293. Nanu M, Schoonman J, Goossens A. Inorganic nanocomposites of $\mathrm{n}$ - and p-type semiconductors: a new type of three-dimensional solar cells. Adv Mater. 2004;16(5):453-456.

294. Lenzmann F, Nanu M, Kijatkina O, Belaidi A. Substantial improvement of the photovoltaic characteristics of $\mathrm{TiO}_{2} / \mathrm{CuInS}_{2}$ interfaces by the use of recombination barrier coatings. Thin Solid Films. 2004; 451-452:639-643.

295. Nanu M, Schoonman J, Goossens A. Nanocomposite three-dimensional solar cells obtained by chemical spray deposition. Nano Lett. 2005;5(9):1716-1719.

296. O’Hayre R, Nanu M, Schoonman J, Goossens A, Wang Q, Gratzel M. The influence of $\mathrm{TiO}_{2}$ particle size in $\mathrm{TiO}_{2} / \mathrm{CuInS}_{2}$ nanocomposite solar cells. Adv Funct Mater. 2006;16(12):1566-1576.

297. Cheng L, Zhang X, Liu B, et al. Template synthesis and characterization of $\mathrm{WO}_{3} / \mathrm{TiO}_{2}$ composite nanotubes. Nanotechnology. 2005;16(8): $1341-1345$.

298. Brinley E, Seal S, Folks R, Braunstein E, Kramer L, Seal S. High efficiency $\mathrm{SiO}_{2}-\mathrm{TiO}_{2}$ hybrid sol-gel antireflective coating for infrared applications. J Vac Sci Technol A. 2006;24(4):1141-1146. 
299. Yao Y, Li G, Ciston S, Lueptow RM, Gray KA. Photoreactive TiO carbon nanotube composites: synthesis and reactivity. Environ Sci Technol. 2008;42(13):4952-4957.

300. Arana J, Dona-Rodriguez JM, Tello Rendon E, et al. TiO activation by using activated carbon as a support. Part I. Surface characterization and decantability study. Appl Catal B. 2003;44(2):161-172.

301. Arana J, Dona-Rodriguez JM, Tello Rendon E, et al. $\mathrm{TiO}_{2}$ activation by using activated carbon as a support. Part II. Photoreactivity and FTIR study. Appl Catal B. 2003;44(2):153-160.

302. Wang W, Serp P, Kalck P, Faria JL. Photocatalytic degradation of phenol on MWNT and titania composite catalysts prepared by a modified sol-gel method. Appl Catal B. 2005;56(4):305-312.

303. Lee SH, Pumprueg S, Moudgil B, Sigmund W. Inactivation of bacterial endospores by photocatalytic nanocomposites. Colloids Surf B 2005;40(2):93-98.

304. Yu Y, Yu JC, Chan CY, et al. Enhancement of adsorption and photocatalytic activity of $\mathrm{TiO}_{2}$ by using carbon nanotubes for the treatment of azo dye. Appl Catal B. 2005;61(1-2):1-11.

305. Feng W, Feng Y, Wu Z, Fujii A, Ozaki M, Yoshino K. Optical and electrical characterizations of nanocomposite film of titania adsorbed onto oxidized multiwalled carbon nanotubes. J Phys Condens Matter. 2005;17(27):4361-4368

306. Kang SZ, Cui Z, Mu J. Composite of carboxyl-modified multi-walled carbon nanotubes and $\mathrm{TiO}_{2}$ nanoparticles: preparation and photocatalytic activity. Fullerenes Nanotubes Carbon Nanostruct. 2007;15(2): 81-88.

307. Fan W, Gao L, Sun J. Anatase $\mathrm{TiO}_{2}$-coated multi-wall carbon nanotubes with the vapor phase method. J Am Ceram Soc. 2006;89(2): 731-733.

308. Jitianu A, Cacciaguerra T, Benoit R, Delpeux S, Beguin F, Bonnamy S. Synthesis and characterization of carbon nanotubes- $\mathrm{TiO}_{2}$ nanocomposites. Carbon. 2004;42(5-6):1147-1151.

309. Yu H, Zhao H, Quan X, Chen S. Preparation and characterization of aligned carbon nanotubes coated with titania nanoparticles. Chin $\mathrm{Sci}$ Bull. 2006;51(18):2294-2296.

310. Kwak SY, Kim SH, Kim SS. Hybrid organic/inorganic reverse osmosis (RO) membrane for bactericidal anti-fouling. 1. Preparation and characterization of $\mathrm{TiO}_{2}$ nanoparticle self-assembled aromatic polyamide thin-film-composite (TFC) membrane. Environ Sci Technol. 2001 35(11):2388-2394.

311. Nabid MR, Golbabaee M, Moghaddam AB, Dinarvand R, Sedghi R. Polyaniline/ $/ \mathrm{TiO}_{2}$ nanocomposite: enzymatic synthesis and electrochemical properties. Int J Electrochem Sci. 2008;3: 1117-1126.

312. Zang L, Wan M, Polyaniline/ $\mathrm{TiO}_{2}$ composite nanotubes. J Phys Chem B. 2003;107(28):6748-6753.

313. Gangopadhyay R, De A. Conducting polymer nanocomposites: a brief overview. Chem Mater. 2000;12(3):608-622.

314. Xia H, Wang Q. Ultrasonic irradiation: a novel approach to prepare conductive polyaniline/nanocrystalline titanium oxide composites. Chem Mater. 2002;14(5):2158-2165

315. Schnitzler DC, Zarbin AJG. Organic/inorganic hybrid materials formed from $\mathrm{TiO}_{2}$ nanoparticles and polyaniline. J Braz Chem Soc. 2004; 15(3):378-384

316. Fan X, Lin L, Messersmith PB. Surface-initiated polymerization from $\mathrm{TiO}_{2}$ nanoparticle surfaces through a biomimetic initiator: a new route toward polymer-matrix nanocomposites. Compos Sci Technol. 2006; 66(9):1198-1204

317. Liu Y, Wang A, Claus R. Molecular self-assembly of $\mathrm{TiO}_{2} /$ polymer nanocomposite films. J Phys Chem B. 1997;101(8):1385-1388.

318. Rizza R, Fitzmaurice D, Hearne S, et al. Self-assembly of monolayers of semiconductor nanocrystallites. Chem Mater. 1997;9(12): 2969-2982.

319. Kovtyukhova N, Ollivier PJ, Chizhik S, et al. Self-assembly of ultrathin composite $\mathrm{TiO}_{2}$ /polymer films. Thin Solid Films. 1999;337(1-2): $166-170$.
320. Bard AJ. Design of semiconductor photoelectrochemical systems for solar energy conversion. J Phys Chem. 1982;86(2):172-177.

321. Gratzel M, editor. Energy Resources Through Photochemistry and Catalysis. New York, NY: Academic Press; 1983.

322. Kalyanasundaram K, Gratzel M, Pelizzetti E. Interfacial electron transfer in colloidal metal and semiconductor dispersions and photodecomposition of water. Coord Chem Rev. 1986;69:57-125.

323. Parmon VN, Zamareav KI. Photocatalysis in energy production. In: Serpone N, Pelizzetti E, editors. Photocatalysis - Fundamentals and Applications. New York, NY: Wiley Interscience; 1989:565.

324. Pelizzetti E, Schiavello M, editors. Photochemical Conversion and Storage of Solar Energy. Dordrecht, Germany: Kluwer Academic Publishers; 1991.

325. Schiavello M, editor. Photocatalysis and Environment. Dordrecht, Germany: Kluwer Academic Publishers; 1988.

326. Ollis DF, Al-Ekabi H, editors. Photocatalytic Purification and Treatment of Water and Air. Amsterdam, The Netherlands: Elsevier; 1993.

327. Hurum DC, Agrios AG, Gray KA, Rajh T, Thurnauer MC. Explaining the enhanced photocatalytic activity of degussa p25 mixed-phase $\mathrm{TiO}_{2}$ using EPR. J Phys Chem B. 2003;107(19): 4545-4549.

328. Shankar K, Basham JI, Allam NK, et al. Recent advances in the use of $\mathrm{TiO}_{2}$ nanotube and nanowire arrays for oxidative photoelectrochemistry. J Phys Chem C. 2009;113(16):6327-6359.

329. Mauzerall D, Ballard SG. Ionization in solution by photoactivated electron transfer. Annu Rev Phys Chem. 1982;33:377-407.

330. Forster T. Transfer mechanisms of electronic excitation. Faraday Discuss Chem Soc. 1959;27:7-17.

331. Okabe H. Photochemistry of Small Molecules. New York, NY: Wiley-Interscience; 1978.

332. Gilbert A, Baggott J. Essentials of Molecular Photochemistry. Boca Raton, FL: CRC Press; 1991.

333. Fox MA, Chanon M, editors. Photoinduced Electron Transfer, Part A: Conceptual Basis. Amsterdam, The Netherlands: Elsevier; 1988.

334. Serpone N, Pelizzetti E, editors. Photocatalysis, Fundamentals and Applications. New York, NY: Wiley-Interscience; 1989.

335. Gratzel M. Heterogeneous Photochemical Electron Transfer. Boca Raton, FL: CRC Press; 1989.

336. Julliard M, Chanon M. Photoelectron-transfer catalysis: its connections with thermal and electrochemical analogs. Chem Rev. 1983;83(4): 425-506.

337. Kavarnos GJ, Turro NJ. Photosensitization by reversible electron transfer: theories, experimental evidence, and examples. Chem Rev. 1986;86(2):401-449.

338. Fox MA, Dulay MT. Heterogeneous photocatalysis. Chem Rev. 1993 93(1):341-357.

339. Kamat PV. Photochemistry on nonreactive and reactive (semiconductor) surfaces. Chem Rev. 1993;93(1):267-300.

340. Mills A, Hunte SL. An overview of semiconductor photocatalysis. J Photochem Photobiol A Chem. 1997;108(1):1-35.

341. Hoffmann MR, Martin ST, Choi W, Bahnemannt DW. Environmental applications of semiconductor photocatalysis. Chem Rev. 1995;95: 69-96.

342. Augustynski J. The role of the surface intermediates in the photoelectrochemical behavior of anatase and rutile $\mathrm{TiO}_{2}$. Electrochim Acta. 1993;38(1):43-46.

343. Fujishima A, Zhang X, Tryk DA. $\mathrm{TiO}_{2}$ photocatalysis and related surface phenomena. Surf Sci Rep. 2008;63(12):515-582.

344. Ni M, Leung MKH, Leung DY, Sumathy K. A review and recent developments in photocatalytic water splitting using $\mathrm{TiO}_{2}$ for hydrogen production. Renew Sustain Energy Rev. 2007;11(3): 401-425.

345. Kamat PV. Meeting the clean energy demand: nanostructure architectures for solar energy conversion. J Phys Chem C. 2007;111(7): 2834-2860. 
346. Nowotny J, Bak T, Nowotny MK, Sheppard LR. Titanium dioxide for solar-hydrogen. I. Functional properties. Int J Hydrogen Energy. 2007;32(14):2609-2629.

347. Nowotny J, Bak T, Nowotny MK, Sheppard LR. Titanium dioxide for solar-hydrogen. III. Kinetic effects at elevated temperatures. Int $J$ Hydrogen Energy. 2007;32(14):2644-2650.

348. Wold A. Photocatalytic properties of $\mathrm{TiO}_{2}$. Chem Mater. 1993;5(3): 280-283.

349. Mor GK, Varghese OK, Paulose M, Shankar K, Grimes CA. A review on highly ordered, vertically oriented $\mathrm{TiO}_{2}$ nanotube-arrays: fabrication, material properties, and solar energy applications. Solar Energy Mater Solar Cells. 2006;90(14):2011-2075.

350. Tachikawa T, Fujitsuka M, Majima T. Mechanistic insight into the $\mathrm{TiO}_{2}$ photocatalytic reactions: design of new photocatalysts. $J$ Phys Chem C. 2007;111(14):5259-5275.

351. Aroutiounian VM, Arakelyan VM, Shahnazaryan GE. Metal oxide photoelectrodes for hydrogen generation using solar radiation-driven water splitting. Solar Energy. 2005;78(5):581-592.

352. Gratzel M. Photoelectrochemical cells. Nature. 2001;414:338-344.

353. Murphy TW Jr. Home photovoltaic systems for physicists. Phys Today. 2008;61(7):42-47.

354. Juodkazis K, Juodkazyte J, Jelmakas E, et al. Photoelectrolysis of water: solar hydrogen - achievements and perspectives. Opt Express. 2010;18 Suppl 2:A147-A160.

355. Sato $\mathrm{S}$, White JM. Photoassisted hydrogen production from titania and water. J Phys Chem. 1981;85(5):592-594.

356. Fujishima A, Rao TN, Tryk DA. Titanium dioxide photocatalysis. J Photochem Photobiol C Photochem Rev. 2000;1(1):1-21.

357. Wrighton MS, Ginley DS, Wolczanski PT, Ellis AB, Morse DL, Linz A. Photoassisted electrolysis of water by irradiation of a titanium dioxide electrode. Proc Natl Acad Sci U S A. 1975;72(4): 1518-1522.

358. Duonghong D, Borgarello E, Graetzel M. Dynamics of light-induced water cleavage in colloidal systems. J Am Chem Soc. 1981;103(16): 4685-4690.

359. Van Hieu N, Lichtman D. Band gap radiation-induced photodesorption from polycrystalline powder surfaces of $\mathrm{SrTiO}_{3}$. J Catal. 1982;73(2): 329-336.

360. Courbon H, Formenti M, Pichat P. Study of oxygen isotopic exchange over ultraviolet irradiated anatase samples and comparison with the photooxidation of isobutane into acetone. J Phys Chem. 1977;81(6): $550-554$.

361. Bickley RI, Munuera G, Stone FS. Photoadsorption and photocatalysis at rutile surfaces: II. Photocatalytic oxidation of isopropanol. J Catal. 1973;31(3):398-407.

362. Munuera G, Rives-Amau V, Saucedo A. Photo-adsorption and photodesorption of oxygen on highly hydroxylated $\mathrm{TiO}_{2}$ surfaces. Part 1. Role of hydroxyl groups in photo-adsorption. $J$ Chem Soc Faraday Trans 1. 1979;75:736-747.

363. Anpo M, Kubokawa Y, Fujii T, Suzuki S. Quantum chemical and molecular oxygen-18 tracer studies of the activation of oxygen in photocatalytic oxidation reactions. $J$ Phys Chem. 1984;88(12): $2572-2575$.

364. Lu G, Linsebigler A, Yates JT Jr. The photochemical identification of two chemisorption states for molecular oxygen on $\mathrm{TiO}_{2}(110)$. J Chem Phys. 1995;102(7):3005-3008.

365. Yanagisawa Y, Ota Y. Thermal and photo-stimulated desorption of chemisorbed oxygen molecules from titanium dioxide surfaces. Surf Sci Lett. 1991;254(1-3):L433-L436.

366. Funk S, Hokkanen B, Burghaus U, Ghicov A, Schmuki P. Unexpected adsorption of oxygen on $\mathrm{TiO}_{2}$ nanotube arrays: influence of crystal structure. Nano Lett. 2007;7(4):1091-1094.

367. Inderwildi OR, Kraft M. Adsorption, diffusion and desorption of chlorine on and from rutile $\mathrm{TiO}_{2}\{110\}$ : a theoretical investigation. Chemphyschem. 2007;8(3):444-451.

368. Uner D, Tapan NA, Özen İ, Üner M. Oxygen adsorption on $\mathrm{Pt} / \mathrm{TiO}_{2}$ catalysts. Appl Catal A. 2003;251(2):225-234.
369. Kimmel GA, Petrik NG. Tetraoxygen on reduced $\mathrm{TiO}_{2}(110)$ : oxygen adsorption and reactions with bridging oxygen vacancies. Phys Rev Lett. 2008;100(19):196102.

370. Petrik NG, Kimmel GA. Off-normal $\mathrm{CO}_{2}$ desorption from the photooxidation of $\mathrm{CO}$ on reduced $\mathrm{TiO}_{2}(110)$. J Phys Chem Lett. 2010;1(17):2508-2513.

371. Ajo HM, Bondzie VA, Campbell CT. Propene adsorption on gold particles on $\mathrm{TiO}_{2}(110)$. Catal Lett. 2002;78(1-4):359-368.

372. Chen MT, Lin YF, Liao LF, Lien CF, Lin JL. Adsorption and reactions of $\mathrm{CH}_{2} \mathrm{Br}_{2}$ on $\mathrm{TiO}_{2}$ : effects of $\mathrm{H}_{2} \mathrm{O}$ and $\mathrm{O}_{2}$. Int $J$ Photoenergy. 2004;6(1):35-41.

373. Lee J, Zhang Z, Yates JT Jr. Electron-stimulated positive-ion desorption caused by charge transfer from adsorbate to substrate: oxygen adsorbed on $\mathrm{TiO}_{2}$ (110). Phys Rev B. 2009;79(8): 081408.1-081408.4.

374. Schrauzer GN, Guth TD. Photocatalytic reactions. 1. Photolysis of water and photoreduction of nitrogen on titanium dioxide. J Am Chem Soc. 1977;99(22):7189-7193.

375. Bickley RI, Jayanty RKM, Navio JA, Real C, Macias M. Photooxidative fixation of molecular nitrogen on $\mathrm{TiO}_{2}$ (rutile) surfaces: the nature of the adsorbed nitrogen-containing species. Surf Sci. 1991; 251-252:1052-1056.

376. Seiji Y, Taro O, Tsunehiro T. Ammonia photo-oxidation over $\mathrm{TiO}_{2}$ photo-catalyst. Catalysts Catal. 2006;48(2):110-112.

377. Inoue T, Fujishima A, Konishi S, et al. Photoelectrocatalytic reduction of carbon dioxide in aqueous suspensions of semiconductor powders. Nature. 1979;277(22):637-638.

378. Hirano K, Inoue K, Yatsu T. Photocatalysed reduction of $\mathrm{CO}_{2}$ in aqueous $\mathrm{TiO}_{2}$ suspension mixed with copper powder. $J$ Photochem Photobiol A: Chem. 1992;64:255-258.

379. Tennakone K. Photoreduction of carbonic acid by mercury coated n-titanium dioxide. Sol Energy Mater. 1984;10(2):235-238.

380. Rophael WM, Malati MA. The photocatalysed reduction of aqueous sodium carbonate to carbon using platinised titania. J Chem Soc Chem Commun. 1987:1418-1420.

381. Ishitani O, Inoue C, Suzuki Y, Ibusuki T. Photocatalytic reduction of carbon dioxide to methane and acetic acid by an aqueous suspension of metal-deposited $\mathrm{TiO}_{2}$.J Photochem Photobiol A Chem. 1993;72(3): 269-271.

382. Woolerton TW, Sheard S, Reisner E, Pierce E, Ragsdale SW, Armstrong FA. Efficient and clean photoreduction of $\mathrm{CO}_{2}$ to $\mathrm{CO}$ by enzyme-modified $\mathrm{TiO}_{2}$ nanoparticles using visible light. $J$ Am Chem Soc. 2010;132(7):2132-2133.

383. Wang C, Thompson RL, Baltrus J, Matranga C. Visible light photoreduction of $\mathrm{CO}_{2}$ using $\mathrm{CdSe} / \mathrm{Pt} / \mathrm{TiO}_{2}$ heterostructured catalysts. $J$ Phys Chem Lett. 2010;1(1):48-53.

384. Chen L, Graham ME, Li G, Gentner DR, Dimitrijevic NM, Gray KA. Photoreduction of $\mathrm{CO}_{2}$ by $\mathrm{TiO}_{2}$ nanocomposites synthesized through reactive direct current magnetron sputter deposition. Thin Solid Films. 2009;517(19):5641-5645.

385. Cueto LF, Martínez GT, Zavala G, Sánchez EM. Surface characterization and $\mathrm{CO}_{2}$ reduction using electrodeposited silver particles over $\mathrm{TiO}_{2}$ thin film. $J$ Nano Res. 2010;9:89-100.

386. Draper RB, Fox MA. Titanium dioxide photosensitized reactions studied by diffuse reflectance flash photolysis in aqueous suspensions of $\mathrm{TiO}_{2}$ powder. Langmuir. 1990;6(8):1396-1402.

387. Fitzmaurice DJ, Eschle M, Frei H, Moser J. Time-resolved rise of iodine molecule $\left(\mathrm{I}^{-}\right)$upon oxidation of iodide at aqueous titania colloid. J Phys Chem. 1993;97(15):3806-3812.

388. O'Regan B, Gratzel M. A low-cost, high-efficiency solar cell based on dye-sensitized colloidal $\mathrm{TiO}_{2}$ films. Nature. 1991;353:737-740.

389. Henderson MA. Photooxidation of acetone on $\mathrm{TiO}_{2}(110)$ : conversion to acetate via methyl radical ejection. $J$ Phys Chem $B$. 2005;109(24):12062-12070.

390. De Jongh PE, Vanmaekelbergh D. Trap-limited electronic transport in assemblies of nanometer-size $\mathrm{TiO}_{2}$ particles. Phys Rev Lett. 1996; 77(16):3427-3430. 
391. Zaleska A. Doped-TiO : a review. Recent Patents Eng. 2008;2: 157-164.

392. Dvoranová D, Brezová V, Mazúr M, Malati MA. Investigations of metal-doped titanium dioxide photocatalysts. Appl Catal B Environ. 2002;37(2):91-105.

393. Umebayashi T, Yamaki T, Itoh H, Asak K. Analysis of electronic structures of $3 \mathrm{~d}$ transition metal-doped $\mathrm{TiO}_{2}$ based on band calculations. J Phys Chem Solids. 2002;63(10):1909-1920.

394. Davydov L, Reddy EP, France P, Smirniotis PG. Transition metal-substituted titania-loaded MCM-41 as photocatalysts for the degradation of aqueous organics in visible light. J Catal. 2001;203(1):157-167.

395. Anpo M. Use of visible light. Second-generation titanium dioxide photocatalysts prepared by the application of an advanced metal ion-implantation method. Pure Appl Chem. 2000;72(9):1787-1792.

396. Fuerte A, Hernández-Alonso MD, Maira AJ, et al. Visible light-activated nanosized doped- $\mathrm{TiO}_{2}$ photocatalysts. Chem Commun. 2001; 24:2718-2719

397. Yamashita H, Harada M, Misaka J, et al. Application of ion beam techniques for preparation of metal ion-implanted $\mathrm{TiO}_{2}$ thin film photocatalyst available under visible light irradiation: metal ion-implantation and ionized cluster beam method. $J$ Synchrotron Radiat. 2001;8(Pt 2):569-571

398. Wilke K, Breuer HD. The influence of transition metal doping on the physical and photocatalytic properties of titania. J Photochem Photobiol A Chem. 1999;121(1):49-53.

399. Wilke K, Breuer HD. Transition metal doped titania: physical properties and photocatalytic behaviour. Z Phys Chem. 1999;213:135-140.

400. Hong NH, Sakai J, Prellier W, Ruyter A. Room temperature ferromagnetism in laser ablated transition-metal-doped $\mathrm{TiO}_{2}$ thin films on various types of substrates. J Phys D Appl Phys. 2005;38(6): 816-821.

401. Narayanan BN, Koodathil R, Gangadharan T, Yaakob Z, Saidu FK, Chandralayam S. Preparation and characterization of exfoliated polyaniline/montmorillonite nanocomposites. Mater Sci Eng B. 2010;168(1-3):242-244.

402. Xu AW, Gao Y, Liu HQ. The preparation, characterization, and their photocatalytic activities of rare-earth-doped $\mathrm{TiO}_{2}$ nanoparticles. $J$ Catal. 2002;207(2):151-157.

403. Moon J, Takagi H, Fujishiro Y, Awano M. Preparation and characterization of the Sb-doped $\mathrm{TiO}_{2}$ photocatalysts. J Mater Sci. 2001;36(4): 949-955.

404. Li J, Zeng HC. Hollowing Sn-doped $\mathrm{TiO}_{2}$ nanospheres via Ostwald ripening. J Am Chem Soc. 2007;129(51):15839-15847.

405. Shen Y, Xiong T, Li T, Yang K. Tungsten and nitrogen co-doped $\mathrm{TiO}_{2}$ nano-powders with strong visible light response. Appl Catal B. 2008; 83(3-4):177-185

406. Asahi R, Morikawa T, Ohwaki T, Aoki K, Taga Y. Visible-light photocatalysis in nitrogen-doped titanium oxides. Science. 2001; 293(5528):269-271.

407. Ihara T, Miyoshi M, Iriyama Y, Matsumoto O, Sugihara S. Visiblelight-active titanium oxide photocatalyst realized by an oxygen deficient structure and by nitrogen doping. Appl Catal B Environ. 2003; 42(4):403-409.

408. Sakthivel S, Kisch H. Photocatalytic and photoelectrochemical properties of nitrogen-doped titanium dioxide. Chemphyschem. 2003;4(5): 487-490.

409. Irie $\mathrm{H}$, Watanabe $\mathrm{Y}$, Hashimoto $\mathrm{K}$. Carbon-doped anatase $\mathrm{TiO}_{2}$ powders as a visible-light sensitive photocatalyst. Chem Lett. 2003;32(8): 772-773.

410. Park JH, Kim S, Bard AJ. Novel carbon-doped $\mathrm{TiO}_{2}$ nanotube arrays with high aspect ratios for efficient solar water splitting. Nano Lett. 2006;6(1):24-28.

411. Yamaki T, Umebayashi T, Sumita T, et al. Fluorine-doping in titanium dioxide by ion implantation technique. Nucl Instrum Methods Phys Res Sec B. 2003;206:254-258.

412. Ohno T, Mitsui T, Matsumura M. Photocatalytic activity of S-doped $\mathrm{TiO}_{2}$ photocatalyst under visible light. Chem Lett. 2003;32(4):364-365.
413. Liu Y, Chen X, Li J, Burda C. Photocatalytic degradation of azo dyes by nitrogen-doped $\mathrm{TiO}_{2}$ nanocatalysts. Chemosphere. 2005;61(1): $11-18$.

414. Yu JC, Zhang L, Zheng Z, Zhao J. Synthesis and characterization of phosphated mesoporous titanium dioxide with high photocatalytic activity. Chem Mater. 2003;15(11):2280-2286.

415. Lei L, Su Y, Zhou M, Zhang X, Chen X. Fabrication of multi-nonmetal-doped $\mathrm{TiO}_{2}$ nanotubes by anodization in mixed acid electrolyte. Mater Res Bull. 2007;42(12):2230-2236.

416. Kang IC, Zhang Q, Yin S, Stao T, Saito F. Preparation of a visible sensitive carbon doped $\mathrm{TiO}_{2}$ photo-catalyst by grinding $\mathrm{TiO}_{2}$ with ethanol and heating treatment. Appl Catal B. 2008;80(1-2): 81-87.

417. Bettinelli M, Dallacasa V, Falcomer D, et al. Photocatalytic activity of $\mathrm{TiO}_{2}$ doped with boron and vanadium. J Hazard Mater. 2007;146(3): 529-534.

418. Liu C, Tang X, Mo C, Qiang Z. Characterization and activity of visible-light-driven $\mathrm{TiO}_{2}$ photocatalyst codoped with nitrogen and cerium. J Solid State Chem. 2008;181(4):913-919.

419. Kim SW, Khan R, Kim TJ, Kim WJ. Synthesis, characterization, and application of $\mathrm{Zr}, \mathrm{S}$ co-doped $\mathrm{TiO}_{2}$ as visible-light active photocatalyst. Bull Korean Chem Soc. 2008;29(6):1217-1223.

420. Sakthivel S, Janczarek M, Kisch H. Visible light activity and photoelectrochemical properties of nitrogen-doped $\mathrm{TiO}_{2}$. J Phys Chem B. 2004;108(50):19384-19387.

421. Shankar K, Tep KC, Mor GK, et al. An electrochemical strategy to incorporate nitrogen in nanostructured $\mathrm{TiO}_{2}$ thin films: modification of bandgap and photoelectrochemical properties. J Phys D Appl Phys. 2006;39(11):2361-2366

422. Wu ZB, Dong F, Zhao WR, Guo S. Visible light induced electron transfer process over nitrogen doped $\mathrm{TiO}_{2}$ nanocrystals prepared by oxidation of titanium nitride. $J$ Hazard Mater. 2008;157(1): $57-63$.

423. Lindgren T, Lu J, Hoel A, Granqvist CG, Torres GR, Lindquist SE. Photo electrochemical study of sputtered nitrogen-doped titanium dioxide thin films in aqueous electrolyte. Solar Energy Mater Solar Cells. 2004;84(1-4):145-157.

424. Lindgren T, Mwabora JM, Avendano E, et al. Photoelectrochemical and optical properties of nitrogen doped titanium dioxide films prepared by reactive DC magnetron sputtering. J Phys Chem B. 2003; 107(24):5709-5716.

425. Diwald O, Thompson TL, Goralski EG, Walck SD, Yates JT Jr. The effect of nitrogen ion implantation on the photoactivity of $\mathrm{TiO}_{2}$ rutile single crystals. J Phys Chem B. 2004;108(1):52-57.

426. Serpone N. Is the band gap of pristine $\mathrm{TiO}_{2}$ narrowed by anion- and cation-doping of titanium dioxide in second-generation photocatalysts? J Phys Chem B. 2006;110(48):24287-24293.

427. Wang $\mathrm{H}$, Lewis JP. Second-generation photocatalytic materials: aniondoped $\mathrm{TiO}_{2}$. J Phys Condens Matter. 2006;18(2):421-434.

428. Zhao W, Ma W, Chen C, Zhao J, Shuai Z. Efficient degradation of toxic organic pollutants with $\mathrm{Ni}_{2} \mathrm{O}_{3} / \mathrm{TiO}_{2-x} \mathrm{~B}$ under visible irradiation. $J$ Am Chem Soc. 2004;126(15):4782-4783.

429. Gao B, Ma Y, Cao Y, Yang W, Yao J. Great enhancement of photocatalytic activity of nitrogen-doped titania by coupling with tungsten oxide. J Phys Chem B. 2006;110(29):14391-14397.

430. Ohno T, Miyamoto Z, Nishijima K, et al. Sensitization of photocatalytic activity of $\mathrm{S}$ - or $\mathrm{N}$-doped $\mathrm{TiO}_{2}$ particles by adsorbing $\mathrm{Fe}^{3+}$ cations. Appl Catal A. 2006;302(1):62-68.

431. Morikawa T, Irokawa Y, Ohwaki T. Enhanced photocatalytic activity of $\mathrm{TiO}_{2-x} \mathrm{~N}_{x}$ loaded with copper ions under visible light irradiation. Appl Catal A. 2006;314(1):123-127.

432. Hirai T, Suzuki K, Komasawa I. Preparation and photocatalytic properties of composite CdS nanoparticles-titanium dioxide particles. J Colloid Interface Sci. 2001;244(2):262-265.

433. Lettmann C, Hinrichs H, Maier WF. Combinatorial discovery of new photocatalysts for water purification with visible light. Angew Chem Int Ed Engl. 2001;40(17):3160-3164. 
434. Liu B, Zhao X, Zhang N, Zhao Q, He X, Feng J. Photocatalytic mechanism of $\mathrm{TiO}_{2}-\mathrm{CeO}_{2}$ films prepared by magnetron sputtering under UV and visible light. Surf Sci. 2005;595(1-3):203-211.

435. Grasso C, Burgelman M. Theoretical study on the effect of an intermediate layer in CIS-based ETA-solar cells. Thin Solid Films. 2004; 451-452:156-159.

436. Papp J, Soled S, Dwight K, Wold A. Surface acidity and photocatalytic activity of $\mathrm{TiO}_{2}, \mathrm{WO}_{3} / \mathrm{TiO}_{2}$, and $\mathrm{MoO}_{3} / \mathrm{TiO}_{2}$ photocatalysts. Chem Mater. 1994;6(4):496-500.

437. Mane RS, Lee WJ, Pathan HM, Han SH. Nanocrystalline $\mathrm{TiO}_{2} / \mathrm{ZnO}$ thin films: fabrication and application to dye-sensitized solar cells. J Phys Chem B. 2005;109(51):24254-24259.

438. Liao DL, Badour CA, Liao BQ. Preparation of nanosized $\mathrm{TiO}_{2} / \mathrm{ZnO}$ composite catalyst and its photocatalytic activity for degradation of methyl orange. J Photochem Photobiol A: Chem. 2008;194(1): $11-19$.

439. Kansal SK, Singh M, Sud D. Studies on $\mathrm{TiO}_{2} / \mathrm{ZnO}$ photocatalysed degradation of lignin. J Hazard Mater. 2008;153(1-2):412-417.

440. Jiang Y, Sun Y, Liu H, Zhu F, Yin H. Solar photocatalytic decolorization of C.I. Basic Blue 41 in an aqueous suspension of $\mathrm{TiO}_{2}-\mathrm{ZnO}$. Dyes Pigments. 2008;78(1):77-83.

441. Tada H, Hattori A, Tokihisa Y, Imai K, Tohge N, Ito S. A patterned$\mathrm{TiO}_{2} / \mathrm{SnO}_{2}$ bilayer type photocatalyst. J Phys Chem B. 2000;104(19): 4585-4587.

442. Liu Z, Sun DD, Guo P, Leckie JO. An efficient bicomponent $\mathrm{TiO}_{2} / \mathrm{SnO}_{2}$ nanofiber photocatalyst fabricated by electrospinning with a side-byside dual spinneret method. Nano Lett. 2007;7(4):1081-1085.

443. Wang $\mathrm{C}, \mathrm{Xu} \mathrm{BQ}$, Wang $\mathrm{X}$, Zhao J. Preparation and photocatalytic activity of $\mathrm{ZnO} / \mathrm{TiO}_{2} / \mathrm{SnO}_{2}$ mixture. J Solid State Chem. 2005;178(11): 3500-3506.

444. Lin CF, Wu CH, Onn ZN. Degradation of 4-chlorophenol in $\mathrm{TiO}_{2}$, $\mathrm{WO}_{3}, \mathrm{SnO}_{2}, \mathrm{TiO}_{2} / \mathrm{WO}_{3}$ and $\mathrm{TiO}_{2} / \mathrm{SnO}_{2}$ systems. J Hazard Mater. 2008; 154(1-3):1033-1039.

445. Robel I, Bunker BA, Kamat PV. Single-walled carbon nanotube-CdS nanocomposites as light-harvesting assemblies: photoinduced chargetransfer interactions. Adv Mater. 2005;17(20):2458-2463.

446. Grätzel M. Dye-sensitized solar cells. J Photochem Photobiol C Photochem Rev. 2003;4:145-153.

447. Kubo W, Murakoshi K, Kitamura T, et al. Quasi-solid-state dyesensitized tio $_{2}$ solar cells: effective charge transport in mesoporous space filled with gel electrolytes containing iodide and iodine. J Phys Chem B. 2001;105(51):12809-12815.

448. Bisquert J, Cahen D, Hodes G, Rühle S, Zaban R. Physical chemical principles of photovoltaic conversion with nanoparticulate, mesoporous dye-sensitized solar cells. J Phys Chem B. 2004;108(24): 8106-8118.

449. Smestad GP. Education and solar conversion: demonstrating electron transfer. Sol Energy Mater Solar Cells. 1998;55(1-2):157-178.

450. Nakade S, Saito Y, Kubo W, Kitamura T, Wada Y, Yanagida S. Influence of $\mathrm{TiO}_{2}$ nanoparticle size on electron diffusion and recombination in dye-sensitized $\mathrm{TiO}_{2}$ solar cells. J Phys Chem B. 2003;107(33): 8607-8611.

451. Nakade S, Matsuda M, Kambe S, et al. Dependence of $\mathrm{TiO}_{2}$ nanoparticle preparation methods and annealing temperature on the efficiency of dye-sensitized solar cells. J Phys Chem B. 2002;106(39): 10004-10010.

452. Sodergren S, Hagfeldt A, Olsson J, Lindquist SE. Theoretical models for the action spectrum and the current-voltage characteristics of microporous semiconductor films in photoelectrochemical cells. J Phys Chem. 1994;98(21):5552-5556.

453. Cao F, Oskam G, Meyer GJ, Searson PC. Electron transport in porous nanocrystalline $\mathrm{TiO}_{2}$. J Phys Chem. 1996;100(42):17021-17027.

454. Solbrand A, Lindstrom H, Rensmo H, Hagfelddt A, Lindquist SE. Electron transport in the nanostructured $\mathrm{TiO}_{2}$-electrolyte system studied with time-resolved photocurrents. J Phys Chem B. 1997; 101(14):2514-2518.
455. Kabra K, Chaudhury R, Sawney RL. Treatment of hazardous organic and inorganic compounds through aqueous-phase photocatalysis: a review. Ind Eng Chem Res. 2004;43(24):7683-7696.

456. Hermann JM. Heterogeneous photocatalysis: state of the art and present applications. Top Catal. 2005;34(1-4):49-65.

457. Melemeni M, Stamatakis D, Xekoukoulotakis NP, Mantzavinos D, Kalogerakis N. Disinfection of municipal wastewater by $\mathrm{TiO}_{2}$ photocatalysis with UV-A, visible and solar irradiation and BDD electrolysis. Global NEST J. 2009;11(3):357-363.

458. Palmisano G, Augugliaro V, Pagliaro M, Palmisano L. Photocatalysis: a promising route for 21 st century organic chemistry. Chem Commun (Camb). 2007;(33):3425-3437.

459. Ollis DF. Photocatalytic purification and remediation of contaminated air and water. C R Acad Sci Paris Chem. 2000;3(6):405-411.

460. McCullagh C, Robertson JMC, Bahnemann DW, Robertson PKJ. The application of $\mathrm{TiO}_{2}$ photocatalysis for disinfection of water contaminated with pathogenic micro-organisms: a review. Res Chem Intermed. 2007;33(3-5):359-375.

461. Carp O, Huisman CL, Reller A. Photoinduced reactivity of titanium dioxide. Prog Solid State Chem. 2004;32(1-2):33-177.

462. Saint Gobain Glass Co. Ltd. Available from: www.selfcleaningglass. com. Accessed 2010 Jun 1.

463. Nippon Sheet Glass Co. Ltd. Website. Available from: http://www. nsg.co.jp/en/. Accessed 2010 Jun 1.

464. Han W, Wang YD, Zheng YF. In vitro biocompatibility study of nano $\mathrm{TiO}_{2}$ materials. Adv Mater Res. 2008;47-50:1438-1441.

465. Carbone R, Marangi I, Zanardi A, et al. Biocompatibility of clusterassembled nanostructured $\mathrm{TiO}$, with primary and cancer cells. Biomaterials. 2006;27(17):3221-3229.

466. Karpagavalli R, Zhou A, Chellamuthu P, Nguyen K. Corrosion behavior and biocompatibility of nanostructured $\mathrm{TiO}_{2}$ film on Ti6Al4V. J Biomed Mater Res A. 2007;83(4):1087-1095.

467. Cui C, Liu H, Li Y, et al. Fabrication and biocompatibility of nano$\mathrm{TiO}_{2}$ /titanium alloys biomaterials. Mater Lett. 2005;59(24-25): 3144-3148.

468. Wei J, Chen QZ, Stevens MM, Roether JA, Boccaccini AR. Biocompatibility and bioactivity of PDLLA/TiO and PDLLA/TiO $/$ Bioglass $^{\mathbb{R}}$ nanocomposites. Mater Sci Eng C. 2008;28(1):1-10.

469. Yuan Q, He G, Tan Z, et al. Biocompatibility of nano- $\mathrm{TiO}_{2} / \mathrm{HA}$ bioceramic coating for nerve regeneration around dental implants. Key Eng Mater. 2007;330-332:1393-1396.

470. Abrahams SC, Bernstein JL. Rutile: normal probability plot analysis and accurate measurement of crystal structure. J Chem Phys. 1971; 55:3206-3211.

471. Pascual J, Camassel J, Mathieu H. Fine structure in the intrinsic absorption edge of $\mathrm{TiO}_{2}$. Phys Rev B. 1978;18(10):5606-5614.

472. Mathieu H, Pascual J, Camassel J. Uniaxial stress dependence of the direct-forbidden and indirect-allowed transitions of $\mathrm{TiO}_{2}$. Phys Rev B. 1978;18:6920-6929.

473. Eucken A, Dannöhl W. Die thermisce Ausdehnung einiger Alkalihalogenide and Metalle bei hohen Temperaturen. Z Elektrochem. 1934; 40:814-821.

474. Eucken A, Büchner A. Die Dielecrizitatskonstante schwach polare Kristalle and ihre Temperaturabhangigkeit. Z Phys Chem B. 1935; 27:321-349.

475. Roberts S. Dielectric constants and polarizabilities of ions in simple crystals and barium titanate. Phys Rev. 1949;76(8):1215-1220.

476. Poumellec B, Marucco JF, Lagnel F. Electron transport in $\mathrm{TiO}_{2-x}$ at intermediate temperatures $300 \mathrm{~K}<T<1500 \mathrm{~K}$. Phys Stat Sol A. 1985;89(1):375-382.

477. Acket GA, Volger J. On the electron mobility and the donor centers in reduced and lithium-doped rutile $\left(\mathrm{TiO}_{2}\right)$. Physica. 1966;32(10): $1680-1692$.

478. Jellison GE Jr, Boatner LA, Budai JD, Jeong B-S, Norton DP. Spectroscopic ellipsometry of thin film and bulk anatase $\left(\mathrm{TiO}_{2}\right)$. J Appl Phys. 2003;93(12):9537-9541. 
479. Jaeger CD, Bard AJ. Spin trapping and electron spin resonance detection of radical intermediates in the photodecomposition of water at titanium dioxide particulate systems. J Phys Chem. 1979; 83:3146-3152.

480. Yuan ZH, Jia JH, Zhang LD. Influence of co-doping of Zn(II) + Fe(III) on the photocatalytic activity of $\mathrm{TiO}_{2}$ for phenol degradation. Mater Chem Phys. 2002;73(2-3):323-326.

481. Kim DH, Woo SI, Moon SH, et al. Effect of Co/Fe co-doping in $\mathrm{TiO}_{2}$ rutile prepared by solid state reaction. Solid State Commun. 2005; 136(9-10):554-558.

482. Luo H, Takata T, Lee Y, Zhao J, Domen K, Yan Y. Photocatalytic activity enhancing for titanium dioxide by co-doping with bromine and chlorine. Chem Mater. 2004;16(5):846-849.

483. Cong Y, Zhang J, Chen F, Anpo M, He D. Preparation, photocatalytic activity, and mechanism of nano- $\mathrm{TiO}_{2}$ co-doped with nitrogen and iron (III). J Phys Chem C. 2007;111(28):10618-10623.
484. Chen D, Jiang Z, Geng J, Wang Q, Yang D. Carbon and nitrogen co-doped $\mathrm{TiO}_{2}$ with enhanced visible-light photocatalytic activity Ind Eng Chem Res. 2007;46(9):2741-2746.

485. Shi JW, Zheng JT, Hu Y, Zhao YC. Influence of $\mathrm{Fe}^{3+}$ and $\mathrm{Ho}^{3+}$ co-doping on the photocatalytic activity of $\mathrm{TiO}_{2}$. Mater Chem Phys. 2007;106(2-3):247-249.

486. Gu DE, Yang BC, Hu YD. V and N co-doped nanocrystal anatase $\mathrm{TiO}_{2}$ photocatalysts with enhanced photocatalytic activity under visible light irradiation. Catal Commun. 2008;9(6):1472-1476.

487. Obata K, Irie H, Hashimoto K. Enhanced photocatalytic activities of Ta, N co-doped $\mathrm{TiO}_{2}$ thin films under visible light. Chem Phys. 2007; 339(1-3):124-132.
Nanotechnology, Science and Applications

\section{Publish your work in this journal}

Nanotechnology, Science and Applications is an international, peerreviewed, open access journal that focuses on the science of nanotechnology in a wide range of industrial and academic applications. It is characterized by the rapid reporting across all sectors, including engineering, optics, bio-medicine, cosmetics, textiles, resource sustainability

\section{Dovepress}

and science. Applied research into nano-materials, particles, nanostructures and fabrication, diagnostics and analytics, drug delivery and toxicology constitute the primary direction of the journal. The manuscript management system is completely online and includes a very quick and fair peer-review system, which is all easy to use.

\footnotetext{
Submit your manuscript here: http://www.dovepress.com/nanotechnology-science-and-applications-journal
} 